\title{
CONTRIBUIÇÃO AO ESTUDO DO DIFERIMENTO NA LEGISLAÇÃO PAULISTA DO ICMS
}

Dissertação apresentada com o propósito de atender exigência para obtenção de título de Mestre em Direito Econômico e Financeiro. Orientação: Professor Doutor GERD WILlI ROTHMANN.

Faculdade de Direito da Universidade de São PaUlo

São Paulo 
Banca Examinadora

São Paulo,

de

de 2011 


\section{R E S U M O}

O presente estudo volta sua atenção para o diferimento constante da legislação paulista do Imposto sobre Operações Relativas à Circulação de Mercadorias e sobre Prestação de Serviços de Transporte Interestadual e Intermunicipal e de Comunicação ICMS, observados os limites que se tratou de estabelecer de modo apropriadamente nítido.

Examinados o pertinente plexo normativo, doutrina e jurisprudência, cuidou-se de formular conjecturas acerca do conceito e da natureza jurídica do diferimento constante do atual regulamento paulista do ICMS.

$\mathrm{Na}$ sequência, tratou-se de analisar espécies nas quais o emprego do aludido diferimento, por parte do Poder Executivo, resultou em alargar o conjunto de hipóteses de substituição tributária fixado pelo Poder Legislativo.

Examinou-se, em seguida, situações particulares nas quais se afigura patente o abandono da praticabilidade e da comodidade como matrizes inspiradoras do diferimento.

Passo seguinte, tratou-se de enumerar casos nos quais patente a inobservância do princípio da clareza na elaboração de textos normativos respeitantes ao diferimento.

Por derradeiro, cuidou-se de registrar observações acerca dos reflexos do diferimento constante da legislação paulista do ICMS para o lado da concorrência, bem assim a respeito de seu emprego com o fim de conceder benefícios fiscais.

Palavras-chaves: ICMS - diferimento - lançamento. 


\section{R É S U M É}

Cette étude se penche sur le différé qui intègre la législation de l'État de São Paulo concernant "l'Impôt sur Opérations Relatives à la Circulation de Marchandises et sur Prestation de Services de Transport Inter-États et Inter-Municipal et de Communication" ICMS, dans les limites ici clairement établies.

Après l'examen du plexus normatif pertinent, de la doctrine et de la jurisprudence, nous avons pris soin de formuler des conjectures sur le concept et sur la nature juridique du différé qui, au sein du Règlement de l'ICMS en vigueur à São Paulo, se nomme princípio da clareza.

Par la suite, nous avons examiné des cas concrets où la mise en place du différé par le Pouvoir Exécutif a élargi l'ensemble des hypothèses de substitution fiscale fixé par le Pouvoir Législatif.

Puis, nous avons examiné des situations particulières qui illustrent l'abandon de la praticabilité et de la commodité comme sources d'inspiration du différé.

Subséquemment, nous avons énuméré des cas concrets qui révèlent la violation du principe de la clarté dans la rédaction des textes normatifs relatifs au différé.

Enfin, nous avons pris soin d'énoncer des observations au sujet des reflets du différé sur la concurrence, ainsi comme sa mise en application dans le but d'accorder des avantages fiscaux.

Mots-clés: ICMS - différé. 


\section{LISTA DE SIGLAS E ABREVIATURAS}

A.

AA.

al.

art.

arts.

CADE

CAT

CF de 1988

CONFAZ

Constituição Paulista

Convênio ICM n ${ }^{\circ}$ 66/88

CT-SP

CTN

Dec.

g. $\mathrm{n}$.

ICM

ICMS

inc.

incs.

IVC
Autor, ou Autora

Autores, ou Autoras

Alínea

Artigo

Artigos

Conselho Administrativo de Defesa Econômica

Coordenadoria da Administração Tributária da Secretaria da Fazenda do Estado de São Paulo

Constituição Federal de 5 de outubro de 1988

Conselho Nacional de Política Fazendária

Constituição do Estado de São Paulo, de 5 de outubro de 1989

Convênio ICM nº66, de 14 de dezembro de 1988

Consultoria Tributária da Secretaria da Fazenda do Estado de São Paulo

Código Tributário Nacional - Lei $\mathrm{n}^{\circ} 5.172$, de 25 de outubro de 1966

Decreto

Grifo nosso

Imposto sobre Operações Relativas à Circulação de Mercadorias

Imposto sobre Operações Relativas a Circulação de Mercadoria e sobre Prestações de Serviços de Transporte Interestadual e Intermunicipal e de Comunicação

Inciso

Incisos

Imposto sobre Vendas e Consignações 


\begin{tabular}{|c|c|}
\hline $\mathrm{LC} \mathrm{n}^{\mathrm{o}} 24 / 75$ & Lei Complementar $\mathrm{n}^{\circ} 24$, de 7 de janeiro de 1975 \\
\hline $\mathrm{LC} \mathrm{n}^{\circ} 87 / 96$ & Lei Complementar nº 87, de 13 de setembro de 1996 \\
\hline Lei $n^{\circ} 6.374 / 89$ & $\begin{array}{l}\text { Lei Ordinária do Estado de São Paulo n }{ }^{\circ} 6.374 \text {, de } 1^{\circ} \\
\text { de março de } 1989\end{array}$ \\
\hline Lei $n^{\circ} 8.137 / 90$ & Lei Federal no 8.137, de 27 de dezembro de 1990 \\
\hline Lei $n^{\circ} 8.884 / 94$ & Lei Federal no 8.884, de 11 de junho de 1994 \\
\hline Lei $n^{\circ} 10.177 / 98$ & $\begin{array}{l}\text { Lei Ordinária do Estado de São Paulo n }{ }^{\circ} 10.177 \text {, de } 30 \\
\text { de dezembro de } 1998\end{array}$ \\
\hline $\mathrm{RE}$ & Recurso Extraordinário \\
\hline REsp & Recurso Especial \\
\hline RICMS/00 & $\begin{array}{l}\text { Regulamento paulista do ICMS, aprovado pelo } \\
\text { Decreto } \mathrm{n}^{\circ} 45.490 \text {, de } 30 \text { de novembro de } 2000\end{array}$ \\
\hline Rp. & Representação \\
\hline ss. & Seguintes \\
\hline STF & Supremo Tribunal Federal \\
\hline STJ & Superior Tribunal de Justiça \\
\hline TIT & $\begin{array}{l}\text { Tribunal de Impostos e Taxas da Secretaria da } \\
\text { Fazenda do Estado de São Paulo }\end{array}$ \\
\hline v.u. & Votação unânime \\
\hline$\S$ & Parágrafo \\
\hline
\end{tabular}




\section{Í N D I C E S I S T E M Á T I C O}

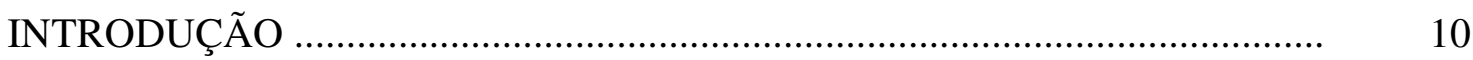

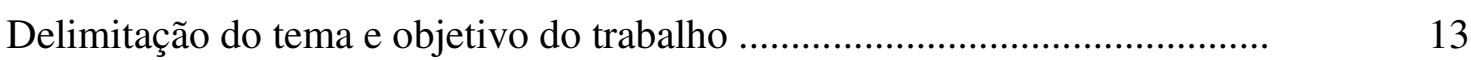

Método empregado ......................................................................................... 15

As palavras, conceitos e definições ......................................................... 16

As fontes e os meios de interpretação ..................................................... 17

Últimas consideraç̃̃es acerca do método empregado ................................. 18

1. A SUBSTITUIÇÃO TRIBUTÁRIA "PARA TRÁS” NO ICMS ……….......... 20

1.1. A substituição tributária na $\mathrm{LC} \mathrm{n}^{\circ} 87 / 96$................................................. 22

1.1.1. A substituição tributária "para trás" ............................................. 26

1.1.1.1. A "entrada" da mercadoria como "fato gerador" ............... 28

1.1.1.2. As mercadorias em relação às quais possível a aplicação do regime .................................................................... 29

1.2. A substituição "para trás" na Lei $n^{\circ} 6.374 / 89$.......................................... $\quad 30$

1.2.1. O inc. XXIV do art. $8^{\circ}$ da Lei $n^{\circ} 6.374 / 89$.................................. 32

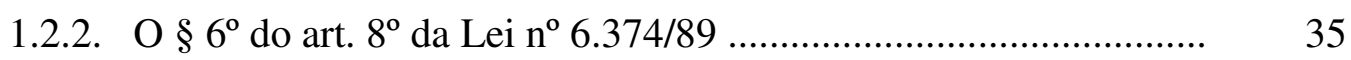

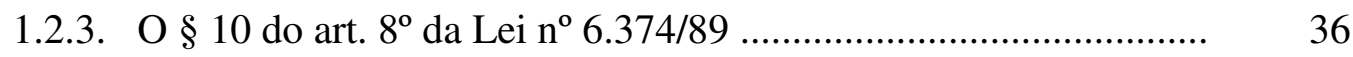

2. O LANÇAMENTO NO ICMS _....................................................................... 38

2.1. O conceito de lançamento tributário ........................................................ 38

2.2. As modalidades de constituição do crédito tributário .............................. 41

2.3. O momentos nos quais ingressam no sistema a regra individual e concreta engendrada pela Administração e a produzida pelo sujeito passivo

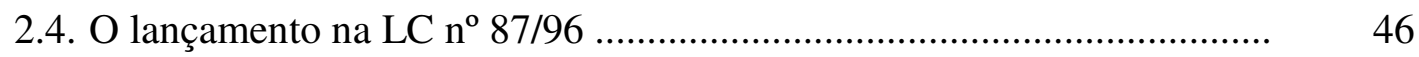

2.4.1. O regimes de apuração previstos na $\mathrm{LC} \mathrm{n}^{\circ} 87 / 96$ ……………..... $\quad 47$

2.5. O lançamento na Lei $\mathrm{n}^{\circ}$ 6.374/89 ........................................................ 49

2.5.1. A constituição do crédito tributário no regime periódico de apuração ............................................................................... 49

2.5.2. O regime de estimativa .......................................................... 53

2.5.3. Os regimes especiais de apuração …………………………….... 53

2.6. Os regimes especiais do art. 71 ............................................................. 
3. AS DISSONANTES MANIFESTAÇÕES ACERCA DO CONCEITO E DA NATUREZA JURÍDICA DO DIFERIMENTO

3.1. O diferimento como espécie de não incidência ..................................... 57

3.2. O diferimento como espécie de isenção ............................................. 58

3.3. Do diferimento como mescla de moratória e substituição ..................... $\quad 59$

3.4. O diferimento como simples dado pré-jurídico .................................... 60

3.5. O diferimento e suas relações com a substituição tributária "para trás"

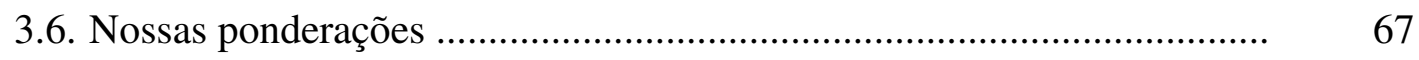

4. O DIFERIMENTO NO RICMS/00 …..................................................

4.1. As regras básicas ........................................................................ 71

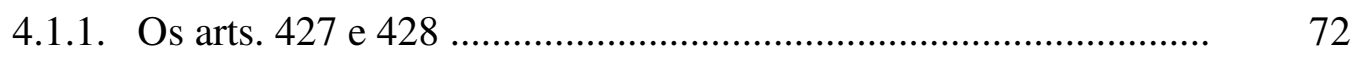

4.1.2. O arts. 429, 430 e 431 ......................................................... 75

4.2. Regras específicas: a "entrada" como termo final do diferimento do lançamento .......................................................................... 78

4.3. As mercadorias abrangidas ............................................................... $\quad 79$

4.4. Nossas conjecturas acerca do conceito e da natureza jurídica do diferimento do lançamento constante do RICMS/00

\section{A ATRIBUIÇÃO DE SUJEIÇÃO PASSIVA POR SUBSTITUIÇÃO POR} MEIO DE DIPLOMAS INFRALEGAIS

5.1. A atribuição de sujeição passiva por substituição por meio do RICMS/00

5.2. A atribuição de sujeição passiva por substituição por meio de portarias

5.2.1. O caso das operações relativas à circulação de "partes e peças para a fabricação de trator, caminhão e ônibus"

5.2.2. O caso das operações relativas à circulação de "bebidas destinadas a insumos de outras bebidas"

5.2.3. O caso das operações relativas à circulação de "insumos e produtos acabados da indústria de processamento eletrônico de dados" 
5.2.4. Outros casos do mesmo gênero .................................................. 95

5.3. O Decreto $n^{0}$ 51.608/07 ......................................................................... 96

5.4. Nossas conjecturas ........................................................................... 98

6. A PRATICABILIDADE E A COMODIDADE COMO MATRIZES INSPIRADORAS DO DIFERIMENTO DO LANÇAMENTO

6.1. Operações com feijão ............................................................................... 102

6.2. Operações com produtos têxteis .......................................................... 103

7. A INOBSERVÂNCIA DO PRINCÍPIO DA CLAREZA …............................ 105

7.1. Operações com aves .......................................................................... 107

7.2. Operações com cominho ................................................................... 108

7.3. Operações com gado bovino e suíno ...................................................... 109

7.4. Operações com insumos agropecuários ............................................... 110

7.5. Operações com leite .......................................................................... 110

7.6. A lição do Conselho Constitucional Francês ......................................... 111

7.7. Nossas conjecturas ..................................................................... 114

8. O DIFERIMENTO E A LIVRE CONCORRÊNCIA .................................. 115

8.1. A livre concorrência ............................................................................ 115

8.2. A proteção da livre concorrência ........................................................ 118

8.3. A tributação e a livre concorrência ......................................................... 120

8.4. O princípio da neutralidade concorrencial dos tributos .......................... 121

8.5. A livre concorrência como justificativa da norma tributária .................. 123

8.6. Os reflexos do diferimento constante da legislação paulista do ICMS para o lado da concorrência. Conjecturas

\section{O DIFERIMENTO E SEU CONTROVERSO CARÁTER DE BENEFÍCIO} FISCAL

9.1. Primeira inteligência: não se cuida de benefício fiscal .......................... 130

9.2. Segunda inteligência: cuida-se de benefício fiscal .............................. 133 
9.3. O efetivo emprego do diferimento com o propósito de conferir benefício fiscal ..................................................................................... 134

9.3.1. Revisita às operações com “máquina ou implemento agrícola” .. 134

9.3.2. Revisita às operações com "insumos e produtos acabados da indústria de processamento eletrônico de dados" ....................... 135

9.3.3. Operações relativas à circulação de equinos de raça ................... 136

10. CONCLUSÕES .............................................................................. 140

REFERÊNCIAS BIBLIOGRÁFICAS _...................................................... 143 


\section{INTRODUÇÃO}

No que diz respeito aos tributos estaduais incidentes sobre a circulação de bens destinados ao consumo, já é longa a história do diferimento. No Estado de São Paulo, por exemplo, remonta ao de muito extinto IVC $^{1}$, como assinalam PAUlo CELSO BergSTROM BONILHA $^{2}$ e ANTÔNIO PINTO DA SILVA ${ }^{3}$.

Nada obstante seu largo emprego pelos Estados ${ }^{4}$, seja no período em que vigorou o ICM, seja da instituição do ICMS até o presente, o repertório de estudos acerca do tema não é volumoso. Grande parte deles veio à luz quando prevalecia o ICM, voltada sua atenção, notadamente, para o exame da natureza jurídica do diferimento e de suas relações com a regra da não-cumulatividade. Instituído o ICMS, notoriamente semelhante ao ICM no tocante a operações relativas à circulação de mercadorias, as manifestações dos estudiosos sobre o diferimento mantiveram, na essência, o mesmo rumo.

Pois bem: a pesquisa a que se procedeu para a elaboração deste trabalho permitiu tirar, dentre outros que serão apresentados no seu curso, os diagnósticos que se passa a registrar em seguida.

Primeiro: examinadas doutrina, jurisprudência e manifestações da Administração acerca do conceito e da natureza jurídica do diferimento no âmbito do ICM, ou do ICMS, encontra-se notável dissonância.

Segundo: no seio da CF de 1988, o vocábulo diferimento é encontrado tão só no artigo $43, \S 2^{\circ}$, III $^{5}$. Cuida-se, todavia, de dispositivo relacionado única e exclusivamente a

Tributo instituído, ao lado de outros, pela Lei $\mathrm{n}^{\circ} 2.485$, de 16 de dezembro de 1935 - e extinto pela Lei $\mathrm{n}^{\circ}$ 9.590, de 30 de dezembro de 1966, instituidora, esta, do ICM paulista.

2 Cf. Notas sobre as Deformações da Incidência Plurifásica do ICMS. Direito Tributário Atual, São Paulo, n. 23, p. $402-409$ (p. 405), 2009.

3 Cf. Lei no 440 de 1974. In: Procuradoria Geral do Estado. Direito Tributário: Conferências, outubronovembro de 1976. São Paulo: Centro de Estudos da Procuradoria Geral do Estado, p. 179-219 (p. 190), 1977; Compatibilidade do Diferimento com o Princípio da Não-Cumulatividade do I.C.M. Boletim do Centro de Estudos da Procuradoria Geral do Estado, São Paulo, v. 2, n. 17, p. 591-606, set. 1978.

4 As referências feitas aos Estados neste trabalho entendem-se feitas também ao Distrito Federal.

5 Art. 43. Para efeitos administrativos, a União poderá articular sua ação em um mesmo complexo geoeconômico e social, visando a seu desenvolvimento e à redução das desigualdades regionais. (omissis)

$\S 2^{\circ}$ - Os incentivos regionais compreenderão, além de outros, na forma da lei: (omissis) 
tributos federais, não existindo, na Carta da República, nada que se assemelhe a tanto no que respeita ao ICMS.

Terceiro: nem o vocábulo, nem nada que lhe possa fazer as vezes de modo inquestionável, é encontrado na LC nº 87/96.

Quarto: malgrado não conste da CF de 1988 e da LC nº 87/96 a multicitada palavra, ou outra que pudesse tomar seu lugar de modo irreprochável, certo é que alguns dos Estados entenderam de inseri-la em leis ordinárias ${ }^{6}$, ou até, única e exclusivamente, no seio de regulamentos. A título de exemplo: no Estado de São Paulo, o ICMS foi instituído pela Lei $n^{\circ}$ 6.374/89. Não se encontra, no corpo dessa lei, o vocábulo diferimento, nem outro termo que a ele se pareça. A despeito disso, seu atual regulamento - RICMS/00 -, na sua redação original, voltou todo o Capítulo IV do Título II do seu Livro II, num total superior a 70 (setenta) artigos, para operações relativas à circulação de mercadorias nas quais previsto princípio da clareza do tributo.

Quinto: nenhum dos estudos coletados no curso da pesquisa tratou de examinar, mais aprofundadamente, qual seja a disciplina estabelecida quanto ao diferimento em tal ou qual Estado da Federação, lacuna que parece recomendável preencher, haja vista que, malgrado a legislação do ICMS estabelecida por cada um dos 26 (vinte e seis) Estados da Federação e pelo Distrito Federal tenha um núcleo comum, decerto que não são idênticos os seus diplomas normativos.

Sexto: nada obstante se tenha atribuído a regulamento força bastante para veicular regras concernentes a diferimento, não se encontrou na doutrina nada que se relacionasse à utilização de portaria para fazê-lo. Na jurisprudência, topou-se com um caso único, malgrado relevante, haja vista cuidar-se de decisão proferida pelo Pleno do $\mathrm{STF}^{7}$. O

III - isenções, reduções ou diferimento temporário de tributos federais devidos por pessoas físicas ou jurídicas; (omissis)

6 Examinamos a legislação de oito Estados. Dentre os que empregam o vocábulo nas leis que regem o ICMS: Estado de Pernambuco (Lei $\mathrm{n}^{\circ}$ 10.259, de 27 de janeiro de 1989), Estado de Santa Catarina (Lei 10.297, de 26 de dezembro de 1996), Estado do Rio Grande do Sul (Lei $n^{\circ} 8.820$, de 27 de janeiro de 1989), Estado do Espírito Santo (Lei nº 7.000, de 27 de dezembro de 2001), Estado do Paraná (Lei 11.580, de 14 de novembro de 1996), Estado do Maranhão (Lei no 7.799, de 19 de dezembro de 2002), Estado de Alagoas (Lei n ${ }^{\circ}$ 5.900, de 27 de dezembro de 1996), Estado de Minas Gerais (Lei nº 6.763, de 26 de dezembro de 1975, na qual consolidada toda a legislação tributária estadual). Não o empregam o Estado do Pará (Lei no 5.530, de 13 de janeiro de 1989), nem o Estado de São Paulo na Lei no 6.374/89, como já registramos.

7 A ementa do acórdão: REPRESENTAÇÃO POR INCONSTITUCIONALIDADE. DIFERIMENTO TRIBUTÁRIO. NÃO AFRONTA O ART. 20 III DA CARTA DA REPÚBLICA A NORMA QUE, NO ESTADO DA BAHIA, FAZ DIFERIR O RECOLHIMENTO DO ICM QUANDO O PRODUTOR 
assunto mostra-se importante, uma vez que o Poder Executivo Paulista lançou mão de portarias para instituir o regime de diferimento do lançamento do ICMS na seara de operações relativas à circulação de uma série de mercadorias.

Sétimo: não se encontrou, na pesquisa empreendida para elaborar esta dissertação, nenhum trabalho que tenha dedicado maior atenção para os possíveis reflexos do diferimento no âmbito da concorrência - e somente um dentre os coletados, da lavra de RAFHAEL FRATTARI ${ }^{8}$, atribui ao diferimento, no campo do ICMS, força bastante para lesar o princípio da não discriminação de que se cuida no art. 152 da CF de 1988.

Oitavo: desde sempre atribuída ao diferimento a propriedade de ser prático e cômodo - para o Fisco e para os agentes econômicos, simultaneamente - no âmbito de “operações de pequeno porte, ou realizadas por contribuintes de proporções modestas, que não mantêm organização adequada de seus negócios, ou até sem um efetivo estabelecimento" - palavras de JOSÉ EdUARdo SoARES DE MELo ${ }^{9}$-, o exame do RICMS/00 permite concluir que a comodidade e a praticidade deixaram de ser o mote de sua efetiva implantação no terreno de uma considerável gama de setores da economia paulista.

Nono: algumas das disposições que, constantes do RICMS/00, dizem com diferimento, mostram-se incompatíveis com outras disposições do mesmo diploma; outras, ainda, revelam-se de difícil interpretação para os sujeitados ao imposto - e até mesmo para o profissional do Direito -, tudo a desafiar o princípio da clareza e, via de consequência, malferir o princípio da legalidade.

AGRÍCOLA DESTINE CERTOS PRODUTOS A ESTABELECIMENTO QUE DESENVOLVA, NO PRÓPRIO ESTADO, ATIVIDADE DE INDUSTRIALIZAÇÃO OU EXPORTAÇÃO PARA O EXTERIOR. REPRESENTAÇÃO IMPROCEDENTE.

(Rp 1237, Relator: Min. FRANCISCO REZEK, Tribunal Pleno, julgado em 18/12/1985, DJ 21-02-1986 PP-01713 EMENT VOL-01408-01 PP-00001).

Disponível em <http://www.stf.jus.br/portal/principal/principal.asp>. Acesso em 12 jan 2010.

8 Cf. O Diferimento e a Regra do Artigo $8^{\circ}$, Conjugado com o Item 39, Anexo II, do Regulamento Mineiro do ICMS/96. Eficaz Boletim Tributário, Belo Horizonte, n. 39, p. 2-6 (p. 5), 1998.

9 Cf. Curso de Direito Tributário. São Paulo: Dialética, 2010, p. 276. O mesmo pensamento é expressado pelo A. em ICMS - Teoria e Prática. 11. ed. São Paulo: Dialética, 2009, p. 309. 


\section{Delimitação do tema e objetivo do trabalho}

Considerado o diferimento constante da atual legislação paulista do ICMS -, o que se pretende neste trabalho pode ser resumido do seguinte modo:

a) examinar quais sejam suas características essenciais e sua adequação frente à Lei nº 6.374/89;

b) verificar se amolda-se a um dos conceitos de que falam a doutrina, o STF, o TIT e a CT-SP;

c) analisar o manejo, na sua implementação, da competência normativa do Poder Executivo;

d) refletir acerca do abandono da comodidade e da praticidade como matrizes inspiradoras de sua adoção;

e) registrar a inobservância do princípio da clareza na elaboração de uma série dos pertinentes dispositivos;

f) conjecturar a respeito dos seus possíveis efeitos no âmbito da concorrência;

g) considerar a possibilidade de estar sendo empregado com o propósito de conferir benefícios fiscais.

Muito embora a análise de textos normativos empreendida para a elaboração deste trabalho remonte aos tempos do extinto IVC, sua atenção é voltada para o diferimento tal como constava da legislação paulista do ICMS na data de 30 de dezembro de 2009. Visto que tal legislação é alvo de repetidas alterações no curso de minguados períodos de tempo ${ }^{10}$, havia que fixar um limite, pena de correr-se o risco de tornar necessário proceder

10 Para se ter uma ideia aproximada, 67 (sessenta e sete) decretos vieram a alterar o RICMS/00 no ano de 2009, quais sejam: Dec. 53.972, de 27 de janeiro de 2009; Dec. 53.973, de 27 de janeiro de 2009; Dec. 54.006, de 12 de fevereiro de 2009; Dec. 54.007, de 12 de fevereiro de 2009; Dec. 54.008, de 12 de fevereiro de 2009; Dec. 54.009, de 12 de fevereiro de 2009; Dec. 54.060, de 26 de fevereiro de 2009; Dec. 54.080, de 05 de março de 2009; Dec. 54.092, de 11 de março de 2009; Dec. 54.105, de 12 de março de 2009; Dec. 54.134, de 17 de março de 2009; Dec. 54.135, de 17 de março de 2009; Dec. 54.136, de 17 de março de 2009; Dec. 54.137, de 17 de março de 2009; Dec. 54.155, de 20 de março de 2009; Dec. 54.169, de 26 de março de 2009; Dec. 54.170, de 26 de março de 2009; Dec. 54.172, de 26 de março de 2009; Dec. 54.177, de 30 de março de 2009; Dec. 54.239, de 14 de abril de 2009; Dec. 54.249, de 17 de abril de 2009; Dec. 54.250, de 17 de abril de 2009; Dec. 54.251, de 17 de abril de 
a mudanças no seio deste trabalho até mesmo no dia em que prevista sua finalização ${ }^{11}$. Por conseguinte, quando nos referirmos a "legislação atual", ou a algo que a tanto valha, estaremos nos reportando a 30 de dezembro de 2009.

Não cuidaremos de prestação de serviço de transporte interestadual e intermunicipal, nem de comunicação. Serão abordadas tão só operações relativas à circulação de mercadorias, em particular aquelas consideradas (i) no art. 260 e (ii) no Capítulo IV do Título II do Livro II do RICMS/00. Sublinhe-se que, no curso do tempo, numerosos dos dispositivos de início agrupados no mencionado Capítulo foram revogados por meio de decretos, não sendo recomendável, no entanto, deixá-los à margem do estudo, mesmo porque, como veremos, alguns deles foram reanimados, na falta de termo mais apropriado, por meio de portarias, ou por intermédio do Decreto $\mathrm{n}^{\circ} 51.608$, de 26 de fevereiro de 2007, que, disciplinando matéria de ICMS, não reincorporou o dispositivo revivido ao próprio RICMS/00.

Ficam excluídas da dissertação, outrossim, as operações relativas a circulação de mercadorias que, abrangidas no universo daquelas submetidas ao regime de diferimento do ICMS, dizem com (i) energia elétrica ${ }^{12}$ e (ii) "petróleo, combustíveis líqüidos ou gasosos, inclusive álcool carburante, ou lubrificantes"13. Justifica-se: as particularidades de cada um desses conjuntos de operações recomendam vivamente que sejam examinados em trabalhos autônomos.

2009; Dec. 54.252, de 17 de abril de 2009; Dec. 54.289, de 04 de maio de 2009; Dec. 54.300, de 06 de maio de 2009; Dec. 54.314, de 08 de maio de 2009; Dec. 54.315, de 08 de maio de 2009; Dec. 54.337, de 15 de maio de 2009; Dec. 54.338, de 15 de maio de 2009; Dec. 54.351, de 19 de maio de 2009; Dec. 54.352, de 19 de maio de 2009; Dec. 54.375, de 26 de maio de 2009; Dec. 54.401, de 01 de junho de 2009; Dec. 54.402, de 01 de junho de 2009; Dec. 54.403, de 01 de junho de 2009; Dec. 54.422, de 05 de junho de 2009; Dec. 54.447, de 16 de junho de 2009; Dec. 54.448, de 16 de junho de 2009; Dec. 54.491, de 26 de junho de 2009; Dec. 54.506, de 01 de julho de 2009; Dec. 54.643, de 05 de agosto de 2009; Dec. 54.650, de 06 de agosto de 2009 Dec. 54.672, de 12 de agosto de 2009; Dec. 54.679, de 14 de agosto de 2009; Dec. 54.717, de 27 de agosto de 2009; Dec. 54.735, de 02 de setembro de 2009; Dec. 54.846, de 30 de setembro de 2009; Dec. 54.869, de 02 de outubro de 2009; Dec. 54.897, de 09 de outubro de 2009; Dec. 54.905, de 13 de outubro de 2009; Dec. 54.944, de 21 de outubro de 2009; Dec. 54.946, de 21 de outubro de 2009; Dec. 54.976, de 29 de outubro de 2009; Dec. 55.000, de 10 de novembro de 2009; Dec. 55.001, de 10 de novembro de 2009; Dec. 55.029, de 12 de novembro de 2009; Dec. 55.090, de 30 de novembro de 2009; Dec. 55.092, de 30 de novembro de 2009; Dec. 55.216, de 21 de dezembro de 2009; Dec. 55.302, de 30 de dezembro de 2009; Dec. 55.303, de 30 de dezembro de 2009; Dec. 55.304, de 30 de dezembro de 2009; Dec. 55.305, de 30 de dezembro de 2009; Dec. 55.306, de 30 de dezembro de 2009; Dec. 55.307, de 30 de dezembro de 2009; Dec. 55.308, de 30 de dezembro de 2009.

11 Estamos conscientes, então, de que este trabalho refere-se em parte a problemas do passado, o que não significa, porém, que não possa servir de apoio para o estudo de problemas de hoje.

12 A matéria consta do RICMS/00, art. 425.

13 A matéria consta do RICMS/00, arts. 411, 411-A, 419, 420, 421 e 422. 


\section{Método empregado}

Calha anotar, de início, que não se desconhece as objeções de PAUL FEYERABEND acerca do método. No seu entender, as atividades científicas não exigem obediência a nenhum método fundado em princípios rígidos e imutáveis e, dada uma regra de metódo qualquer, 'tão 'fundamental' e 'necessária' que seja para a ciência, sempre haverá circunstâncias nas quais será preferível não somente ignorá-la, mas adotar a regra contrária $^{14}$.

Certo é, como registra Nicola AbBagnano ${ }^{15}$, que Paul Feyerabend fazia referência a um método científico único e universal, o que não implica negação de toda e qualquer regra ou procedimento de investigação, instrumental do qual não se pode prescindir.

Pois bem: necessária a escolha de um método, entendemos de seguir, o mais de perto possível, o que KARL POPPER, muito modestamente, apresentou como sua opinião. Segundo o A., o método científico resume-se a (i) selecionar um problema, (ii) tentar resolvê-lo, propondo uma solução, (iii) examinar criticamente a solução proposta e (iv) ter em mente que tal solução engendrará novo problema, o que, por sua vez, implicará a necessidade de se propor nova solução ${ }^{16}$. Tanto é assim para as "ciências sociais" quanto para as "naturais", afirma ${ }^{17}$.

14 Cf. Contre la Méthode - Esquisse d'une Théorie Anarchiste de la Connaissance. Tradução: Baudoin Jurdant e Adnès Schlumberger. Paris: Seuil, 1979, p. 20-21.

15 MÉTODO. In: Dicionário de Filosofia. 5 ed. São Paulo: Martins Fontes, 2007, p. 780.

16 Cf. O Mito do Contexto. Lisboa: 70, 1999, p. 194. Escreveu o A.:

"A minha opinião sobre o método da ciência é, muito simplesmente, que ela sistematiza o método précientífico de aprendizagem a partir dos erros. E fá-lo por meio de um mecanismo chamado discussão crítica.

A minha visão global do método científico pode resumir-se, dizendo que ele consiste nos seguintes quatro passos.

1. Seleccionamos um problema qualquer - talvez um com que deparemos casualmente.

2. Tentamos resolvê-lo, propondo uma teoria como solução tentativa.

3. Através da discussão crítica das nossas teorias, o nosso conhecimento aumenta pela eliminação de alguns erros e, desta forma, aprendemos a compreender os nossos problemas e as nossas teorias e a necessidade de encontrar novas soluções.

4. A discussão crítica, mesmo das nossas melhores teorias, revela sempre novos problemas.

$\mathrm{Ou}$, traduzindo estes quatro passos em quatro palavras: problemas - teorias - críticas - novos problemas. Destas quatro importantíssimas categorias, a mais característica da ciência é a eliminação de erros pela crítica. Pois o que chamamos vagamente objectividade da ciência, e racionalidade da ciência, são meros aspectos da discussão crítica das teorias científicas."

17 Cf. Em Busca de um Mundo Melhor. São Paulo: Martins, 2006, p. 95. 
Levamos em conta, também, que não há de se buscar a certeza como meta, pois o conhecimento científico é sempre hipotético, é um saber conjectural ${ }^{18}$, reconhecendo-se, portanto, que em ciência só o provisório é definitivo ${ }^{19}$.

Admitimos, por conseguinte, que o trabalho, malgrado o ingente esforço empreendido com o fim de evitar erros, decerto os contém. Isto não o desmerece de plano. $\mathrm{O}$ conhecimento somente pode progredir graças à crítica - e as conjecturas aqui apresentadas estão expostas à refutação, como não poderia deixar de $\operatorname{ser}^{20}$.

\section{As palavras, conceitos e definições}

No tocante ao vocábulo diferimento, damos como irrelevante qualquer disputa sobre sua significação, seguindo MARÇAL JUSTEN FILHO. Nas suas palavras, "não será a partir dessa significação que poderemos descobrir o conceito e a natureza jurídica do instituto", o que dependerá, isto sim, da consideração dos "elementos jurídicos relevantes em jogo" $" 21$.

É seguro que conceitos já formulados pelos estudiosos acerca dos temas que se pretende examinar serão levados em conta, mas o trabalho não se caracteriza por comprometimento com nenhuma específica orientação doutrinária. Embora reverentes ao quanto produzido pela doutrina - e agradecidos aos que se ocuparam de criá-la -, não podemos desconsiderar de plano o quanto ensinado por Michel VILLEY: devemos nos servir das doutrinas como um marceneiro consciencioso ensaia suas limas uma depois da outra, mas não é imperativo que a elas nos submetamos ${ }^{22}$.

Sobre palavras e conceitos, ainda uma vez buscamos o apoio de KARL POPPER: (i) são meros instrumentos para a formulação de enunciados, conjecturas ou teorias - e como tais não podem ser verdadeiros ou falsos, e (ii) servem apenas à linguagem humana

18 Cf. POPPER, Karl R. Em Busca de um Mundo Melhor. São Paulo: Martins, 2006, p. 15.

19 Cf. BORGES, José Souto Maior. Revisitando a Isenção Tributária - A Isenção Tributária à Luz da Hermenêutica Histórica. Revista de Direito Tributário n. 71, p. $24-29$ (p. 24), s.d.; A Isonomia Tributária na Constituição Federal de 1988. Revista de Direito Tributário, São Paulo, n. 64, p. 8-19 (p. 9), s/d.

20 Na busca do conhecimento, "toda crítica consiste em tentativas de refutação", como escreveu Karl Popper. Cf. Em Busca de um Mundo Melhor. São Paulo: Martins, 2006, p. 95.

21 Cf. Sujeição Tributária Passiva. Belém: CEJUP, 1986, p 329.

22 Cf. Réflexions sur la Philosophie et le Droit - Les Carnets. Paris: PUF, 1995, p. 25. A tradução do francês para o português é de nossa responsabilidade. 
descritiva e argumentativa. O propósito do estudioso, adverte, "não deve ser analisar significados, mas buscar verdades significativas e interessantes" 23 .

No tocante a definições, não podemos nos furtar de novamente invocar KARL POPPER $^{24}$ :

A clareza é um valor intelectual em si; mas a exatidão e a precisão não. A absoluta precisão é inalcançável; e não faz sentido querer ser mais exato do que exige nosso problema. A idéia de que precisamos definir nossos conceitos para torná-los 'precisos' e até mesmo para lhes dar um 'sentido' é um fogo-fátuo. Pois toda definição precisa utilizar conceitos definidores; e assim jamais podemos evitar trabalhar, em última instância, com conceitos não definidos.

Concluindo este tópico, firmamos que, neste trabalho, ensaiaremos de primar pela clareza tanto quanto nos for possível, nada obstante sabedores que já de início derrotados quanto às absolutas exatidão e precisão. Não se cuida de falsa modéstia, mas de reconhecer limitações.

\section{As fontes e dos meios de interpretação}

As fontes que serviram para a elaboração das conjecturas apresentadas neste trabalho, em resumo:

a) a Constituição Federal de 1988;

b) a legislação infraconstitucional, de leis complementares a portarias;

c) a doutrina nacional, predominantemente - e estrangeira, ocasionalmente;

d) a jurisprudência, aí compreendidas decisões do Poder Judiciário e do TIT;

e) respostas fornecidas pela CT-SP às consultas formuladas pelos particulares.

\footnotetext{
23 Cf. Em Busca de um Mundo Melhor. São Paulo: Martins, 2006, p. 229.
}

24 Idem, p. 75 
$\mathrm{Na}$ interpretação do feixe de normas pertinentes ao tema foram empregados os meios consagrados no Direito.

\section{Últimas considerações acerca do método empregado}

Nada embora lidos e relidos os estudos elaborados pela doutrina acerca do diferimento no tocante ao ICM e ao ICMS, parece-nos que todos - e se algum deles faltou, tratamos de apresentar desde já nossas escusas -, não se pretendeu, na elaboração deste trabalho, fazer uma dissecção exaustiva de cada qual. Estabeleceu-se como foco primário, importante frisar, a legislação a ele relativa.

Por outro lado, evitou-se resvalar para extensa casuística, registrando pormenores que desviariam a atenção dos aspectos nucleares do tema.

Além do método por intermédio do qual empreendida a investigação e no qual sustentadas - esperamos - nossas conjecturas, parece-nos interessante registrar algumas linhas acerca do critério adotado para redigir o texto.

O diferimento do lançamento constante da legislação paulista do ICMS, ao demais do seu óbvio e estreito vínculo com o tema do lançamento tributário, guarda estreita relação com o tema da sujeição passiva por substituição tributária no tocante ao que a LC n 87 nomina de "operações antecedentes". Este o universo que interessa examinar neste trabalho. Prestigiando a objetividade e a concisão, deixaremos de lado um sem número de aspectos do ICMS. É que, malgrado não careçam de importância para quem deseje conhecer amplamente a legislação concernente ao tributo, abordá-los implicaria afastar nossa atenção do núcleo do trabalho.

Quanto à linguagem, também nos esforçamos em seguir recomendação de KARL POPPER: é tarefa do estudioso reduzir o jargão científico ao mínimo e empregar linguagem simples e despretensiosa ${ }^{25}$.

Cabe sublinhar, por relevante, que o trabalho não tem a ambição de ofertar respostas definitivas, mas o modesto objetivo de veicular conjecturas.

25 Idem, p. 64. O mesmo pensamento é expressado em O Mito do Contexto. Lisboa: 70, 1999, p. 140. 
O que se espera é que, na avaliação deste trabalho, se leve em conta a argumentação - e não a erudição, mesmo porque, sempre atentos às ideias desenvolvidas por KARL POPPER, temos em mente que nossa massa de ignorância é muito maior do que a de nossos conhecimentos ${ }^{26}$.

26 Cf. Em Busca de um Mundo Melhor. São Paulo: Martins, 2006, p. 76. Escreveu o A.:"Quanto mais aprendemos acerca do mundo, quanto mais aprofundamos nosso conhecimento, mais consciente, claro e firmemente traçado será nosso conhecimento sobre o que não conhecemos, nosso conhecimento sobre nossa ignorância. A fonte principal de nossa ignorância reside em que nosso conhecimento só pode ser limitado, enquanto nossa ignorância é necessariamente ilimitada.” 


\section{A SUBSTITUIÇÃO TRIBUTÁRIA “PARA TRÁS” NO ICMS}

A CF de 1988 determinou, de início no seu art. 155, inc. I, al. "b" aos Estados e ao Distrito Federal instituir imposto sobre operações relativas à circulação de mercadorias e sobre prestações de serviços de transporte interestadual e intermunicipal e de comunicação - e estabeleceu, no seu art. 155, $\S 2^{\circ}$, inc. XII, que caberia a lei complementar $^{28}$, no tocante ao mesmo tributo, definir seus contribuintes (al. "a"), dispor sobre substituição tributária (al. "b"), disciplinar o regime de compensação do imposto (al. "c"), fixar, para efeito de sua cobrança e definição do estabelecimento responsável, o local das operações relativas à circulação de mercadorias e das prestações de serviços (al. "d"), excluir da incidência do imposto, nas exportações para o exterior, serviços e outros produtos além dos mencionados na al. "a “ do inc. X (al. "e"), prever casos de manutenção de crédito, relativamente à remessa para outro Estado e exportação para o exterior, de serviços e de mercadorias (al. "f"), regular a forma como, mediante deliberação dos Estados e do Distrito Federal, isenções, incentivos e benefícios fiscais serão concedidos e revogados (al. "g" ${ }^{29}$.

O emprego da expressão "substituição tributária" não foi feliz. Nada impede que texto constitucional encerre conceitos exógenos, isto é, "provenientes de outras searas do direito ou mesmo do campo extrajurídico", como observou CELSO RIBEIRO BASTOS ${ }^{30}$. Sucede que o conceito de "substituição tributária" sempre foi objeto de controvérsias e a técnica legislativa recomenda que "em face de um conceito doutrinário controvertido, será sempre preferível que o legislador procure resolver a situação por meios diversos" ${ }^{\text {}}$.

27 Com a Emenda Constitucional n ${ }^{\circ}$ 3, de 1993, o texto passou a ser acomodado no art. 155, inc. II.

28 Não se vai examinar, aqui, o longo debate acerca da fixação do papel da lei complementar em matéria tributária: o tema refoge ao objeto deste trabalho.

29 Por meio da Emenda Constitucional $n^{\circ} 33$, de 2001, foram acrescentadas, ao inc. XII do $\S 2^{\circ}$ do art. 155 da Constituição Federal, duas alíneas. Ambas dizem com atribuições conferidas a lei complementar. A primeira delas, alínea "h", diz com a definição dos "combustíveis e lubrificantes sobre os quais o imposto incidirá uma única vez, qualquer que seja a sua finalidade, hipótese em que não se aplicará o disposto no inc. X, al. " $b$ "; a segunda, alínea "i", diz com a fixação da base de cálculo do tributo, "de modo que o montante do imposto a integre, também na importação do exterior de bem, mercadoria ou serviço".

30 Cf. Hermenêutica e Interpretação Constitucional. São Paulo: Celso Bastos/Instituto Brasileiro de Direito Constitucional, 1997, p. 114

31 Cf. LEAL, Victor Nunes. Problemas de Direito Público. Rio de Janeiro: Forense, 1960, p. 31. 
Tanto é recomendável que se deixe de lado conceitos controvertidos na elaboração de textos constitucionais que, para cuidar de variedade do que a doutrina já de muito apelidara de "substituição tributária", o Constituinte Derivado não empregou a expressão, nem valeu-se de "substituto tributário". Decerto que nos referimos à Emenda Constitucional $\mathrm{n}^{\circ} 3$, de 17 de março de 1993, por meio da qual ${ }^{32}$ se acrescentou, ao art. 150 da CF de 1988, o seu $\S 7^{\text {o33 }}$. O Constituinte Derivado poderia, se quisesse, empregar uma dessas expressões, mas preferiu alongar-se e registrar que a lei poderia "atribuir a sujeito passivo de obrigação tributária a condição de responsável pelo pagamento de imposto ou contribuição, cujo fato gerador deva ocorrer posteriormente".

De qualquer modo, todos os elementos e conceitos encerrados num texto constitucional - aí incluídos os conceitos exógenos, e os conceitos controvertidos, certo está -, "têm de ser entendidos em conexão com os demais e analisados tendo em conta quer o seu originário sentido (em princípio, "recebido") quer o que lhe advém da sua colocação sistemática" ${ }^{\text {34 }}$. Parafraseando CELSO RIBEIRO BASTOS: tal como constante do art. $155, \S 2^{\circ}$, inc. XII, al. “b”, a expressão "substituição tributária” deve ser interpretada de acordo com a tradição existente em torno dela ${ }^{35}$.

Pois bem: prevendo o Constituinte que a lei complementar necessária para explicitar o que dissesse respeito ao ICMS não viria à luz tão cedo, ficou determinado, no $\S 8^{\circ}$ do art. 34 do ADCT, que, acaso não editada no prazo de sessenta dias, caberia aos Estados e ao Distrito Federal, mediante convênio celebrado nos termos da LC no $24 / 75^{36}$, fixar normas para regular provisoriamente a matéria.

32 Dentre outras alterações.

33 CF de 1988, art. $150, \S 7^{\circ}$ : A lei poderá atribuir a sujeito passivo de obrigação tributária a condição de responsável pelo pagamento de imposto ou contribuição, cujo fato gerador deva ocorrer posteriormente, assegurada a imediata e preferencial restituição da quantia paga, caso não se realize o fato gerador presumido. (Incluído pela Emenda Constitucional nº 3, de 1993).

34 Cf. MIRANDA, Jorge. Teoria do Estado e da Constituição. Rio de Janeiro: Forense, 2007, p. 452.

35 Segundo o A., "sendo a Lei Suprema, a Constituição não encontra acima dela outros textos normativos que a vinculem. Daí esse caráter de inicialidade, que do ângulo estritamente interpretativo impõe que seus termos e vocábulos sejam interpretados a partir dela mesma. Se se tratar de palavras de uso comum é este que deverá prevalecer. Se se tratar, contudo, de um termo técnico, o que se deve tomar em conta é toda a tradição existente em torno dele.”. Cf. Curso de Direito Constitucional. 14. ed. São Paulo: Saraiva, 1992, p. 103.

36 Cuida-se da lei complementar que, segundo está na sua ementa, "Dispõe sobre os convênios para a concessão de isenções do imposto sobre operações relativas à circulação de mercadorias, e dá outras providências.". 
Concretizada a demora, os Estados e o Distrito Federal celebraram o Convênio ICM $n^{\circ} 66 / 88^{37}$, avença cujas disposições, vertidas no seu Anexo Único, só deixaram de prevalecer em $1^{\circ}$ de novembro de 1996 , quando passou a irradiar efeitos a LC no $87 / 96^{38}$, diploma explicitador cuja necessidade o Constituinte previra já havia oito anos - e que vigora até os dias de hoje, nada obstante as sucessivas alterações de seu texto original ${ }^{39}$.

Considerada sua redação atual - e o propósito deste trabalho -, merece comentário especial o quanto disposto pela LC no $87 / 96$ acerca de substituição tributária ${ }^{40}$.

Em tempo: para os fins deste trabalho, fica adotado o quanto ensina JosÉ EDUARDO SOARES DE MELO a respeito de substituição tributária. Segundo o A., trata-se de “imputação de responsabilidade por obrigação tributária de terceiro, que não praticou o fato gerador, mas que tem vinculação indireta com o real contribuinte" ${ }^{41}$. Acrescenta: "Na substituição - num plano pré-jurídico - o legislador afasta, por completo, o verdadeiro contribuinte, que realiza o fato imponível, prevendo a lei - desde logo - o encargo da obrigação a uma outra pessoa (substituto), que fica compelida a pagar a dívida própria, eis que a norma não contempla dívida de terceiro (substituído)"42.

\subsection{A substituição tributária na $L C n^{0} 87 / 96$}

Observação necessária: ao dispor sobre substituição tributária, a LC no 87/96 dirigese ao legislador estadual. Vale dizer: a LC no 87/96 não institui o regime ele substituição tributária, mas tão somente fixa diretrizes a serem obedecidas pelo legislador estadual. Prossigamos.

A LC nº 87/96 é rica de dispositivos pertinentes a substituição tributária. Estão direta e notadamente dirigidos para o tema os seus arts. $6^{\circ}, 7^{\circ}, 8^{\circ}, 9^{\circ}$ e 10 .

37 Atribuiu-se ao Convênio ICM n” 66/88 a seguinte ementa: "Fixa normas para regular provisoriamente o ICMS e dá outras providências."

38 Sua ementa: "Dispõe sobre o imposto dos Estados e do Distrito Federal sobre operações relativas à circulação de mercadorias e sobre prestações de serviços de transporte interestadual e intermunicipal e de comunicação, e dá outras providências."

39 O texto original da $\mathrm{LC} \mathrm{n}^{\circ}$ 87/96 foi alterado, no decorrer do tempo, pelas $\mathrm{LC} \mathrm{n}^{\circ}$ 92, de 23 de dezembro de 1997, LC n $^{\circ}$ 99, de 20 de 20 de dezembro de 1999, LC n $^{\circ} 102$, de 11 de julho de 2000, LC ${ }^{\circ} 114$, de 16 de dezembro de 2001, LC n⿳⺈ 115 , de 26 de dezembro de 2002, LC n ${ }^{\circ} 120$, de 29 de dezembro de 2005, e $\mathrm{LC} \mathrm{n}^{\circ} 122$, de 12 de dezembro de 2006.

40 Não cuidaremos, aqui, de examinar os acesos debates acerca dos efeitos do emprego da substituição tributária para o lado do ICMS, por cuidar-se de tema que desborda dos limites deste trabalho.

41 Cf. ICMS: Teoria e Prática. 11 ed. São Paulo: Dialética, 2009, p. 198.

42 Idem, p. 199. 
Parece-nos conveniente registrar desde logo: tratando-se o ICMS de imposto cujo regramento é de ser estabelecido privativamente pelos Estados e pelo Distrito Federal com a ressalva dos poderes conferidos ao Senado Federal nos incisos IV e V do art. 155, $\S 2^{\circ}$, da CF de 1988 -, e sabendo-se que a LC n ${ }^{\circ} 87 / 96$ estabeleceu diretrizes acerca de substituição tributária, é necessário concluir que, no tocante ao ICMS, carece de maior importância o quanto previsto no art. 128 do CTN, dispositivo este que, no Brasil, deu amparo ao que se decidiu chamar de substituição tributária - e deu origem a um acervo de trabalhos intelectuais caracterizados por marcantes divergências ${ }^{43}$.

Não se cuida de nenhuma espécie de revogação, nem de modificação: como está no $\S 2^{\circ}$ do art. $2^{\circ}$ do Decreto-Lei $n^{\circ} 4.657$, de 4 de setembro de 1942 (Lei de Introdução ao Código Civil Brasileiro), a lei nova que estabeleça disposições gerais ou especiais a par das já existentes não revoga nem modifica a lei anterior. Sim, as regras acerca da substituição tributária constantes da LC no 87/96 devem ser consideradas, frente ao quanto enfeixado no CTN a respeito da mesma matéria, como regras especiais, a teor do que ensinou VICTOR NUNES LEAL, para quem são regras comuns ou gerais aquelas "de aplicação genérica e ampla, que regulam o maior número das hipóteses enquadradas nos tipos legais" e especiais "as que regulam determinado número de situações, de amplitude mais ou menos considerável, sujeitando-as a um tratamento diferente" 44 , bem assim PAULO DOURADO DE GUSMÃO, segundo quem, tendo em mente as relações sociais reguladas pelo direito, "as normas podem ser de direito geral, quando são aplicadas a todas as relações, e de direito especial, quando aplicadas somente a um campo restrito de relações sociais" ${ }^{45}$, deixando registrado o A. que as relações sociais regidas pela norma de direito especial exibem semelhanças com as disciplinadas pelo direito geral, mas delas se distinguem por aspectos que as fazem exigir tratamento especial.

Ainda que se levantem objeções quanto a dar a $\mathrm{LC} \mathrm{n}^{\circ}$ 87/96 como lex specialis em relação ao CTN, é seguro que a CF de 1988 determinou que, no tocante ao ICMS, cabia a

43 Por todos: RODRIGUES, Walter Piva. Substituição Tributária. São Paulo: Quartier Latin, 2004; BECKER, Alfredo Augusto. Teoria Geral do Direito Tributário. 3. ed. São Paulo: Lejus, 2002, p. 530578; BORGES, Arnaldo. O Sujeito Passivo da Obrigação Tributária. São Paulo: Revista dos Tribunais, 1981, p. 114-119; COÊLHO, Sacha Calmon Navarro. Estudo sobre a Sujeição Passiva Direta e Indireta no Direito Brasileiro - Escólios para uma Futura Modificação do Código Tributário Nacional - Em Homenagem a Geraldo Ataliba. Revista de Direito Tributário, São Paulo, n. 67, p. 268-278, s/d.; FALCÃO, Amílcar de Araújo. Introdução ao Direito Tributário. 6. ed. Rio de Janeiro: Forense, 1999, p. 88-92; GIARDINO, Cléber. Relação Jurídica Tributária e o Aspecto Pessoal que a Integra. Revista de Direito Público, São Paulo, n. 25, ano VI, p. 183-195 (p. 190-195), jul./set. 1973.

44 Cf. Problemas de Direito Público. Rio de Janeiro: Forense, 1960, p. 48.

45 Cf. Introdução à Ciência do Direito. Rio de Janeiro: Forense, 1960, p. 80-81. 
lei complementar "definir seus contribuintes" e "dispor sobre substituição tributária", donde atribuiu, ao legislador complementar, competência plena para estabelecer diretrizes acerca de ambas as matérias, sem restringi-lo a nada que não estivesse na própria Carta. É bem verdade que soaria por demais estranho - e de todo inovador - que lei constitucional estabelecesse que lei complementar destinada a dispor sobre determinado assunto devesse ter como padrão demarcatório o que outra lei complementar eventualmente dispusesse, ainda que mais genericamente, sobre o mesmo assunto.

Pois bem: no seu art. $4^{\circ}$, a LC $n^{\circ} 87 / 96$ delimita o universo de contribuintes do ICMS $^{46}$. No seu art. $6^{047}$, cabeça, confere ao legislador estadual competência bastante para "atribuir a contribuinte do imposto, ou a depositário a qualquer título, a responsabilidade pelo seu pagamento, hipótese em que assumirá a condição de substituto tributário" - e no $\S 1^{\circ}$ do mesmo artigo dispõe que tal "responsabilidade poderá ser atribuída em relação ao imposto incidente sobre uma ou mais operações ou prestações, sejam antecedentes, concomitantes ou subseqüentes".

AA. de escol diagnosticaram, no exame do citado art. $6^{\circ}$, a ocorrência de vedada delegação de competência, o que os levou a taxarem-no de inconstitucional. Segundo EDVALDO BRITO, somente à lei complementar se atribuiu dispor sobre substituição tributária, atribuição esta que não poderia ser transferida "para qualquer outra norma, sob pena de admitir-se a proibida integração da Constituição por norma que, assim, toma a

46 Art. $4^{\text {o }}$ - Contribuinte é qualquer pessoa, física ou jurídica, que realize, com habitualidade ou em volume que caracterize intuito comercial, operações de circulação de mercadoria ou prestações de serviços de transporte interestadual e intermunicipal e de comunicação, ainda que as operações e as prestações se iniciem no exterior.

Parágrafo único. É também contribuinte a pessoa física ou jurídica que, mesmo sem habitualidade ou intuito comercial: (Redação dada pela LC 114, de 16.12.2002)

I - importe mercadorias ou bens do exterior, qualquer que seja a sua finalidade; (Redação dada pela LC 114, de 16.12.2002)

II - seja destinatária de serviço prestado no exterior ou cuja prestação se tenha iniciado no exterior;

III - adquira em licitação mercadorias ou bens apreendidos ou abandonados; (Redação dada pela LC 114, de 16.12.2002)

IV - adquira lubrificantes e combustíveis líquidos e gasosos derivados de petróleo e energia elétrica oriundos de outro Estado, quando não destinados à comercialização ou à industrialização. (Redação dada pela LC 102, de 11.7.2000)

47 Art. $6^{\circ}$ - Lei estadual poderá atribuir a contribuinte do imposto ou a depositário a qualquer título a responsabilidade pelo seu pagamento, hipótese em que assumirá a condição de substituto tributário. (Redação dada pela LC 114, de 16.12.2002)

$\S 1^{\circ}$ A responsabilidade poderá ser atribuída em relação ao imposto incidente sobre uma ou mais operações ou prestações, sejam antecedentes, concomitantes ou subseqüentes, inclusive ao valor decorrente da diferença entre alíquotas interna e interestadual nas operações e prestações que destinem bens e serviços a consumidor final localizado em outro Estado, que seja contribuinte do imposto.

§ 2o A atribuição de responsabilidade dar-se-á em relação a mercadorias, bens ou serviços previstos em lei de cada Estado. (Redação dada pela LC 114, de 16.12.2002) 
Constituição de rígida em flexível, por não obedecer, a lei infraconstitucional, ao quorum específico por ela exigido para norma integrativa" ${ }^{\text {48 }}$. O mesmo pensamento foi revelado por Hugo DE BRITO MACHADO. Reportando-se ao art. 155, § 2, XII, al. "b”, o A. afirma que a LC no 87/96 não chegou a dispor sobre substituição tributária, mas, "desobediente ao preceito constitucional", não ditou "norma nenhuma reguladora dessa matéria", findando por dispor, "isto sim, sobre competência legislativa"49.

Nada embora o respeito que mereçam os AA. logo acima invocados, vem a lanço relembrar PONTES DE MIRANDA, segundo quem a lei complementar tributária não é "lei de tributação", mas "lei sobre leis de tributação" fixar as diretrizes que incumbiria ao legislador estadual observar: a CF de 1988, ao determinar que caberia à lei complementar dispor sobre substituição tributária no âmbito do ICMS, não atribuiu ao legislador complementar a tarefa de discriminar pormenorizadamente quais fossem as operações relativas a circulação de mercadoria nas quais a tributação deveria ter lugar de acordo com o regime de substituição tributária, nem enumerar com precisão quais fossem os conjuntos de agentes econômicos que, implicados em operações relativas a circulação de mercadoria, deveriam agir de acordo com o regime.

Tivesse o legislador complementar obrado diversamente, descendo a minúcias, aí sim teria desbordado da competência que lhe foi outorgada. Como escreveu HeLENO TAVEIRA TÔRRES ao examinar o tema da função das leis complementares no sistema tributário nacional, "serão inconstitucionais quaisquer leis editadas a título de normas gerais que caiam em particularismos ou que se afastem dos aspectos fundamentais ou básicos, descendo a pormenores ou detalhes, pelo risco de implicar interferências nas competências alheias" $"$.

48 Cf. ICMS: Inconstitucionalidades da Lei Complementar 87/96. Substituição Tributária. Aplicabilidade do Decreto-lei 406/68. Revista Dialética de Direito Tributário. n. 16. p. $59-75$ (p. 69), jan. 1997. O A. revela o mesmo pensamento em: Problemas Jurídicos Atuais do ICMS. In: ROCHA, Valdir de Oliveira (coord.). O ICMS, a LC 87/96 e Questões Jurídicas Atuais. São Paulo: Dialética, 1997, p. 81-117 (p. 95); A Substituição Tributária no ICMS. Revista Dialética de Direito Tributário, São Paulo, n. 2, p. 24-31 (p. 29), 1995.

49 Cf. Aspectos Fundamentais do ICMS. São Paulo: Dialética, 1997, p. 119-120. O mesmo pensamento é expressado em MACHADO, Hugo de Brito; MACHADO SEGUNDO, Hugo de Brito. ICMS. Substituição Tributária "para Frente”. Operações com Veículos Automotores. Tabelas Nacionais de Preços. Frete. Não-Inclusão. Efeitos. Revista Dialética de Direito Tributário, São Paulo, n. 84, p. 151166 (p. 158), set. 2002.

50 Cf. Comentários à Constituição de 1967. Tomo II. 2. ed. São Paulo: Revista dos Tribunais, 1970, p. 83.

51 Cf. Funções das Leis Complementares no Sistema Tributário Nacional - Hierarquia de Normas - Papel do Código Tributário Nacional no Ordenamento. Revista de Direito Tributário, São Paulo, n. 84, p. 5069 (p. 59), 2002. 
A respeito do tema, vale lembrar o julgado do STJ do qual tirada a seguinte ementa, aqui apresentada com grifo nosso:

$$
\begin{aligned}
& \text { TRIBUTÁRIO - ICMS - SUBSTITUIÇÃO TRIBUTÁRIA - MANDADO } \\
& \text { DE SEGURANÇA - LEGITIMIDADE - LEI COMPLEMENTAR } \\
& \text { N. 87/96 - DELEGAÇÃO À LEI ORDINÁRIA - POSSIBILIDADE. }
\end{aligned}
$$

1. Restringe-se a controvérsia sobre a invalidação do regime de substituição tributária, diante da inconstitucionalidade do $\S 7^{\circ}$, do art. 150 , da $\mathrm{CF} / 88$, introduzido pela EC 03/93, e dos arts. $5^{\circ}, 6^{\circ}$ e $8^{\circ}$ da Lei Complementar $n$. $87 / 96$.

2. A jurisprudência dominante desta Corte Superior é tranqüila ao afirmar que é legítima a exigência do recolhimento antecipado do ICMS, pelo chamado regime de substituição tributária. (EREsp 151.501/PR, Rel. Min. Hélio Mosimann, DJ 5.10.1998).

3. Os arts. $5^{\circ}, 6^{\circ}$ e $8^{\circ}$, da Lei Complementar n. 87/96, delegam à lei ordinária competência para atribuição específica a terceiro de antecipar o recolhimento da obrigação tributária concernente ao ICMS. Esta delegação encontra respaldo na própria Constituição, pois quando esta, nos seus arts. 146, III, a, e 155, II, $\S 2^{\circ}, X I I, b, d a C F / 88$, refere-se à definição da substituição tributária por lei complementar, está se incumbindo do dever de tratar das normas gerais do instituto e não de descer em minúcias regulando exaustivamente a matéria.

4. A lei ordinária é que tem a tarefa de descrever a hipótese de incidência do tributo, e, sendo o caso, regular o regime de substituição tributária atribuindo a terceiro a responsabilidade pelo recolhimento do tributo.

Recurso ordinário improvido.

(RMS 11.691/ES, Rel. Ministro Humberto Martins, Segunda Turma, julgado em 16/08/2007, DJ 28/08/2007 p. 219)

\subsubsection{A substituição tributária "para trás"}

Como anunciamos mais acima, o diferimento que nos interessa examinar tem relação com a substituição tributária no que voltada às "operações antecedentes" de que se cogita no $\S 1^{\circ}$ do art. $6^{\circ}$ da $\operatorname{LC} n^{\circ} 87 / 96$, o que tem sido apontado como substituição "para trás".

No tocante ao ICMS, falar de substituição tributária "para trás" significa dizer, nas palavras de RoQUE ANTONIO CARRAZZA, que "o tributo será recolhido, pelo substituto, na 
próxima operação jurídica (em nome do substituído)", de modo que "a carga econômica do tributo não será suportada pelo realizador da operação jurídica (o substituído), mas por quem levar a cabo a seguinte (o substituto)" ${ }^{, 52}$.

O entendimento não difere, na essência, daquele professado por PAULO ANTONIO FERNANDES CAMPILONGO. Segundo o A., na substituição tributária o agente dado como "substituído" promove uma operação relativa à circulação de mercadoria, mas "o imposto devido na operação fica postergado para um momento seguinte, elegendo-se, nesse caso, como responsável tributário, não mais aquele que praticou o fato jurídico tributário (substituído), mas, sim, terceira pessoa vinculada ao fato (substituto)"53.

Para RICARDo LOBO TORRES, a substituição "para trás” se dá, no âmbito do ICMS, "quando o substituto, que é um contribuinte de direito (comerciante ou industrial), adquire mercadoria de outro contribuinte, em geral produtor de pequeno porte ou comerciante individual, responsabilizando-se pelo pagamento do tributo devido pelo substituído e pelo cumprimento das obrigações tributárias" ${ }^{54}$.

Segundo José EduARdo SoARes De MElo, a substituição "para trás” tem lugar quando "o legislador atribui a determinado contribuinte a responsabilidade pelo pagamento do ICMS em relação às operações anteriores"

Ao tempo do ICM, ONALDO FRANCO JANNOTTI manifestou seu pensar no sentido de que "sempre que o destinatário da mercadoria for obrigado ao pagamento do tributo, em substituição ao remetente - que seria o contribuinte - teríamos a substituição 'para trás' (o substituído teria ficado 'para trás')",56.

Examinados o texto legal e o conteúdo das manifestações às quais nos referimos cuja essência não se afigura discrepante - é-nos permitido entender que as operações

52 Cf. ICMS. 14. ed. São Paulo: Malheiros, 2009, p. 328; Lei Complementar $n^{o}$ 87/96 - Palestras proferidas em 1996 no Tribunal de Impostos e Taxas - TIT. São Paulo: IOB, s/d, pp. 73-114 (p. 93).

53 Cf. O ICMS e a Antecipação Parcial do Imposto na Operação Interestadual de Circulação de Mercadorias. In: (Coord.) ICMS Aspectos Jurídicos Relevantes. São Paulo: Quartier Latin, 2008, p. 51-76 (p. 55).

54 Cf. Substituição Tributária e Cobrança Antecipada do ICMS. In: ROCHA, Valdir de Oliveira (Coord.). ICMS - Problemas Jurídicos. São Paulo: Dialética, 1996, p. 185-202 (p. 188); Tratado de Direito Constitucional Financeiro e Tributário. Os Tributos na Constituição. v. IV. Rio de Janeiro: Renovar, 2007. p. 282.

55 Cf. Curso de Direito Tributário. 9. ed. São Paulo: Dialética, 2010, p. 280.

56 Cf. Legitimação da Chamada Substituição Tributária "Para Frente". Revista de Direito Tributário, n. 5, p. 159-178 (p. 160), jul./set., 1978. 
relativas à circulação de mercadorias nas quais é de ser respeitada a substituição tributária "para trás" não se constituem em eventos que possam dar origem a nenhuma obrigação tributária de cunho patrimonial em desfavor dos agentes econômicos remetentes das mercadorias, mas, sim, dos agentes econômicos que funcionarem como seus destinatários ${ }^{57}$.

\subsubsection{A "entrada" da mercadoria como "fato gerador"}

No tocante a operações relativas a circulação de mercadoria, o critério temporal da hipótese de incidência do ICMS é, por excelência, o instante no qual o remetente dá saída à mercadoria. É o quanto previsto no art. 12, inc. I, da $\mathrm{LC} \mathrm{n}{ }^{\circ} 87 / 96^{58}$.

Dispõe a $\operatorname{LC} \mathrm{n}^{\circ}$ 87/96, no seu art. $7^{\circ}$, todavia, que no tocante a substituição tributária o legislador estadual pode dar, como "fato gerador" do imposto, "a entrada de mercadoria ou bem no estabelecimento do adquirente ou em outro por ele indicado"59.

Certo está que o legislador complementar empregou termos de muito criticados. Não nos deteremos em examinar a controvérsia despertada quanto ao manejo da expressão "fato gerador", isto para não nos desviarmos do quanto nos cabe examinar neste trabalho, mas quanto a "entrada", parece-nos relevante observar: o que se há de entender é que, para os efeitos da substituição tributária, a "entrada" nada mais é do que o "fato de exteriorização" da operação relativa à circulação de mercadoria, o "aspecto temporal da hipótese de incidência do tributo".

57 Justamente aí um dos motivos que levaram Alcides Jorge Costa a tecer as críticas que vale reproduzir: “(...) falar em substituição para trás neste tipo de imposto é um "non sense". Primeiro, porque a substituição exige que o substituto tenha algum tipo de vínculo com a obrigação na qual ele substitui o contribuinte, para usar da terminologia do CTN. A existência da obrigação - de qualquer obrigação principal - implica pagamento de tributo. Na chamada "substituição para trás", como falar em substituição se nenhuma obrigação existiu e tanto não existiu que ninguém jamais foi nem poderia ser obrigado a pagar nada? Segundo, porque, na substituição, a obrigação já nasce tendo o substituto como sujeito passivo. Como seria isto possível se, quando nasceram as pretensas obrigações sequer se sabia quem iria ser o substituto?"

Cf. ICMS e Substituição Tributária. Revista Dialética de Direito Tributário, São Paulo, n. 2, p. 70-95 (p. 83-84), 1995.

58 Art. 12 - Considera-se ocorrido o fato gerador do imposto no momento:

I - da saída de mercadoria de estabelecimento de contribuinte, ainda que para outro estabelecimento do mesmo titular;

59 O dispositivo não diz tão só com substituição tributária "para trás", mas também com substituição tributária relacionada às "operações subsequentes", a chamada "substituição para a frente", da qual não nos ocuparemos, dado que não se relaciona com o objeto deste trabalho. 
Sobre a matéria, vale lembrar ALCIDES JORGE COSTA: o "fato de exteriorização" corresponde ao "aspecto temporal do fato gerador" 60 , sendo certo que, no tocante à tributação, as operações relativas à circulação de mercadoria podem exteriorizar-se tanto pela saída como pela entrada da mercadoria no estabelecimento do sujeito passivo, na dependência do que for estabelecido pelo legislador ${ }^{61}$.

Também vale trazer à memória lição de GERALDO ATALIBA, proferida ao tempo do ICM: a entrada de mercadoria "não é hipótese de incidência do ICM", mas "simples aspecto temporal da hipótese de incidência do tributo" $" 62$.

\subsubsection{As mercadorias em relação às quais possível a aplicação do regime}

É do $\S 2^{\circ}$ do art. $6^{\circ}$ da $L C n^{\circ} 87 / 96$ que, no tocante a operações relativas à circulação de mercadorias, cabe à lei estadual estabelecer qual seja o rol de mercadorias em relação às quais aplicável o regime da substituição tributária ${ }^{63}$.

Necessário, portanto, que o legislador estadual discrimine quais sejam tais mercadorias, seja nominando-as expressamente, seja apontando sua classificação fiscal. Segundo MARCO AURÉlio GRECO, cuida-se de campo reservado a lei, vedada a especificação das mercadorias a atos infralegais, registrando o A. não lhe parecer "que previsões genéricas (de classes de produtos) atendam à exigência da lei complementar (por exemplo, produtos supérfluos ou veículos, sem maiores especificações)"64.

A respeito do tema, vale lembrar, também, o entendimento de WALTER PIVA RODRIGUES: a discriminação das mercadorias deve ser objeto de lei ordinária, cabendo observar "os conceitos que nortearam a taxatividade da lista de serviços pelo ISS, o que impede a edição de ato administrativo que amplie o rol de mercadorias em relação às quais o instituto pode ser criado",65.

60 Cf. ICM na Constituição e na Lei Complementar. São Paulo: Resenha Tributária, 1978, p. 103.

61 Idem, p. 106.

62 Cf. Estudos e Pareceres de Direito Tributário. v. 1. São Paulo: Revista dos Tribunais, 1978, p. 134.

63 O dispositivo não diz tão só com substituição tributária "para trás", mas também com substituição tributária relacionada às "operações subsequentes", a chamada "substituição para a frente", da qual não nos ocuparemos, como já assinalamos.

64 Cf. Substituição Tributária (Antecipação do Fato Gerador). 2. ed. São Paulo: Malheiros, 2001, p. 102103.

65 Cf. Substituição Tributária. São Paulo: Quartier Latin, 2004, p. 142-143. 


\subsection{A substituição "para trás" na Lei no 6.374/89}

Fundado na CF de 1988 e no Convênio ICM 66/88, o Estado de São Paulo trouxe à luz a Lei $\mathrm{n}^{\circ} 6.374 / 89^{66}$. O diploma vigora até os dias de hoje, malgrado objeto de sucessivas alterações. Importa destacar que, advinda a $\operatorname{LC~n}^{\circ} 87 / 96$, foi acrescentado à Lei $\mathrm{n}^{\circ} 6.374 / 89$ o seu art. $114-\mathrm{A}^{67}$, no qual ficou estabelecido que permaneceriam em vigor "as disposições da legislação" que, concernentes ao ICMS, não fossem incompatíveis com a mesma LC n 87/96, "especialmente em relação à substituição tributária, fatos geradores, base de cálculo e sujeito passivo".

Entendeu o legislador paulista de agrupar, no Título II da Lei, a matéria "Da Sujeição Passiva". Dedicou o Capítulo I deste Título, composto tão só de seu art. $7^{\circ}$, ao "Contribuinte"; o Capítulo II, voltou-o ao "Substituto", aí também empregando um só artigo, o $8^{\circ}$.

Na sua redação atual, o art. $7^{068}$, cabeça, da Lei $n^{\circ}$ 6.374/89 define contribuinte como "qualquer pessoa, natural ou jurídica, que de modo habitual ou em volume que caracterize intuito comercial, realize operações relativas à circulação de mercadorias ou preste serviços de transporte interestadual ou intermunicipal ou de comunicação". No parágrafo único do mesmo art. $7^{\circ}$ são apontadas as pessoas naturais, ou jurídicas, que, por equiparação, integram o universo de contribuintes do imposto.

66 A ementa da Lei no 6374/89: "Dispõe sobre a instituição do Imposto sobre Operações Relativas à Circulação de Mercadorias e sobre Prestação de Serviços de Transporte Interestadual e Intermunicipal e de Comunicação - ICMS".

67 Artigo 114-A - Permanecem em vigor as disposições da legislação que concernem ao Imposto sobre Operações Relativas à Circulação de Mercadorias e sobre Prestações de Serviços de Transporte Interestadual e Intermunicipal e de Comunicação - ICMS, que não sejam incompatíveis com as da Lei Complementar $n^{\circ}$ 87, de 13 de setembro de 1996, especialmente em relação à substituição tributária, fatos geradores, base de cálculo e sujeito passivo. (Artigo acrescentado pela Lei 9.399/96, de 21-111996; DOE 22-11-1996).

68 Artigo $7^{\circ}$ - Contribuinte do imposto é qualquer pessoa, natural ou jurídica, que de modo habitual ou em volume que caracterize intuito comercial, realize operações relativas à circulação de mercadorias ou preste serviços de transporte interestadual ou intermunicipal ou de comunicação. (Redação dada ao artigo pela Lei 9.399/96, de 21-11-1996; DOE 22-11-1996)

Parágrafo único - É também contribuinte a pessoa natural ou jurídica que, mesmo sem habitualidade ou intuito comercial: (Redação dada ao "caput" do parágrafo único pela Lei 11.001/01, de 21-12-2001; DOE 22-12-2001; Efeitos a partir de 22-12-2001)

1 - importe mercadoria ou bem do exterior, qualquer que seja a sua finalidade; (Redação dada ao item pela Lei 11.001/01, de 21-12-2001; DOE 22-12-2001; Efeitos a partir de 22-12-2001)

2 - seja destinatária de serviço prestado no exterior ou cuja prestação se tenha iniciado no exterior;

3 - adquira em licitação mercadoria ou bem importados do exterior e apreendidos ou abandonados;

4 - adquira energia elétrica ou petróleo, inclusive lubrificantes e combustíveis líquidos ou gasosos dele derivados oriundos de outro Estado, quando não destinados à comercialização ou à industrialização.

5 - administre ou seja sócia de fato de sociedade empresarial constituída por interpostas pessoas. (Item acrescentado pela Lei 13.918, de 22-12-2009; DOE 23-12-2009) 
Na cabeça do seu art. $8^{\circ}$, a Lei n ${ }^{\circ}$ 6.374/89 dispõe que "são sujeitos passivos por substituição, no que se refere ao imposto devido pelas operações ou prestações com mercadorias e serviços", as pessoas que aponta nos subsequentes incisos. Voltada nossa atenção para a matéria referente a substituição "para trás" no bojo de operações relativas à circulação de mercadorias, vale transcrever, neste passo, os seus incs. I, XVI, XVII, XVIII e XIX:

I - o destinatário da mercadoria - comerciante, industrial, cooperativa ou qualquer outro contribuinte, exceto produtor ou extrator de minério - quando devidamente indicado na documentação correspondente, relativamente ao imposto devido na saída promovida por produtor ou extrator de minério;

XVI - quanto a papel usado e apara de papel, sucata de metal, caco de vidro, retalho, fragmento e resíduo de plástico, de borracha ou de tecido: o contribuinte que realize as operações a seguir indicadas, relativamente ao imposto devido nas anteriores saídas promovidas por quaisquer estabelecimentos:

a) saída de mercadorias fabricadas com esses insumos;

b) saída dessas mercadorias com destino a outro Estado, ao Distrito Federal ou ao Exterior;

XVII - quanto a produto agropecuário e seus insumos ou mineral: o contribuinte que realize qualquer das operações a seguir indicadas relativamente ao imposto devido nas anteriores saídas:

a) saída com destino a outro Estado, ao Distrito Federal ou ao exterior;

b) saída com destino a estabelecimento industrial;

c) saída com destino a estabelecimento comercial;

d) saída com destino a consumidor ou a usuário final;

e) saída de estabelecimento que o tenha recebido de outro do mesmo titular, indicado como substituto nas alíneas precedentes;

f) industrialização;

XVIII - quanto a mercadoria remetida para industrialização: o contribuinte autor da encomenda, relativamente ao imposto devido nas sucessivas saídas da mercadoria remetida para industrialização, até o respectivo retorno ao seu estabelecimento; 
XIX - quanto a mercadoria remetida por produtor ou extrator de minérios a cooperativa de que faça parte: a cooperativa, relativamente ao imposto devido nessa saída;

Lidos esses dispositivos, que não calha esmiuçar, temos como necessário lembrar que ficou estabelecida na LC no 87/96 a seguinte diretriz: é do legislador ordinário a competência para enumerar quais sejam as mercadorias que, objeto de operações relativas a circulação, podem dar ensejo a que tais operações tenham a tributação subordinada ao regime de substituição tributária.

Ora bem, examinados os incisos que transcrevemos, fácil notar que a Lei $\mathrm{n}^{\circ} 6.374 / 89$ assenta que tais mercadorias são:

a) todas cuja "saída" for "promovida por produtor ou extrator de minério", desde que não funcione como destinatário da mercadoria um outro produtor, ou extrator de minério (incs. I e XIX);

b) "papel usado e apara de papel, sucata de metal, caco de vidro, retalho, fragmento e resíduo de plástico, de borracha ou de tecido" (inc. XVI)

c) "produto agropecuário e seus insumos ou mineral" (inc. XVII);

d) toda aquela remetida para industrialização por conta de terceiro (inc. VIII).

Só - e mais nada.

\subsubsection{O inc. XXIV do art. $8^{\circ}$ da Lei $n^{0} 6.374 / 89$}

O quanto está no inc. XXIV do art. $8^{\circ}$ da Lei $n^{\circ} 6.374 / 89$ é fonte de perplexidade. Segundo escrito, é sujeito passivo por substituição "o industrial, o comerciante ou o prestador de serviço, relativamente ao imposto devido pelas anteriores saídas de mercadorias ou prestações de serviço, promovidas por quaisquer outros contribuintes".

Ora, a primeira leitura do texto leva a crer que todos os industriais, comerciantes e prestadores de serviço são sujeitos passivos por substituição no tocante ao imposto devido em consequência da efetivação de "operações antecedentes". Tal interpretação implicaria 
dizer que todas as pessoas indicadas no art. $7^{\circ}$ da Lei $\mathrm{n}^{\circ}$ 6.374/89 como "contribuintes" são sujeitos passivos por substituição, pouco importando qual seja a posição ocupada por cada uma delas no processo de circulação de mercadoria. Ninguém mais seria devedor do imposto tão só em razão da operação por ele mesmo promovida, mas também pelo imposto respeitante às operações precedentes. Algo semelhante foi diagnosticado por HUGO DE BRITO MACHAdO na legislação do ICMS cearense, indagando o A.: "se todos são substitutos, e devem recolher o imposto da operação, ou operações anteriores, quem será o substituído?"69.

De outra banda, acaso o disposto no inc. XXIV do art. $8^{\circ}$ da Lei $n^{\circ} 6.374 / 89$ fosse prestigiado, ninguém mais seria colhido pela sujeição passiva "para a frente", matéria extensamente abordada na Lei $\mathrm{n}^{\circ}$ 6.374/89, em especial no mesmo art. $8^{\circ}$. Parece óbvio que, se a sujeição passiva por substituição colhe "o industrial, o comerciante ou o prestador de serviço, relativamente ao imposto devido pelas anteriores saídas de mercadorias ou prestações de serviço, promovidas por quaisquer outros contribuintes", tal como está no dispositivo sob comento, a nenhum deles poderia ser atribuída sujeição passiva por substituição no tocante ao imposto devido pelas operações subsequentes. O quanto se vem de afirmar merece um exemplo: imaginemos que montadora de automóvel vende um deles a uma concessionária, funcionando ela mesma, montadora, como sujeito passivo por substituição no tocante ao imposto devido por todas as subsequentes operações, aí incluída aquela por meio da qual a concessionária vende o bem a um consumidor final. Tal hipótese de sujeição passiva está prevista no art. $8^{\circ}$, inc. XII, al. “a”, primeira figura, da Lei $n^{\circ}$ 6.374/89. Ora bem: se a montadora levou ao Erário o montante de tributo devido em decorrência de todas as operações, não se poder atribuir à concessionária o encargo de pagar o imposto respeitante às "operações antecedentes".

A regra do inc. XXIV do art. $8^{\circ}$ da Lei n ${ }^{\circ} 6.374 / 89$ é imprestável - e certamente não deveria constar do diploma. Pensamos que sua presença, no texto atual da Lei ${ }^{\circ}$ 6.374/89, resulta de um descuido do legislador. Expliquemos.

$\mathrm{Na}$ sua original redação, $\mathrm{o}$ art. $7^{\circ}$ da Lei $\mathrm{n}^{\circ}$ 6.374/89 elencava, dentre os “contribuintes", um número significativamente maior do que o constante de sua redação

69 Cf. Aspectos Fundamentais do ICMS. São Paulo: Dialética, 1997, p. 121-122; A Substituição Tributária no ICMS e a Lei Estadual. Repertório IOB de Jurisprudência, n. 14, p. 340-342 (p. 341), 1997; A Substituição Tributária no ICMS. Revista Dialética de Direito Tributário, São Paulo, n. 26, p. 27-37 (p. 32), 1997. 
atual $^{70}$. Estavam incluídos grande número de agentes econômicos que, na realidade, não se davam à prática habitual de operações relativas à circulação de mercadorias, nem à prestação de serviços tributados pelo ICMS. Malgrado isso, era do interesse do Estado conhecer os negócios que porventura realizassem com efetivos e reais contribuintes do ICMS - e que pudessem, ao menos em tese, ser objeto de tributação. Com o propósito de garantir o recebimento do tributo ${ }^{71}$, o Estado entendeu de imputar às pessoas que desses "falsos contribuintes", na falta de melhor expressão, adquirissem bens, ou tomassem serviços, o encargo de pagar o tributo, no papel de "substitutos", daí a fonte de origem do inc. XXIV do art. $8^{\circ}$ da Lei $n^{\circ} 6.374 / 89$. Sucede que o mencionado art. $7^{\circ}$ foi alterado significativamente, mas se esqueceu o legislador de revogar o multicitado inc. XXIV do art. $8^{\circ}$.

70 A redação original do art. $7^{\circ}$ da Lei $n^{\circ} 6.374 / 89$ :

Artigo $7^{\circ}$ - Contribuinte do imposto é qualquer pessoa, natural ou jurídica que, de modo habitual, realize operações relativas à circulação de mercadorias ou preste serviços de transporte interestadual ou intermunicipal ou de comunicação.

$\S 1^{\circ}$ - Incluem-se entre os contribuintes do imposto:

1 - o industrial, o comerciante, o produtor, o extrator e o gerador;

2 - o prestador de serviços de transporte interestadual e intermunicipal e de comunicação;

3 - a cooperativa;

4 - a instituição financeira e a seguradora;

5 - a sociedade civil de fim econômico;

6 - a sociedade civil de fim não econômico que explore estabelecimento de extração de substância mineral ou fóssil, de produção agropecuária, industrial ou que comercialize mercadoria que para esse fim adquira ou produza;

7 - os órgãos da Administração Pública, as entidades da Administração indireta e as fundações instituídas e mantidas pelo Poder Público;

8 - a concessionária ou permissionária de serviço público de transporte interestadual e intermunicipal, de comunicação e de energia elétrica;

9 - o prestador de serviços não compreendidos na competência tributária dos municípios que envolvam fornecimento de mercadoria;

10 - o prestador de serviços compreendidos na competência tributária dos municípios que envolvam fornecimento de mercadoria, com incidência do imposto estadual ressalvada em lei complementar;

11 - o fornecedor de alimentação, bebida, outras mercadorias e dos serviços que lhes sejam inerentes, em qualquer estabelecimento;

12 - qualquer pessoa indicada nos incisos anteriores que, na condição de consumidor final, adquira bem ou serviço em operações ou prestações interestaduais;

13 - qualquer pessoa, natural ou jurídica, de direito público ou privado, que promova importação de mercadoria, de bem ou de serviço do exterior ou que adquira em licitação mercadoria ou bem importados do exterior e apreendidos;

14 - os partidos políticos e suas fundações, templos de qualquer culto, entidades sindicais de trabalhadores, instituições de educação e de assistência social, sem fins lucrativos, que realizem operações ou prestações não relacionadas com suas finalidades essenciais.

$\S 2^{\circ}-\mathrm{O}$ disposto no item 7 do $\S 1^{\circ}$ aplica-se às pessoas ali indicadas que pratiquem operações ou prestações de serviços relacionados com a exploração de atividades econômicas regidas pelas normas a que se sujeitem os empreendimentos privados ou em que haja contraprestação ou pagamento de preços ou tarifas.

$\S 3^{\circ}$ - O requisito da habitualidade não é exigido para caracterizar a sujeição passiva na entrada de mercadoria importada do exterior.

71 A discutível legitimidade da pretensão de receber tributo em decorrência dessas operações não é assunto que interessa abordar no presente trabalho. 
É uma conjectura de nossa responsabilidade. Nada mais do que isso. De toda forma, entendemos que o disposto no inc. XXIV do art. $8^{\circ}$ da Lei $n^{\circ} 6.374 / 89$ caracteriza-se por incompatível com o disposto no art. $7^{\circ}$ e com os dispositivos que no mesmo art. $8^{\circ}$ dizem com substituição "para a frente". Força dessa incompatibilidade, não serve para ampliar o rol dos agentes econômicos aos quais atribuída sujeição passiva no tocante ao tributo devido em consequência de "operações antecedentes", limitando-se este rol às pessoas implicadas nos incs. I, XVI, XVII, XVIII e XIX do art. $8^{\circ}$ da Lei ${ }^{\circ} 6.374 / 89$ - e mais nenhuma.

\subsection{2. $O § 6^{\circ}$ do $\operatorname{art.} 8^{\circ}$ da Lei $n^{0} 6.374 / 89$}

$\mathrm{O} \S 6^{\circ}$ do art. $8^{\circ}$ da Lei $n^{\circ} 6.374 / 89^{72}$ reporta-se ao quanto versado no inc. XIX da cabeça do mesmo artigo. Da interpretação dos dispositivos, no seu conjunto, conclui-se que, na remessa de mercadoria levada a efeito por produtor ou extrator de minérios a cooperativa da qual seja integrante, seguida da remessa da mesma mercadoria promovida pela cooperativa em direção a (i) outro estabelecimento dela mesma, ou (ii) a estabelecimento de cooperativa central ou de federação de cooperativas de que a primeira faça parte, ou (iii) da remessa da mercadoria promovida pela cooperativa central em direção à respectiva federação de cooperativas, caberá a sujeição passiva tocante às "operações antecedentes" a quem, de todas as enumeradas, funcionar como a última destinatária da mercadoria.

Desse modo, ficou estabelecido que, em relação às mercadorias de que se cuida, possível a ocorrência de múltiplas e sucessivas operações antes de fixar-se a quem cabe o papel de sujeito passivo do imposto, pouco importando o intervalo de tempo durante o qual venham a se desenrolar.

72 Lei $n^{\circ} 6.374 / 89$, art. $8^{\circ}, \S 6^{\circ}$ - A sujeição passiva prevista no inciso XIX fica atribuída ao estabelecimento destinatário nos casos em que a cooperativa mencionada remeta a mercadoria a outro estabelecimento dela mesma ou a estabelecimento de cooperativa central ou de federação de cooperativas de que faça parte, bem como de cooperativa central para a respectiva federação de cooperativas. 


\subsection{3. $O § 10$ do art. $8^{\circ}$ da Lei $n^{0} 6.374 / 89$}

Muito embora conste do $\S 10^{73}$ do art. $8^{\circ}$ da Lei $n^{\circ}$ 6.374/89 a expressão "operações anteriores", melhor teria sido que empregasse "operações antecedentes". O deslize não assume grande importância, todavia.

Pois bem: no item "1" desse parágrafo, dispõe-se que a sujeição passiva tocante ao tributo devido em consequência das operações antecedentes, prevalece ainda que o agente econômico ao qual atribuído o papel de substituto leve a cabo "saída da mercadoria com destino a consumidor ou a usuário final ou, ainda, a pessoa de direito público ou privado não contribuinte", ou "saída da mercadoria ou prestação de serviço amparadas por nãoincidência ou isenção", ou "saída ou qualquer evento que impossibilite a ocorrência das operações ou prestações indicadas neste artigo".

Ora, cotejadas essas disposições àquelas dos incs I, XVI, XVII, XVIII e XIX da cabeça do mesmo art. $8^{\circ}, \operatorname{logo}$ vê-se que, recebida a mercadoria pelo agente econômico ao qual atribuído o papel de "substituto", a ele caberá o pagamento do imposto devido em consequência das operações antecedentes, não importa o que ocorra em seguida com a mercadoria. Venha a promover operação tributada, venha a promover operação "amparada por não-incidência ou isenção", venha a ter lugar qualquer evento que o impeça de manter a mercadoria em circulação, o "substituto" arcará com o imposto. Nenhum outro que esses destinos pode ter a mercadoria ao depois de ingressar na órbita jurídica do "substituto". Logo, do pagamento do imposto respeitante às "operações antecedentes" ele não escapará. Há uma exceção, porém: o pagamento do imposto "poderá ser dispensado" quando o "substituto" promover operação "amparada por não-incidência ou isenção" e estiver autorizada a manutenção do crédito equivalente ao montante do tributo que, não fosse a regra de substituição, teria sido pago por quem lhe remeteu mercadoria. É a exceção prevista no $\S 12$ do art. $8^{\circ}$ da Lei $n^{\circ} 6.374 / 89^{74}$.

73 Lei $\mathrm{n}^{\circ} 6.374 / 89$, art. $8^{\circ}, \S 10$ - A sujeição passiva por substituição em relação às operações anteriores previstas neste artigo:

1 - prevalece, também, sendo o caso, nas seguintes hipóteses:

a) saída da mercadoria com destino a consumidor ou a usuário final ou, ainda, a pessoa de direito público ou privado não contribuinte;

b) saída da mercadoria ou prestação de serviço amparadas por não-incidência ou isenção;

c) saída ou qualquer evento que impossibilite a ocorrência das operações ou prestações indicadas neste artigo;

2 - em relação a cada situação, mercadoria ou serviço, depende de normas complementares à sua execução, fixadas em regulamento.

74 Lei $\mathrm{n}^{\circ} 6.374 / 90$, art. $8^{\circ}, \S 12$ - O pagamento decorrente do disposto na alínea "b" do item 1 do parágrafo anterior poderá ser dispensado nos casos em que a legislação admita a manutenção do crédito. 
Vejamos, por fim, o quanto está no item "2" do $§ 10$ do art. $8^{\circ}$ da Lei nº.374/89. Segundo o dispositivo, a "execução" das regras da substituição tributária tocante às operações antecedentes, consideradas "cada situação, mercadoria ou serviço", deverá ser objeto de normas complementares fixadas em regulamento. O comentário de interesse que nos ocorre: decerto que tais normas complementares devem referir-se ao elenco de mercadorias apontado pela própria Lei $\mathrm{n}^{\circ} 6.374 / 89$ - as assinaladas nos I, XVI, XVII, XVIII e XIX do seu art. $8^{\circ}$-, não cabendo ao Poder Executivo, por meio do aventado regulamento, nem aumentar, nem diminuir o rol. Os termos "execução" e "normas complementares" jamais permitiriam que outra interpretação fosse adotada, que alguém pensasse estar na competência do Poder Executivo tornar maior o conjunto das mercadorias em relação às quais possível aplicar a substituição tributária "para trás" - e via de consequência, atribuir sujeição passiva por substituição a alguém que não aqueles apontados como "substitutos" na própria Lei n 6.374/89.

Nota nossa: muito embora esteja escrito "na alínea 'b' do item 1 do parágrafo anterior", o correto seria “na alínea 'b' do item 1 do $\S 10$ ”, já que (i) do $\S 11$ não consta nenhuma alínea e (ii) o pagamento e o crédito dos quais se trata no $\S 12$ só podem dizer respeito ás hipóteses de "não-incidência ou isenção" das quais se cuida na alínea "b" do item " 1 " do $\S 10$ do art. $8^{\circ}$. Para que não sobre dúvida quanto a este entendimento, vale reproduzir o quanto está no $\S 11$ do art. $8^{\circ}$ :

$\S 11$ - O disposto no item 2 do parágrafo anterior também se aplica em relação aos incisos XX a XXIV. 


\section{O LANÇAMENTO NO ICMS}

\subsection{O conceito de lançamento tributário}

Malgrado o tema do lançamento tributário merecidamente desperte o entusiasmo dos estudiosos $^{75}$, não nos cabe examinar o assunto com profundidade: limitar-nos-emos, aqui, a linhas gerais, sempre voltada a atenção para o objetivo central deste trabalho e para a desejável concisão.

Examinado o CTN, entendeu-se que o legislador optara por adotar a teoria dualista da relação obrigacional: a obrigação tributária passaria a existir de imediato com a ocorrência do fato gerador e o crédito tributário findaria constituído tão somente quando do lançamento tributário ${ }^{76}$. Encampara, assim, o modelo romano preconizador da discriminação do debitum, objeto de prestação não coativa, frente a obligatio, elemento coativo da relação. Tratar-se-ia de dois momentos distintos e de institutos essencialmente diversos. Respeitado o entendimento, teríamos que, brotado o debitum, o sujeito passivo da relação obrigacional permaneceria livre: poderia desincumbir-se da prestação, como poderia deixar de lado a incumbência. Somente com a obligatio surgiria o elemento coativo na relação: a partir daí é que se poderia coagir o sujeito passivo a prestar o devido $^{77}$.

Enfim, prosperou a ideia segundo a qual, concretizada a hipótese prevista no antecedente de uma norma geral e abstrata, surgiria, por força da imediata incidência do consequente da mesma norma, uma relação jurídica que se traduziria num vínculo a unir o sujeito ativo ao sujeito passivo, estabelecendo um crédito em favor do primeiro e um

75 Ver, dentre outros: BORGES, José Souto Maior. Lançamento Tributário. 2. ed. São Paulo: Malheiros, 1999; XAVIER, Alberto. Do Lançamento: Teoria Geral do Ato do Procedimento e do Processo Tributário. 2. ed. Rio de Janeiro: Forense, 2001; SANTI, Eurico Marcos Diniz de. Lançamento Tributário. São Paulo: Max Limonad, 1996; HORVATH, Estevão. Lançamento Tributário $e$ “Autolançamento”. São Paulo: Dialética, 1997.

76 Nesse sentido: LACOMBE, Américo Masset. Obrigação Tributária. São Paulo: Revista dos Tribunais, 1977, passim.

77 Ideia diferente é apresentada por Alcides Jorge Costa: “O fato gerador dá nascimento, por si só, à obrigação tributária em seus dois elementos: o dever e a responsabilidade, ainda quando dissociamos um do outro. Portanto, verificando o fato gerador, o sujeito passivo do dever tem que executar uma prestação em favor do sujeito ativo, isto é, do Estado, enquanto este tem o direito de aproveitar-se da prestação devida pelo vendedor. Lembremo-nos agora da figura de ônus, ou seja, do dever de observar, no exercício de um direito subjetivo, uma determinada conduta, ou de acompanhar tal exercício com determinadas ações, com a sanção da perda do direito, em caso de inobservância.". Cf. Contribuição ao Estudo da Obrigação Tributária. São Paulo: IBDT, 2003, p. 49. 
débito em desfavor do segundo - relação esta que equivaleria ao debitum romano -, sucedendo, todavia, que a satisfação do credor, o ente tributante, reclamaria que ele mesmo emitisse uma norma individual e concreta apta para constituir uma relação jurídica de exigibilidade, carregada de coatividade, relação esta que equivaleria à obligatio romana $^{78}$.

Tendo em conta essa ideia - e reportando-se em especial, mas não somente, aos arts. $113, \S 1^{\circ}$, 142 e 144 do CTN - bom número de estudiosos atribuiu caráter de obligatio ao lançamento e imputou-lhe, frente ao debitum, frente à obrigação tributária, natureza declaratória.

Esse o entendimento de AmÉRICo Masset Lacombe. Segundo o A., nascida a relação de débito, o debitum, o lançamento "constitui a relação de responsabilidade", a obligatio. Cuidando-se a relação de débito de relação entre pessoas, escreveu, o lançamento deve reportar-se à data na qual estabelecido o vínculo pessoal, daí seu caráter meramente declaratório ${ }^{79}$.

Vale lembrar - lista nem de longe exaustiva -, dentre os estudiosos que registraram o entendimento de que a natureza do lançamento tributário é meramente declaratória, Rubens Gomes de Sousa ${ }^{80}$, Ruy Barbosa Nogueira ${ }^{81}$, CARlos DA Rocha Guimarães $^{82}$, José Eduardo SoAres de Melo ${ }^{83}$, SACha CAlmon NAVARro CoÊlho ${ }^{84}$, AMÍlCAR DE ARAÚJO FALCÃO ${ }^{85}$ e ESTEVÃo HORVATH ${ }^{86}$

Cf. LACOMBE, Américo Masset. Obrigação Tributária. São Paulo: Revista dos Tribunais, 1977, p. 74.

Cf. Lançamento. In: MARTINS, Ives Gandra da Silva (coord.). Curso de Direito Tributário. 11. ed. São Paulo: Saraiva, 2009, p. 319-342 (p. 330).

80 Escreveu:

"O lançamento é um ato declaratório: com efeito, já sabemos que o nascimento da obrigação tributária decorre do fato gerador (...): o lançamento apenas faz a constatação e a valoração desse fato". Cf. Compêndio de Legislação Tributária. Edição póstuma. São Paulo: Resenha Tributária, 1981, p. 105.

\section{Escreveu:}

"desde logo, podemos acentuar a verdadeira natureza de ato declaratório do lançamento, tendo em vista que uma vez concluído, êle nada mais faz do que declarar, na conformidade da lei material e preexistente, se há um débito tributário, qual o montante devido e quem é o devedor. Opera assim a liquidação do débito, removendo os obstáculos da incerteza e iliquidez, sem o que a Fazenda Pública não pode exigir administrativamente o seu direito creditório e muito menos convocar o Poder Judiciário para a execução forçada.".

Cf. Teoria do Lançamento Tributário. São Paulo: Resenha Tributária, 1973, p. 39.

"Com efeito, seguindo o C.T.N. (art. 114), e também melhor doutrina, a obrigação tributária nasce com a ocorrência do fato gerador; estabelece-se assim um vínculo jurídico, ao quaI deve se amoldar o lançamento (art. 142 e seu parág. e art. 144 do C.T.N.).

Assim sendo, o lançamento é ato meramente declaratório; explicita a obrigação já nascida."

Cf. Lançamento - Natureza e Eficácia. In: MARTINS, Ives Gandra da Silva (Coord.). Caderno de Pesquisas Tributárias. São Paulo, vol. 12, p. 241-247 (p. 244), 1987. 
Nada obstante o merecido respeito que angariou essa corrente doutrinária, entendemos de adotar, no tocante ao lançamento tributário, as lições de PAULO DE BARROS CARvalHo e dos estudiosos que o acompanham.

Segundo o A., "os fatos da chamada realidade social serão simples eventos, enquanto não forem constituídos em linguagem jurídica própria" ${ }^{\circledR 7}$. Via de consequência, só há falar de fato jurídico tributário quando determinado evento ocorrido no mundo social seja vertido em linguagem jurídica competente. Constituído o fato jurídico tributário, instaura-se o vínculo obrigacional, a relação jurídica tributária. Elemento indissociável da obrigação tributária de cunho patrimonial, o crédito tributário só desponta, todavia, com sua formalização, o que "significa verter em linguagem competente o fato e a respectiva relação tributária, objetivando o sujeito ativo, o sujeito passivo e o objeto da prestação, no bojo da norma individual e concreta" ${ }^{\natural 8}$. Bem por isso é que formulou a seguinte definição $^{89}$ :

Lançamento tributário é o ato jurídico administrativo, da categoria dos simples, constitutivos e vinculados, mediante o qual se insere na ordem jurídica brasileira u'a norma individual e concreta, que tem como

“Considerando que o crédito nasce no mesmo instante em que também tem nascimento a obrigação, em virtude da ocorrência do fato gerador, deflui a inexorável natureza "declaratória" do lançamento. O referido ato administrativo não cria o crédito tributário, tendo por objeto declarar todos os aspectos do tributo (sujeitos ativo e passivo, materialidade, base de cálculo e alíquota), indicando o montante devido, com o objetivo de formalizar o crédito tributário, permitindo sua exigibilidade mediante a instituição de título inscrito na dívida ativa (arts. 201 e 202 do CTN)".

Cf. Curso de Direito Tributário. 9. ed. São Paulo: Dialética, 2010, p. 331-332.

Escreveu:

"O lançamento, como ato administrativo de aplicação da lei genérica e abstrata aos casos concretos, deve reportar-se à lei que vigia ao tempo do fato gerador, aplicando-a. Conseqüentemente, a sua função não é, absolutamente, criadora do crédito, senão que declaratória do seu prévio existir nos exatos termos da lei contemporânea ao seu nascimento. $\mathrm{O}$ fato gerador, ao acontecer, instaura a obrigação e o crédito tributário, como prescreve o CTN."

Cf. Curso de Direito Tributário Brasileiro. 10. ed. Rio de Janeiro: Forense, 2009, p. 694.

\section{Escreveu:}

"O efeito resultante do lançamento tem que ver com a exigibilidade da prestação que constitui objeto da obrigação tributária - ou seja, com a exigibilidade do pagamento do tributo.

Quanto ao mais, limita-se o lançamento a reconhecer, valorar qualitativa e quantitativamente, liquidar em suma a obrigação tributária que lhe é preexistente, que nasce quando da ocorrência do fato gerador e que nesse momento mesmo de sua gênese se amolda ao regime normativo e às características fácticas que marcarão definitivamente a sua fisionomia.

É a circunstância mesma de ter a obrigação tributária por energia e momento genetlíacos a ocorrência do fato gerador, que explica o fato de o lançamento, como é próprio dos atos declaratórios, ter efeito retrooperante quanto à pesquisa e determinação dos elementos com base nos quais será fixado o an, o $s i$ e o quantum debeatur."

Cf. Fato Gerador da Obrigação Tributária. 6. ed. Rio de Janeiro: Forense, 1997, p. 55.

86 Cf. Lançamento Tributário e “Autolançamento”. São Paulo: Dialética, 1997, p. 57.

87 Cf. Direito Tributário, Linguagem e Método. 2. ed. São Paulo: Noeses, 2008, p. 426.

$88 \quad$ Idem, p. 431.

89 Cf. Curso de Direito Tributário. 22. ed. São Paulo: Saraiva, 2010, p. 458. 
antecedente o fato jurídico tributário e, como consequente, a formalização do vínculo obrigacional, pela individualização dos sujeitos ativo e passivo, a determinação do objeto da prestação, formado pela base de cálculo e correspondente alíquota, bem como pelo estabelecimento dos termos espaço-temporais em que o crédito há de ser exigido.

A definição é bastante para se compreender que a eficácia do lançamento não é tão somente declaratória, mas também constitutiva, bem assim que não há falar de vínculo obrigacional e crédito em favor do sujeito ativo antes de concretizado o lançamento.

Cabe enumerar - também aqui a lista está longe de ser exaustiva -, dentre os que encamparam o entendimento, ALESSANDRA GONDIM PINHO ${ }^{90}$ e DENISE LUCENA CAvalcante $^{91}$.

\subsection{As modalidades de constituição do crédito tributário}

Consoante o grau de colaboração do sujeito passivo na constituição do crédito tributário, o CTN indica três diversas "modalidades de lançamento": (i) o direto, ou de

90 Escreveu:

"o papel da norma individual e concreta é extremamente relevante no mundo do direito positivo e, em especial, na formação do fato jurídico tributário; afinal, a regra jurídica geral e abstrata só alcança seu inteiro teor de juridicidade se se opera a edição da norma individual e concreta," e só se pode cobrar um tributo se existe uma obrigação tributária devidamente formalizada, isto é, se há uma obrigação jurídica tributária. Impossível imaginar um caso de incidência específica da regra matriz numa hipótese individualizada sem a edição do ato competente, viabilizando-a. Este ato configura a própria norma individual e concreta e pode ser produzido pela entidade tributante ou, nos casos em que a lei permite, pelo próprio contribuinte. É o denominado lançamento tributário ou o 'ato-norma formalizador da obrigação tributária', respectivamente."

Cf. Fato Jurídico Tributário. São Paulo: Max Limonad, 2001, p. 67-68.

91 Escreveu: "O direito tributário brasileiro teve forte influência da doutrina alemã e da italiana, justificando, hoje, uma série de normas no Código Tributário Nacional, tal qual a que afirma que a obrigação tributária surge com o fato gerador. Porém, a obrigação tributária, analisada sob o prisma jurídico, e não como uma mera probabilidade, não surge com o fato gerador, mas sim com o ato administrativo do lançamento ou com o ato jurídico emanado do cidadão-contribuinte.

Para sustentar esta posição adotaram-se as seguintes premissas: (i) exigibilidade e existência do direito são momentos idênticos e simultâneos, não justificando a diferença conceitual entre ambos; (ii) não há obrigação sem crédito, e vice-versa - ou seja, ambos têm a mesma natureza, a mesma função, e fazem parte da mesma fase da dinâmica da relação tributária; (iii) o direito é um vínculo jurídico entre pessoas, daí a intersubjetividade fazer parte da essência do direito. Então, enquanto não há este vínculo, não há relação jurídica; (iv) o dogma da incidência automática e infalível decorrente do fato gerador não corresponde à realidade; (v) a eficácia é propriedade do fato jurídico; (vi) só é possível falar em existência da obrigação tributária se a relação já estiver constituída, ou seja, se já existe o respectivo crédito. Antes disto não há nem relação jurídica, nem obrigação tributária, nem crédito tributário, nem débito a cobrar, porque o evento não foi juridicizado, ou seja, não entrou no mundo jurídico; (vii) a dinâmica da relação tributária explicada em dois momentos obrigação e crédito - é uma teoria inadequada, pois pretende forçar a existência de uma obrigação vazia de sentido."

Cf. Crédito Tributário. São Paulo: Malheiros, 2004, p. 130-131. 
ofício, previsto no seu art. 149, (ii) o misto, ou por declaração, previsto no seu art. 147 e (iii) o lançamento por homologação, ou autolançamento ${ }^{92}$, previsto no seu art. 150.

No lançamento de ofício, ou direto, a autoridade administrativa constitui o crédito tributário sem que o sujeito passivo lhe preste nenhuma colaboração. É o caso, por exemplo, do imposto que, de competência Municipal, incide sobre a propriedade predial e territorial urbana, tributo este previsto no art. 156, inc. I, da CF de 1988.

No lançamento por declaração, ou misto, o sujeito passivo coloca à disposição da autoridade tributária informações a respeito do fato imponível, informações estas que darão base à mesma autoridade para que constitua o crédito tributário.

No lançamento por homologação, ou autolançamento, a "colaboração" do sujeito passivo na constituição do crédito tributário atinge grau máximo; na realidade observável, a interveniência do ente tributante na constituição do crédito tributário é nenhuma ${ }^{93}$.

Como assinala PAUlo de BARros CARvalho, no chamado lançamento por homologação "a lei dá competência ao contribuinte para constituir o fato jurídico e a obrigação tributária que dele decorre", cabendo-lhe "seguir os comandos da lei, implementando os deveres instrumentais previstos, com o preenchimento de formulários e documentos específicos para, desse modo, estruturar a norma individual e concreta que lhe corresponda expedir" ${ }^{\prime 4}$ - o que possibilita se faça o recolhimento do tributo sem que a autoridade administrativa tenha que despender esforços -, não passando a homologação, de "um ato de fiscalização, como tantos outros, em que o Estado, zelando pela integridade de seus interesses, verifica o procedimento do particular, manifestando-se expressa ou tacitamente sobre ele" $" 95$. Enfim, muito embora o que está no art. 142 do CTN diga com ato jurídico privativo da autoridade administrativa, a tanto equivale o ato por meio do qual o sujeito passivo expede a norma individual e concreta, daí que, segundo o A., "nada custaria ao legislador brasileiro chamar a ambos os atos - o praticado pelo fisco (lançamento) e o

92 É o vocábulo mais adequado à espécie, no entender de Estevão Horvath. Cf. Lançamento Tributário e “Autolançamento". São Paulo: Dialética, 1997, passim.

93 Digno de menção, a respeito do tema, o pensamento de Gilberto de Ulhôa Canto: "É equivoco supor que o CTN fez, na matéria, uma profissão de fé no sentido de que só pode haver lançamento mediante a prática de atos pela autoridade administrativa, e que em função disso é contraditório e inconciliável com aquele princípio admitir - corno o fez no art. 150 - urna forma diferente de apuração do montante do tributo e do seu pagamento pelo próprio sujeito passivo, sem dependência de atuação prévia do Fisco.”. Cf. O Lançamento. In: MARTINS, Ives Gandra da Silva (Coord.). Caderno de Pesquisas Tributárias. São Paulo. v. 12, p. 1-23 (p. 19), 1987.

94 Cf. Direito Tributário: fundamentos jurídicos da incidência. 8. ed. São Paulo: Saraiva, 2010, p. 327.

95 Idem, p. 329. 
realizado pelo contribuinte - pelo mesmo nome, apenas acrescendo um prefixo ou sufixo que pudesse diferençá-los quanto à autoria" 96 .

Denise Lucena Cavalcante pensa do mesmo modo. Sustenta a A. que o crédito tributário pode ser constituído tanto pelo lançamento de que se cuida no art. 142 do CTN quanto pelo próprio "cidadão-contribuinte" - e, reportando-se ao art. 150, § 1º, do CTN, que entende maculado de termos imprecisos, afirma que no chamado lançamento por homologação, ou autolançamento, na verdade não há lançamento nenhum, sendo certo que a homologação diz respeito tão só ao pagamento a que se faz menção no dispositivo, nada mais $^{97}$.

Seguro que o entendimento de Paulo de Barros Carvalho e de Denise Lucena CAVAlCANTE acerca da matéria não é endossado por todos os estudiosos. Apresentam-se discrepantes, dentre outras, as ideias de LUCIANO AMARO ${ }^{98}$ e GERALDO ATALIBA ${ }^{99}$. É o que ensinam os dois primeiros, no entanto, o que esposaremos no bojo deste trabalho.

$96 \quad$ Idem, p. 328.

97 O quanto escreveu a A. merece reprodução:

"O lançamento previsto no art. 142 do Código Tributário Nacional não é a única forma de constituir o crédito tributário. A autoridade administrativa constitui o crédito tributário através do lançamento, mas isto não quer dizer que o crédito só possa ser constituído pelo lançamento.

O fato de o cidadão-contribuinte não poder efetuar o lançamento não significa que ele não possa constituir o crédito tributário; com esta afirmação chega-se a outra, qual seja, a existência de tributos sem lançamento.

A classificação do lançamento no Código Tributário Nacional - lançamento de ofício, por declaração e por homologação - não prospera, vez que, atualmente, as formas de constituição do crédito tributário tanto podem ser pelo lançamento ou por ato do sujeito passivo.

No caso do chamado autolançamento, ou lançamento por homologação, conforme previsto no art. 150, $\S 1^{\circ}$, do Código Tributário Nacional, há uma imprecisão na terminologia do legislador, pois o que se homologa não é o lançamento (que nem houve), mas, sim, o pagamento efetuado pelo cidadãocontribuinte.".

Cf. Crédito Tributário. São Paulo: Malheiros, 2004, p. 132.

Escreveu o A.:

"Como o lançamento - ato da autoridade administrativa - é condição de exigibilidade do tributo, enquanto ele não é praticado, corre o prazo de decadência, ainda que o sujeito passivo tenha escriturado operações, emitido notas, prestado informações ao Fisco ou mesmo apresentado declarações à autoridade fiscal. Nada disso substitui o ato de lançamento, dado que este é, por definição e exigência legal, um ato (ou atividade) privativo da autoridade administrativa. Só com a prática desse ato (e sua notificação ao sujeito passivo) tem-se por "constituído o crédito tributário" (linguagem com a qual o Código confere exigibilidade à obrigação tributária nascida com o fato gerador). É o crédito tributário assim "constituído" que, se não satisfeito, será objeto de inscrição, assumindo aí, como vimos, a condição de "dívida ativa tributária", com o que a obrigação tributária adquire executoriedade, isto é, aptidão para instrumentar-se como título executivo e ser objeto de ação de execução.”.

Cf. Lançamento, essa Formalidade! In: TÔRRES, Heleno Taveira (Coord.). Teoria Geral da Obrigação Tributária - Estudos em Homenagem ao Professor José Souto Maior Borges. São Paulo: Malheiros, 2005. p. 374-390 (p. 377).

99 Escreveu o A.:

"O lançamento por homologação - impropriamente chamado auto-lançamento - ocorre quando a lei atribui ao sujeito passivo a incumbência de todo o preparo material e técnico do ato, que, destarte, se reduz a uma simples homologação. 
Convém assinalar, neste passo, que a constituição do crédito tributário, no tocante ao ICMS, é espécie do gênero dado como "lançamento por homologação" pelo art. 150 do $\mathrm{CTN}^{100}$. Esta a regra geral, somente cabendo o lançamento de ofício do art. 149 do mesmo diploma em casos excepcionais, quais sejam aqueles nos quais o sujeito passivo deixe de se conduzir de acordo com o previsto no primeiro dispositivo citado ${ }^{101}$.

\subsection{Os momentos nos quais ingressam no sistema a regra individual e concreta engendrada pela Administração e a produzida pelo sujeito passivo}

Tratando-se de ato administrativo introdutor de norma individual e concreta no ordenamento positivo, o lançamento passa a integrar o sistema assim que dele tome ciência o destinatário ${ }^{102}$. Nada obstante possa tornar-se alvo de impugnação e mais adiante modificado, é ato administrativo definitivo desde o momento no qual o destinatário dele tenha conhecimento.

O mesmo se dá, mutatis mutandis, com relação à norma individual e concreta tirada pelo sujeito passivo das imposições tributárias: ingressa no sistema do direito positivo assim que o ente tributante tome ciência do conteúdo do documento que, especificado na pertinente legislação, cabe ao sujeito passivo elaborar com o fim de apresentar, de modo

O lançamento persiste sendo ato privativo do fisco. O contribuinte é mero preparador. O lançamento, propriamente dito, no caso, consiste na homologação."

Cf. Apontamentos de Ciências das Finanças, Direito Financeiro e Tributário. São Paulo: RT, 1969, p. 287-288.

100 Nesse sentido, inter plures: BORGES, José Souto Maior. A Constitucionalidade do Convênio ICM 07/77 e a Inexistência do Direito de Crédito do Substituto, no Diferimento do ICM. Revista de Direito Tributário, n. 6, ano II, p. 87-100 (p. 90), out./dez. 1978; BORGES, José Souto Maior. Lançamento Tributário. 2 ed. São Paulo: Malheiros, 1999, p. 389-393; BONILHA, Paulo Celso Bergstrom. Lançamento do ICM. In: MARTINS, Ives Gandra da Silva (Coord.). Curso de Direito Tributário. São Paulo: Saraiva, 1982, p. 349-356; CARVALHO, Paulo de Barros. Curso de Direito Tributário. 22. ed. São Paulo: Saraiva, 2010, p. 501-504; MARQUES JÚNIOR, Álvaro de Azevedo. O ICM e o Correspondente Crédito na Constituição. Revista de Direito Tributário, São Paulo, n. 21/22, p. 57-77 (p. 73), jul./dez. 1982; LACOMBE, Américo Masset. Lançamento. In: MARTINS, Ives Gandra da Silva (Coord.). Curso de Direito Tributário. 11. ed. São Paulo: Saraiva, 2009, p. 319-341 (p. 340-341).

101 Nesse sentido, inter plures: CARVALHO, Paulo de Barros. Curso de Direito Tributário. 22. ed. São Paulo: Saraiva, 2010, p. 504; BORGES, José Souto Maior. A constitucionalidade do Convênio ICM $07 / 77$ e a Inexistência do Direito de Crédito do Substituto, no Diferimento do ICM. Revista de Direito Tributário, n. 6, ano II, p. 87-100 (p. 90), out./dez. 1978.

102 Cf. CARVALHO, Paulo de Barros. Direito Tributário: Fundamentos Jurídicos da Incidência. 8. ed. São Paulo: Saraiva, 2010, p. 319 
sumulado, o quanto extraído de seus documentos e registros contábeis e fiscais. Antes disso, não há como se dar a norma individual e concreta por construída ${ }^{103}$.

O quanto afirmado no parágrafo precedente foi alvo de controvérsia, entendendo autoridades administrativas que a simples apresentação de tais documentos sumulares não era bastante para que se desse o crédito tributário como constituído, o que não ocorreria antes de proceder-se à homologação prevista no art. 150 do CTN.

A questão parece encontrar-se definitivamente resolvida pelo STJ, haja vista o quanto se decidiu no julgamento do qual tirada a seguinte ementa ${ }^{104}$, aqui apresentada com grifo nosso:

\section{TRIBUTÁRIO. TRIBUTO DECLARADO PELO CONTRIBUINTE E PAGO COM ATRASO. DENÚNCIA ESPONTÂNEA. NÃO CARACTERIZAÇÃO. SÚMULA 360/STJ.}

1. Nos termos da Súmula 360/STJ, "O benefício da denúncia espontânea não se aplica aos tributos sujeitos a lançamento por homologação regularmente declarados, mas pagos a destempo". É que a apresentação de Declaração de Débitos e Créditos Tributários Federais - DCTF, de Guia de Informação e Apuração do ICMS - GIA, ou de outra declaração dessa natureza, prevista em lei, é modo de constituição do crédito tributário, dispensando, para isso, qualquer outra providência por parte do Fisco. Se o crédito foi assim previamente declarado e constituído pelo contribuinte, não se configura denúncia espontânea (art. 138 do CTN) o seu posterior recolhimento fora do prazo estabelecido.

103 Idem, p. 330- 331. Merece transcrição:

"O cumprimento dos deveres instrumentais ou formais, cometidos ao sujeito passivo das imposições tributárias, forma um tecido de linguagem que, na sua integridade, relata o acontecimento de eventos e a instalação de relações jurídicas obrigacionais. Poder-se-ia pensar, então, que a satisfação desses deveres, já que se afiguram como linguagem competente em face da lei, bastaria para dar-se por construída a norma individual e concreta.

Não é assim, contudo. A regra jurídica individual e concreta, quando ficar a cargo do contribuinte, há de constar de um documento especificamente determinado em cada legislação, e que consiste numa redução sumular, num resumo objetivo daquele tecido de linguagem, mais amplo e abrangente, constante dos talonários de notas fiscais, livros e outros efeitos jurídico-contábeis. O documento da norma há de ter, além da objetividade que mencionei, o predicado da unidade de sentido, uma vez que expressa enunciados prescritivos, a partir dos quais o intérprete fará emergir a norma individual e concreta.

Sobremais, recuperando a premissa de que o direito se realiza no contexto de um grandioso processo comunicacional, impõe-se a necessidade premente de o documento do qual falamos seja oferecido à ciência da entidade tributante, segundo a forma igualmente prevista no sistema positivo. De nada adiantaria ao contribuinte expedir o suporte físico que contém tais enunciados prescritivos, sem que o órgão público, juridicamente credenciado, viesse a saber do expediente. $O$ átimo dessa ciência marca $o$ instante preciso em que a norma individual e concreta, produzida pelo sujeito passivo, ingressa no ordenamento do direito posto."

104 Disponível em <http://www.stj.jus.br>. Acesso em 24 out 2010. 
2. Recurso especial desprovido. Recurso sujeito ao regime do art. 543-C do CPC e da Resolução STJ 08/08.

(REsp 962379/RS, Rel. Ministro Teori Albino Zavascki, Primeira Seção, julgado em 22/10/2008, DJe 28/10/2008)

Importante frisar que se trata de decisão proferida nos autos de recurso especial processado nos termos do art. 543-C do $\mathrm{CPC}^{105}$, daí que irradiou efeitos consideráveis para a banda dos casos nos quais debatida a mesma matéria, ao demais de veicular entendimento que dificilmente será alterado, desde que mantida a legislação do modo que está.

\subsection{O lançamento na $\operatorname{LC} n^{0} 87 / 96$}

Na sua redação atual, a LC n ${ }^{\circ}$ 87/96 não faz uso do vocábulo lançamento a não ser no seu art. $20, \S 5^{\circ}, \mathrm{VI}$, que trata da escrituração de créditos de ICMS "decorrentes de

105 Art. 543-C - Quando houver multiplicidade de recursos com fundamento em idêntica questão de direito, o recurso especial será processado nos termos deste artigo. (Incluído pela Lei $\mathrm{n}^{\circ} 11.672$, de 8 de maio de 2008).

$\S 1^{\circ}$ Caberá ao presidente do tribunal de origem admitir um ou mais recursos representativos da controvérsia, os quais serão encaminhados ao Superior Tribunal de Justiça, ficando suspensos os demais recursos especiais até o pronunciamento definitivo do Superior Tribunal de Justiça. (Incluído pela Lei $\mathrm{n}^{\circ} 11.672$, de 8 de maio de 2008).

$\S 2^{\circ}$ Não adotada a providência descrita no $\S 1^{\circ}$ deste artigo, o relator no Superior Tribunal de Justiça, ao identificar que sobre a controvérsia já existe jurisprudência dominante ou que a matéria já está afeta ao colegiado, poderá determinar a suspensão, nos tribunais de segunda instância, dos recursos nos quais a controvérsia esteja estabelecida. (Incluído pela Lei ${ }^{\circ} 11.672$, de 8 de maio de 2008).

$\S 3^{\circ} \mathrm{O}$ relator poderá solicitar informações, a serem prestadas no prazo de quinze dias, aos tribunais federais ou estaduais a respeito da controvérsia. (Incluído pela Lei $\mathrm{n}^{\circ} 11.672$, de 8 de maio de 2008).

$\S 4^{\circ} \mathrm{O}$ relator, conforme dispuser o regimento interno do Superior Tribunal de Justiça e considerando a relevância da matéria, poderá admitir manifestação de pessoas, órgãos ou entidades com interesse na controvérsia. (Incluído pela Lei $\mathrm{n}^{\circ} 11.672$, de 8 de maio de 2008).

$\S 5^{\circ}$ Recebidas as informações e, se for o caso, após cumprido o disposto no $\S 4^{\circ}$ deste artigo, terá vista o Ministério Público pelo prazo de quinze dias. (Incluído pela Lei no 11.672, de 8 de maio de 2008).

$\S 6^{\circ}$ Transcorrido o prazo para o Ministério Público e remetida cópia do relatório aos demais Ministros, o processo será incluído em pauta na seção ou na Corte Especial, devendo ser julgado com preferência sobre os demais feitos, ressalvados os que envolvam réu preso e os pedidos de habeas corpus. (Incluído pela Lei $n^{\circ} 11.672$, de 8 de maio de 2008).

$\S 7^{\circ}$ Publicado o acórdão do Superior Tribunal de Justiça, os recursos especiais sobrestados na origem: (Incluído pela Lei $\mathrm{n}^{\mathrm{o}} 11.672$, de 8 de maio de 2008).

I - terão seguimento denegado na hipótese de o acórdão recorrido coincidir com a orientação do Superior Tribunal de Justiça; ou (Incluído pela Lei nº 11.672, de 8 de maio de 2008).

II - serão novamente examinados pelo tribunal de origem na hipótese de o acórdão recorrido divergir da orientação do Superior Tribunal de Justiça. (Incluído pela Lei no ${ }^{\circ} 1.672$, de 8 de maio de 2008).

$\S 8^{\circ} \mathrm{Na}$ hipótese prevista no inciso II do $\S 7^{\circ}$ deste artigo, mantida a decisão divergente pelo tribunal de origem, far-se-á o exame de admissibilidade do recurso especial. (Incluído pela Lei no 11.672 , de 8 de maio de 2008).

$\S 9^{\circ}$ O Superior Tribunal de Justiça e os tribunais de segunda instância regulamentarão, no âmbito de suas competências, os procedimentos relativos ao processamento e julgamento do recurso especial nos casos previstos neste artigo. (Incluído pela Lei nº 11.672, de 8 de maio de 2008). 
entrada de mercadorias no estabelecimento destinadas ao ativo permanente"106. Mais: examinado seu texto na íntegra, observa-se que nada dispõe expressamente a respeito de momento no qual se deva proceder ao "lançamento" do ICMS. Nada obstante, detém-se em atribuir aos Estados competência bastante para legislar sobre regimes de apuração do imposto. Vejamos.

\subsubsection{Os regimes de apuração previstos na $L C n^{\circ} 87 / 96$}

É do art. $24^{107}$ da LC no $87 / 96$ que a legislação tributária estadual disporá sobre o período de apuração do imposto, no encerramento do qual serão consideradas vencidas as obrigações, devendo estas obrigações ser liquidadas por meio de compensação, ou de pagamento em dinheiro. $\mathrm{Na}$ compensação, serão tomados em conta, de uma banda, os débitos do imposto e, de outra banda, os créditos escriturados no período, somados estes, se houver, do saldo credor referente a período ou períodos anteriores. Na hipótese de se verificar montante de débitos superior ao de créditos, "a diferença será liquidada dentro do prazo fixado pelo Estado"; caso contrário, "a diferença será transportada para o período seguinte".

106 Art. 20 - Para a compensação a que se refere o artigo anterior, é assegurado ao sujeito passivo o direito de creditar-se do imposto anteriormente cobrado em operações de que tenha resultado a entrada de mercadoria, real ou simbólica, no estabelecimento, inclusive a destinada ao seu uso ou consumo ou ao ativo permanente, ou o recebimento de serviços de transporte interestadual e intermunicipal ou de comunicação.

(omissis)

$\S 5^{\circ}$ Para efeito do disposto no caput deste artigo, relativamente aos créditos decorrentes de entrada de mercadorias no estabelecimento destinadas ao ativo permanente, deverá ser observado: (Redação dada pela $\operatorname{LCP~}^{\circ} 102$, de 11.7.2000)

(omissis)

VI - serão objeto de outro lançamento, além do lançamento em conjunto com os demais créditos, para efeito da compensação prevista neste artigo e no art. 19, em livro próprio ou de outra forma que a legislação determinar, para aplicação do disposto nos incisos I a V deste parágrafo; e (Inciso incluído pela $L C n^{\circ} 102$, de 11 de julho de 2000)

107 Art. 24. A legislação tributária estadual disporá sobre o período de apuração do imposto. As obrigações consideram-se vencidas na data em que termina o período de apuração e são liquidadas por compensação ou mediante pagamento em dinheiro como disposto neste artigo:

I - as obrigações consideram-se liquidadas por compensação até o montante dos créditos escriturados no mesmo período mais o saldo credor de período ou períodos anteriores, se for o caso;

II - se o montante dos débitos do período superar o dos créditos, a diferença será liquidada dentro do prazo fixado pelo Estado;

III - se o montante dos créditos superar os dos débitos, a diferença será transportada para o período seguinte.

II - sejam transferidos, nas condições que definir, a outros contribuintes do mesmo Estado. 
No seu art. $26^{108}$, a LC no $87 / 96$ dispõe que a lei estadual poderá estabelecer regimes de apuração diversos daquele previsto no seu art. 24 - e enumera as seguintes hipóteses: (i) apuração na qual o confronto de créditos e débitos "se faça por mercadoria ou serviço dentro de determinado período", (ii) apuração na qual o confronto de créditos e débitos "se faça por mercadoria ou serviço em cada operação" e (iii) apuração na qual, considerado certo lapso de tempo, a importância devida a título de imposto será fixada por estimativa e paga em parcelas periódicas.

O exame dessas disposições permite concluir que as diretrizes assentadas pelo legislador complementar dizem com dois grupos. No primeiro, conferiu à legislação tributária competência para fixar regime de apuração vinculado ao tempo. No segundo, atribuiu ao legislador ordinário - e somente a ele, já que empregou o vocábulo lei, e não a expressão legislação tributária - a faculdade de estabelecer regime de apuração vinculado (i) ao tempo, considerada determinada mercadoria, ou determinado serviço, ou (ii) a determinada operação, ou determinado serviço, ou (iii) a uma estimativa na qual, "em função do porte ou da atividade do estabelecimento", há de ser quantificado o imposto $a$ pagar.

Esclareçamos qual seja o motivo embasador dessas anotações.

É truísmo afirmar que somente com a apuração, não importa qual seja o método para tanto empregado, passa o agente econômico a ter conhecimento de qual seja o montante que deverá levar aos cofres públicos, ou de conhecer qual seja montante do saldo credor a ele mesmo favorável. Respeitada a premissa, todavia, de que somente com a ciência, por parte do ente tributante, da norma individual e concreta tirada pelo sujeito passivo se instaura a obrigação tributária e se constitui o crédito tributário, ou se constitui o saldo credor favorável ao sujeito passivo, a apuração, isoladamente, não implica

108 Art. 26 - Em substituição ao regime de apuração mencionado nos arts. 24 e 25, a lei estadual poderá estabelecer:

I - que o cotejo entre créditos e débitos se faça por mercadoria ou serviço dentro de determinado período;

II - que o cotejo entre créditos e débitos se faça por mercadoria ou serviço em cada operação;

III - que, em função do porte ou da atividade do estabelecimento, o imposto seja pago em parcelas periódicas e calculado por estimativa, para um determinado período, assegurado ao sujeito passivo o direito de impugná-la e instaurar processo contraditório.

$\S 1^{\circ} \mathrm{Na}$ hipótese do inciso III, ao fim do período, será feito o ajuste com base na escrituração regular do contribuinte, que pagará a diferença apurada, se positiva; caso contrário, a diferença será compensada com o pagamento referente ao período ou períodos imediatamente seguintes.

$\S 2^{\circ} \mathrm{A}$ inclusão de estabelecimento no regime de que trata o inciso III não dispensa o sujeito passivo do cumprimento de obrigações acessórias. 
reconhecer que há credor e devedor. Serve a apuração, apenas, de elemento embrionário a partir do qual caberá ao sujeito passivo produzir a norma individual e concreta que, esta sim, ao depois de conhecida pelo ente tributante, firmará a existência de uma obrigação tributária de cunho patrimonial.

Com a apuração, enfim, ainda não está o ente tributante na possibilidade de se dizer credor - e, via de consequência, não reúne as condições necessárias para proceder a nenhuma cobrança.

Sucede, todavia, que o exame dos regimes de apuração relativos ao ICMS talvez possa fornecer elementos para que se alcance conhecer quais sejam os momentos nos quais o sujeito passivo do imposto há de proceder ao quanto necessário para a constituição do crédito tributário. É o que logo veremos.

\subsection{O lançamento na Lei $n^{0} 6.374 / 89$}

O mesmo que registramos em relação à $\operatorname{LC} \mathrm{n}^{\circ}$ 87/96 é de se dizer da Lei $n^{\circ}$ 6.374/89: não fixa expressamente qual seja o momento no qual é de se proceder ao "lançamento" do imposto. Nada obstante, vale a pena examinar quais sejam os regimes de apuração previstos no diploma e verificar se, desse exame, é possível saber qual seja o momento no qual há de se constituir o crédito tributário.

\subsubsection{A constituição do crédito tributário no regime periódico de apuração}

A Lei ${ }^{\circ}$ 6374/89 estabelece:

a) no seu art. $35^{109}$, que o lançamento do ICMS, "é feito nos documentos e nos livros fiscais com a descrição da operação ou prestação, na forma prevista em regulamento", tratando-se de "atividade de exclusiva responsabilidade do contribuinte, ficando sujeita a posterior homologação pela autoridade administrativa";

109 Artigo 35 - O lançamento do imposto é feito nos documentos e nos livros fiscais com a descrição da operação ou prestação, na forma prevista em regulamento.

Parágrafo único - Essa atividade é de exclusiva responsabilidade do contribuinte, ficando sujeita a posterior homologação pela autoridade administrativa. 
b) no seu art. $48^{110}$, que o imposto a recolher, tratando-se de "estabelecimento de contribuinte obrigado à escrituração fiscal"", deverá ser apurado de conformidade com regime periódico de apuração, período de tempo este que será fixado no pertinente regulamento;

c) no seu art. $49^{112}$, que o estabelecimento enquadrado no regime periódico de apuração deverá, isto no último dia do período, apurar quais sejam os somatórios de (c.1) débitos e (c.2) créditos do imposto e, a partir desses resultados, quantificar (c.3) o montante do ICMS a recolher, recolhimento que deverá ter lugar no prazo fixado em regulamento, ou (c.4) do saldo credor a ser transportado para o período seguinte;

110 Artigo 48 - O estabelecimento de contribuinte obrigado à escrituração fiscal deve apurar o valor do imposto a recolher, de conformidade com os seguintes regimes:

I - regime periódico de apuração;

II - regime de estimativa.

Parágrafo único - O período de apuração dos regimes referidos neste artigo será fixado em regulamento. (Redação dada ao parágrafo pela Lei 9.329/95, de 26-12-1995; DOE 27-12-1995).

111 Poucos são, dentre os submetidos à legislação do ICMS paulista, os que escapam de "escrituração fiscal" obrigatória. A título de exemplo: o produtor não está obrigado a escriturar livros fiscais; caso queira, nada obstante, tirar proveito de créditos de ICMS, deverá escriturar Livro Registro de Entradas (RICMS, art. 213, § 12, e Portaria CAT n ${ }^{\circ} 17 / 2002$, art. 16). Outro exemplo: salvo quanto ao Registro de Utilização de Documentos Fiscais e Termos de Ocorrências, à escrituração dos demais livros fiscais não está obrigada a empresa de construção civil que se dedicar exclusivamente à prestação de serviços e não efetuar operações de circulação de mercadoria, ainda que movimente máquinas, veículos, ferramentas ou utensílios (RICMS/00, Anexo XI, art. $5^{\circ}$, parágrafo único).

112 Artigo 49 - O estabelecimento enquadrado no regime periódico de apuração, no último dia do período e na forma prevista em regulamento, deve apurar nos livros fiscais próprios:

I - os valores das operações de saída de mercadoria e das prestações de serviço e o correspondente débito do imposto;

II - os valores das operações de entrada de mercadoria e das prestações de serviços tomados e o correspondente crédito do imposto;

III - os valores de outros débitos ou créditos do imposto;

IV - os valores de estornos de débitos e de créditos de imposto;

$\mathrm{V}$ - o valor do imposto a recolher; ou

VI - o valor do saldo credor a transportar para o período seguinte.

$\S 1^{\circ}$ - Os valores referidos nos incisos V e VI devem ser declarados ao fisco.

$\S 2^{\circ}-\mathrm{O}$ montante mencionado no inciso $\mathrm{V}$ deve ser recolhido na forma e nos prazos fixados em regulamento.

$\S 3^{\circ}$ - Nos casos em que incumba ao destinatário o pagamento do imposto relativo à entrada de mercadoria em seu estabelecimento ou ao recebimento de serviço, o regulamento poderá dispor que o recolhimento se faça independentemente do resultado da apuração do imposto no período correspondente.

$\S 4^{\circ}$ - O recolhimento do imposto retido por contribuinte, na qualidade de sujeito passivo por substituição, deve ser efetuado independentemente do resultado da apuração relativa às operações ou prestações realizadas pelo estabelecimento no período, conforme disposto em regulamento.

$\S 5^{\circ}$ - O regulamento poderá estabelecer que o saldo credor do imposto de que trata o inciso VI, em substituição ao transporte do valor para o período seguinte, possa ser utilizado para liquidação de débito fiscal, não vencido, relativo a saldo devedor apurado de período anterior, do mesmo mês. (Parágrafo acrescentado pela Lei 9.359/96, de 18-06-1996; DOE 19-06-1996; Efeitos a partir de 01-02-1994) 
d) no seu art. $56^{113}$, que o inscrito no Cadastro de Contribuintes do ICMS ${ }^{114}$ tem o dever de noticiar, por meio de guia de informação, os valores (d.1) das operações ou prestações, (d.2) do imposto a recolher ou, se for o caso (d.3) do saldo credor a transportar para o período seguinte;

e) na cabeça do seu art. 62, que o imposto devido, declarado e não pago deve ser inscrito na Dívida Ativa, após 60 (sessenta) dias contados do vencimento.

Essas, em linhas gerais, as regras que disciplinam o que se chama regime periódico de apuração. Observa-se que nessa forma de apuração cabe ao sujeito passivo providenciar ele mesmo, no último dia do período, a quantificação do tributo a recolher, ou do saldo credor a ser transportado para o período seguinte. Isso impõe que o agente econômico mantenha escrituração fiscal na qual registre, à semelhança de uma conta-corrente, (i) o valor do imposto devido em consequência das operações que promover, ou dos serviços que, tributados pelo ICMS, prestar no período - conjunto ao qual a Lei $n^{\circ}$ 6.374/89 atribui o nome de débitos -, e o valor do imposto cobrado nas operações nas quais funcionou como destinatário de mercadorias, ou tomador de serviços tributados pelo ICMS, conjunto ao qual a Lei $\mathrm{n}^{\circ}$ 6.374/89 dá o nome de créditos. Ao final do período, o somatório de débitos, de um lado, e o somatório de créditos, de outro lado, são objeto de uma soma algébrica, cujo resultado, se maiores os débitos do que os créditos, dará a conhecer o montante a ser recolhido à guisa de tributo aos cofres públicos, mas, se maiores os créditos

113 Artigo 56 - Nas hipóteses previstas na legislação, a pessoa inscrita no Cadastro de Contribuintes deve declarar em guia de informação, conforme modelo aprovado pela Secretaria da Fazenda, os valores das operações ou prestações, do imposto a recolher ou, em sendo a hipótese, do saldo credor a transportar para o período seguinte. (Redação dada ao artigo pela Lei 10.619/00, de 19-07-2000; DOE 20-07-2000)

114 Conjunto do qual não escapa nenhum sujeito passivo do imposto que deva ter em conta o regime periódico de apuração. Na realidade, todos quantos se deem à prática de operações relativas a circulação de mercadorias devem inscrever-se no Cadastro de Contribuintes, a teor do constante do art. 16 da Lei $\mathrm{n}^{\circ} 6.374 / 89$, cujo teor é o seguinte:

Artigo 16 - Devem inscrever-se no cadastro de contribuintes, mantido pela Secretaria da Fazenda, antes do início de suas atividades:

I - as pessoas de que trata o "caput" do artigo $7^{\circ}$;

II - a empresa de armazém geral, de armazém frigorífico, de silo e de outros armazéns de depósito de mercadorias;

III - o representante comercial e o mandatário mercantil;

IV - aquele que em propriedade alheia produza e promova saída de mercadoria em seu próprio nome;

$\mathrm{V}$ - aquele que preste, mediante utilização de bem pertencente a terceiro, serviços de transporte interestadual e intermunicipal e de comunicação;

VI - as demais pessoas naturais ou jurídicas de direito público ou privado, que pratiquem habitualmente, em nome próprio ou de terceiro, operações relativas à circulação de mercadoria e ao serviço de transporte interestadual e intermunicipal e de comunicação.

(Quanto à remissão, no inc. I, à cabeça do art. $7^{\circ}$ da mesma Lei: cuida-se do dispositivo no qual apontados quais sejam os contribuintes do ICMS). 
do que os débitos, revelará o montante - saldo credor, segundo está na Lei nº 6.374/89 - a ser aproveitado pelo agente econômico no período seguinte.

Muito embora entrando no campo do óbvio, é importa sublinhar: no tocante ao conjunto de operações e prestações cuja tributação há de levar em conta o regime periódico de apuração, a Lei $n^{\circ}$ 6.374/89 não permite que nada seja cobrado, a título de ICMS, antes do último dia do período.

O que nos interessa mais, no entanto, é saber qual seja o momento no qual, considerado o regime periódico de apuração, é de se constituir o crédito tributário, ou, como está na legislação, o momento no qual há de se proceder ao lançamento do imposto.

Pois bem: o agente econômico submetido ao regime periódico de apuração, ao depois de encerrados período e apuração, deve dar notícia à Fazenda Pública do resultado que encontrou, isto por meio da apresentação de guia de informação específica para tanto. Não basta que simplesmente pague o que eventualmente for devido: a apresentação da guia de informação é imprescindível, tanto assim que, deixando de apresentá-la, ou apresentando-a fora do prazo previsto no RICMS $/ 00^{115}$, será dado como autor de infração administrativa - e apenado com uma das multas previstas no art. 85, inc. VII, al. "a" da Lei $\mathrm{n}^{\mathrm{o}} 6.374 / 89^{116}$, conforme o caso.

115 A regra geral é a prevista no art. 254 do RICMS/00, cuja redação é a seguinte:

Artigo 254 - Salvo disposição em contrário, a guia de informação será entregue no mês subseqüente ao da apuração e até os dias a seguir indicados, de acordo com o último algarismo do número de inscrição estadual do estabelecimento (Lei 6.374/89, art. 56, com alteração da Lei 10.619/00, art. $1^{\circ}$, XXIII; Convênio de 15-12-70 - SINIEF, arts. 80 e 81, ambos na redação do Ajuste SINIEF-1/96, cláusula primeira, II, o primeiro com alteração do Ajuste SINIEF-7/96; Ajuste SINIEF-4/93, cláusulas oitava, parágrafo único, e décima, na redação do Ajuste SINIEF-9/98):

I - finais 0 e 1 - até o dia 11 ;

II - finais 2,3 e 4 - até o dia 12 ;

III - finais 5,6 e 7 - até o dia 13 ;

IV - finais 8 e 9 - até o dia 14.

Parágrafo único - O contribuinte de outra unidade federada que, na condição de responsável, efetuar retenção do imposto a favor deste Estado, deverá apresentar, até o dia 10 do mês subseqüente ao da apuração do imposto, a Guia Nacional de Informação e Apuração do ICMS Substituição Tributária GIA-ST.

116 Artigo 85 - O descumprimento das obrigações principal e acessórias, instituídas pela legislação do Imposto sobre Operações Relativas à Circulação de Mercadorias e sobre Prestação de Serviços de Transporte Interestadual e Intermunicipal e de Comunicação, fica sujeito às seguintes penalidades:

(...)

VII - infrações relativas à apresentação de informação econômico-fiscal e à guia de recolhimento do imposto:

a) falta de entrega de guia de informação - multa de $2 \%$ (dois por cento) do valor das operações de saídas ou das prestações de serviço realizadas no período, nunca inferior ao valor correspondente a 350 (trezentas e cinquenta) UFESPs; entrega até o décimo quinto dia após o transcurso do prazo 
Ora, se consideramos que a norma individual e concreta tirada pelo sujeito passivo do ICMS só ingressa no sistema do direito positivo quando o ente tributante tem conhecimento de sua existência ${ }^{117}$, o "lançamento" do ICMS, considerado o regime periódico de apuração, tem lugar quando chega às mãos da Fazenda Pública a guia de informação de que se cuida no art. 56 da Lei n ${ }^{\circ} 6.374 / 89$.

\subsubsection{O regime de estimativa}

Nada obstante a Lei $n^{\circ} 6.374 / 89$ disponha a respeito de regime de estimativa nos seus arts. 48, inc. II, 50, 51, 52, 53 e 54, não vemos necessidade de tecer considerações sobre a matéria. É que não tem aplicação no Estado de São Paulo desde $1^{\circ}$ de janeiro de 2001, na conformidade do disposto no Comunicado Coordenador da Administração Tributária $\mathrm{n}^{\mathrm{o}} 116$, de 16 de novembro de $2000^{118}$.

\subsubsection{Os regimes especiais de apuração}

Como já se disse, a LC no $87 / 96$ dispôs, no seu art. 26, inc. $\mathrm{I}^{119}$, que facultado à lei estadual estabelecer regime de apuração no qual o confronto de créditos e débitos de ICMS "se faça por mercadoria ou serviço dentro de determinado período", bem assim regime de apuração no qual o dito confronto "se faça por mercadoria ou serviço em cada operação".

regulamentar - multa equivalente ao valor de 70 (setenta) UFESPs; entrega após o décimo quinto dia multa de $1 \%$ (um por cento) do valor das operações de saídas ou das prestações de serviço realizadas no período, nunca inferior ao valor correspondente a 140 (cento e quarenta) UFESPs; não existindo operações de saída ou de prestações de serviço - multa equivalente ao valor de 200 (duzentas) UFESPs na falta de entrega ou de 70 (setenta) UFESPs na entrega após o transcurso do prazo regulamentar; em qualquer caso, as multas serão aplicadas por guia não entregue; (Redação dada à alínea pela Lei 13.918, de 22-12-2009; DOE 23-12-2009)

117 Reportamo-nos ao que escrevemos no tópico "2.3.” deste trabalho.

118 COMUNICADO CAT 116 de 16-11-2000

(D.O.E. de 17-11-2000)

Dispõe sobre a cessação do regime de estimativa a partir de $1^{\circ}$ de janeiro de 2001

O Coordenador da Administração Tributária, considerando o disposto no inciso III do artigo 91 do Regulamento do Imposto sobre Circulação de Mercadorias e sobre Prestações de Serviços, aprovado pelo Decreto 33.118, de 14 de março de 1991, comunica que todos os contribuintes que no dia 31 de dezembro de 2000 se encontrem enquadrados no regime de estimativa ficam, a partir de $1^{\circ}$ de janeiro de 2001, desenquadrados desse regime e deverão, em relação aos fatos geradores que ocorrerem:

1 - até 31 de dezembro de 2000, observar o disposto no artigo 89 do Regulamento do ICMS;

2 - a partir de $1^{\circ}$ de janeiro de 2001, observar o disposto no artigo 84 do Regulamento do ICMS.

119 Vide nota de rodapé $\mathrm{n}^{\circ} 108$. 
Andou mal o Poder Legislativo do Estado de São Paulo ao estabelecer, na Lei $\mathrm{n}^{\circ}$ 6.374/89, que delegava tais poderes ao Executivo. Com efeito, é do parágrafo único do seu art. $47^{120}$ que o regulamento poderá determinar que a apuração e o recolhimento do ICMS se façam de acordo com as hipóteses que, da LC nº 87/96, viemos de abordar.

Andou igualmente mal ao prever, no $\S 3^{\circ}$ do seu art. 49, que o regulamento poderá assentar que o recolhimento do imposto se dê independentemente do resultado da apuração periódica nos casos em que incumbido o destinatário do pagamento do imposto quando da entrada da mercadoria no seu estabelecimento, ou do recebimento de serviço.

De toda sorte, a Lei $\mathrm{n}^{\mathrm{o}}$ 6.374/89 prevê expressamente dois distintos regimes especiais.

O primeiro é aquele de que se cuida no $\S 4^{\circ}$ do seu art. 49: o recolhimento do montante retido quando de operações submetidas a "substituição para a frente" se dará independentemente do resultado da apuração periódica.

O segundo é o previsto no seu art. 55: "Tratando-se de contribuinte não obrigado a manter escrituração fiscal, bem como nos casos expressamente previstos, o montante do imposto a recolher corresponde à diferença entre o imposto devido sobre a operação ou prestação tributada e o cobrado na imediatamente anterior, efetuada com a mesma mercadoria ou serviço.". Aqui, a Lei n 6.374/89 tem o amparo do quanto disposto no art. 26, inc. II, da $\mathrm{LC} \mathrm{n}^{\circ}$ 87/96, regra que concede ao legislador estadual competência para assentar regime de apuração no qual o confronto de créditos e débitos "se faça por mercadoria ou serviço em cada operação".

Examinada a Lei $n^{\circ} 6.374 / 89$, não se encontra nada que permita conhecer quais sejam, considerados esses regimes especiais, os momentos nos quais há o sujeito passivo de proceder ao necessário para a constituição do crédito tributário.

120 Artigo 47 - O valor do imposto a recolher corresponde à diferença, em cada período de apuração, entre o imposto devido sobre as operações ou prestações tributadas e o cobrado relativamente às anteriores.

Parágrafo único - O regulamento poderá determinar:

1 - que a apuração e o recolhimento sejam feitos:

a) por mercadoria ou serviço dentro de determinado período;

b) por mercadoria ou serviço, em função de cada operação ou prestação;

2 - a implantação de outro sistema de recolhimento do imposto, que se mostre mais eficiente para combater a sonegação.

3 - a aplicação de percentual fixo sobre a receita bruta aferida, quando o contribuinte realizar operações com mercadorias ou prestações com serviços tributados por alíquotas internas diferenciadas. (Item acrescentado pela Lei 10.619/00 de 19-07-2000; DOE 20-07-2000) 


\subsection{Os regimes especiais do art. 71}

Estabelece a Lei $\mathrm{n}^{\circ} 6.374 / 89$ no seu art. $71^{121}$, cabeça, que autoridades enumeradas no pertinente regulamento podem determinar, de ofício, ou a pedido do particular, a adoção de regime especial com o propósito de facilitar ou compelir à observância da legislação tributária. Nos seus parágrafos $\S \S 1^{\circ}$ e $2^{\circ}$, limita-se o artigo a dispor sobre hipóteses relacionadas a regime especial de cunho sancionatório.

Não calha examinar tais disposições com profundidade. Voltada a atenção para a matéria nuclear deste trabalho, limitemo-nos a registrar que tais "regimes especiais", sejam os implementados de ofício, sejam os decorrentes de pedidos dos particulares, não têm força bastante para atribuir sujeição passiva por substituição a ninguém, haja vista que sujeição passiva, qualquer que seja, é matéria reservada a lei formal, afirmação esta que não é objeto de controvérsia. O mesmo é de se dizer quanto ao rol de mercadorias constantes dos incs. I, XVI, XVII, XVIII e XIX do art. $8^{\circ}$ da Lei $n^{\circ}$ 6.374/89: se somente em relação às operações relativas à circulação destas mercadorias entendeu o Poder Legislativo de fixar tributação de acordo com o regime de substituição "para trás", falece competência ao Poder Executivo para ampliar o elenco, seja manejando "regimes especiais", seja baixando qualquer outro ato administrativo.

O motivo que nos leva a apresentar essas breves reflexões será dado a conhecer quando examinarmos, mais adiante, os reflexos do emprego desse naipe de "regimes especiais" com o propósito de dispor sobre diferimento.

121 Artigo 71 - Em casos especiais e com o objetivo de facilitar ou de compelir à observância da legislação tributária, as autoridades que o regulamento designar podem determinar, a requerimento do interessado ou de ofício, a adoção de regime especial para o cumprimento das obrigações físcais.

$\S 1^{\circ}$ - O regime especial de ofício, em hipótese de infração contumaz à legislação ou de habitual inadimplência do contribuinte, reconhecida em despacho fundamentado da autoridade administrativa, em cada caso, pode determinar, ainda:

1 - o recolhimento antecipado ou simultâneo do imposto devido, em decorrência de cada operação ou prestação realizada, mediante guia, assegurada a não cumulatividade do imposto;

2 - a prestação de informação relativa ao cumprimento do regime especial de ofício. (Item acrescentado pela Lei 10.619/00, de 19-7-2000; DOE 20-7-2000)

$\S 2^{\circ}$ - Na hipótese prevista no item 1 do parágrafo anterior, admitir-se-á o recolhimento englobado, por destinatário e/ou por períodos. (Parágrafo acrescentado pela Lei 10.619/00, de 19-7-2000; DOE 20-7-2000) 


\subsection{Considerações finais}

Importante reter na memória, do que foi abordado nesse capítulo: examinadas a LC $n^{\circ}$ 87/96 e a Lei $n^{\circ}$ 6.374/89, diagnostica-se que ambas mostram-se silenciosas a respeito do momento no qual é de ser concretizado o "lançamento" do imposto. Deduzimos que, no âmbito do regime periódico de apuração de que se cuida na Lei $\mathrm{n}^{\circ}$ 6.374/89, o "lançamento" se verifica quando a guia de informação versada no seu art. 56 chega às mãos da Fazenda Pública, mas observamos que para tanto a Lei não cuida de fixar data precisa. Enfim, tanto nesse regime quanto nos demais ficou a cargo do RICMS/00 fixar o exato momento no qual o "lançamento" do imposto há de se concretizar. 


\section{AS DISSONANTES MANIFESTAÇÕES ACERCA DO CONCEITO E DA NATUREZA JURÍDICA DO DIFERIMENTO}

A primeira dificuldade encontrada por quem deseje estudar o diferimento no âmbito da tributação incidente sobre a circulação de mercadorias destinadas ao consumo é que a respeito dele não se formulou, até agora, nenhum conceito sólido. Compreende-se, haja vista que, em se tratando de uma construção do Direito Positivo, as disposições a ele pertinentes sofreram mutações no decorrer do tempo - e, mesmo delimitada certa época, o diferimento assume, confrontadas as legislações dos Estados, aspectos distintos.

Pode-se afirmar que, regra geral, as manifestações disponíveis para análise detiveram-se menos em conceituá-lo do que em assentar sua natureza jurídica. Cabe lembrá-las, o que passamos a fazer.

\subsection{O diferimento como espécie de não incidência}

Geraldo AtAliba e ClÉBER GiARDinO, estudando legislação pertinente ao ICM $^{122}$ - texto publicado em 1983 -, concluíram que o diferimento deveria ser entendido como espécie de não incidência. Apontando que, na época, não cabia ao destinatário, quando da "entrada" da mercadoria, proceder ao lançamento do imposto devido em consequência da operação por meio da qual a mercadoria lhe chegara às mãos, registraram que, malgrado o diferimento irradiasse efeitos iguais aos da isenção, o que sucedia é que tal operação mostrava-se "tributariamente irrelevante" "123. O que se passava no diferimento, segundo os AA., é que os fornecedores de mercadoria eram ignorados pela legislação, postos de lado e "como não há relação sem sujeito, e como os sujeitos (para efeito de ICM) não existem, não há na verdade relação tributária" ${ }^{124}$. Reconhecer isto, afirmaram, é reconhecer que não há tributo e, portanto, "não incidência ex vi legis"125. Vale registrar que em estudo anterior, datado de 1982, no qual abordado o diferimento do lançamento previsto na legislação paulista do ICM quanto a operações relativas à circulação de cana-de-açúcar em caule,

122 Os AA. não fazem referência a nenhuma legislação estadual em particular.

123 Cf. Linhas Mestras Constitucionais - O Diferimento. Revista de Direito Tributário, São Paulo, n. 23-24, p. 118-145 (p. 134), jan./jun. 1983.

124 Idem, ibidem.

125 Idem, ibidem. 
nada obstante não tenham empregado a expressão "não incidência", já afirmavam que "sob a perspectiva jurídica, as operações anteriores são irrelevantes"126.

O mesmo entendimento foi esposado por IVES GANDRA DA Silva MARTINS, também em $1983^{127}$. O A. registrou que "a técnica de diferimento não é uma técnica de postergação do lançamento (constituição do crédito tributário), mas é técnica da impossibilidade do aparecimento das obrigações tributárias nas operações anteriores" ${ }^{\text {"28, }}$ daí que "técnica de "não incidência' tributária nas operações anteriores"129.

É o ponto de vista, igualmente, de MARÇAL JuSTEN FiLHO. Em obra de 1986, o A. observou que “a norma que estabelece o 'diferimento' está, em realidade, subtraindo à incidência da norma do ICM uma certa operação relativa à circulação de mercadorias"130. No seu entender, não se daria a ocorrência de "fato imponível porque a conjugação das duas normas impede que uma delas seja aplicável" 131 , findando a "norma do diferimento" por atuar "sobre a hipótese de incidência da norma de ICM, enervando sua incidência"132.

Em estudo publicado em 1993, no qual versada a legislação do ICMS paulista, JURACI Altino DE SOUZA mostrou-se de acordo com o entendimento dos AA. citados logo acima. O A. sustenta que "nas sucessivas saídas alcançadas pelo diferimento não se divisa ... a incidência tributária"133.

\subsection{O diferimento como espécie de isenção}

Clélio ChIESA entende que "a figura do diferimento identifica-se mais com o fenômeno da isenção, pois trata de situações que normalmente seriam tributadas, mas que

126 Cf. Diferimento do ICM - Cana-de-açúcar em caule - Entidade subjetivamente isenta de ICM quanto a mercadorias de sua própria produção - Substituição tributária. Revista de Direito Tributário. São Paulo, n. 50, p. 81-91 (p.84), out./dez. 1989.

127 O A. não faz referência a nenhuma legislação estadual em particular, muito embora o contexto permita ao leitor concluir que se reportava à legislação paulista da época

128 CF. A Técnica de Diferimento da Incidência do ICM - Constitucionalidade do Princípio da Não Cumulatividade Quando de sua Adoção. Revista da Procuradoria Geral do Estado de São Paulo. São Paulo, n. 21, p. 169-197 (p. 194), dez. 1983.

129 Idem, ibidem.

130 Cf. Sujeição Tributária Passiva. Belém: CEJUP, 1986, p. 336. No tocante ao diferimento, o A. não faz referência a nenhuma legislação estadual em particular.

131 Idem, ibidem.

132 Idem, ibidem.

133 Cf. A Técnica do Diferimento na Área do ICMS. Revista da Procuradoria Geral do Estado de São Paulo, São Paulo, n. 39, p. 32-47 (p. 33), junho 1993. O estudo volta-se para a legislação paulista da época. 
por força de outra norma que altera a regra-matriz de incidência, elas deixam de ser alcançadas pela tributação" ${ }^{\text {134 }}$.

Também assim entende Aurélio Pitanga SeiXas Filho. Escreveu o A. que a norma do diferimento, transferindo "para um outro momento a ocorrência do fato gerador, está concedendo uma isenção tributária à pessoa que está alienando (circulando) a mercadoria favorecida com o diferimento" ${ }^{, 135}$.

O mesmo entendimento é professado por Edgard Neves Da Silva e Marcello Martins Motta Filho. Segundo os AA., "o diferimento nada mais é do que a dilação do pagamento do imposto e atinge o aspecto temporal do fato gerador, tendo em vista que a sua ocorrência é postergada no tempo, realizando-se num momento futuro", daí que se confunde com a isenção ${ }^{136}$.

Reportando-se ao CTN, art. 178, MARCOS ANDRÉ VINHAS CATÃo atribui ao diferimento o caráter de isenção condicionada. No entender do A., cuida-se de isenção porque importa "modificação do critério temporal para fins de cumprimento da obrigação tributária (pagamento/extinção do crédito)" ${ }^{137}$ - e condicionada porque se aperfeiçoa tão só quando da ocorrência de evento futuro ${ }^{138}$, sendo certo que, não ocorrido este evento, "recrudesceria a obrigação tributária para todos os sujeitos passivos envolvidos na cadeia, e que foram desobrigados ao recolhimento sob o abrigo do diferimento"139.

\subsection{O diferimento como mescla de moratória e substituição}

Em obra que é de 1972, FERNANDO BROCKSTEDT, referindo-se ao "diferimento da incidência" que constava do Regulamento gaúcho do ICM, registrou o entendimento de

134 Cf. ICMS: Sistema Constitucional Tributário: Algumas Inconstitucionalidades da LC 87/96. São Paulo: LTr, 1997, p. 130. O A. não faz referência a nenhuma legislação estadual em particular.

135 Cf. A Responsabilidade Tributária do Exportador de Produto Industrializado pelo ICMS Diferido da Operação Anterior. Revista Dialética de Direito Tributário, São Paulo, n. 8, p. 39-43 (p. 42), mai. 1996. No texto, o A. não faz referência a nenhuma legislação estadual em particular

136 Cf. Outras Formas Desonerativas. In: MARTINS, Ives Gandra da Silva (Coord.). Curso de Direito Tributário. 11. ed. São Paulo: Saraiva, 2009, p. 299-318 (p. 315). Os AA. não fazem referência a nenhuma legislação estadual em particular.

137 Cf. Regime Jurídico dos Incentivos Fiscais. Rio de Janeiro: Renovar, 2004, p. 83. No texto, o A. referese brevemente aos regulamentos do ICMS dos Estados do Rio de Janeiro e de São Paulo, para apresentar exemplos.

138 Idem, p. 85.

139 Idem, ibidem. 
que se cuidava de "um caso típico de suspensão do crédito tributário, uma típica moratória, compreendida à perfeição no parágrafo único do art. 152 do C.T.N., embora seja, também, uma substituição de responsabilidade, prevista no art. 128 do mesmo Código" ${ }^{\text {"140 }}$.

\subsection{O diferimento como simples dado pré-jurídico}

Alcides Jorge Costa entende que, no âmbito do ICMS, "diferimento é uma palavra que é usada no sentido impróprio". Explica: se o legislador, cogitando de sucessivas operações relativas a circulação de mercadoria, "decide que o imposto vai ser cobrado, não aqui, mas ali, bom ele adiou o início da tributação, ou quando ele diz que vai parar aqui, ou vai continuar, ele suprimiu", o que significa que "de um ponto de vista préjurídico, ele diferiu o pagamento de imposto até tal momento", mas "do ponto de vista jurídico ele não diferiu nada, porque nestas operações nunca nasce uma obrigação tributária sequer, portanto, não há nada que seja diferido" ${ }^{\text {141 }}$.

\subsection{O diferimento e suas relações com a substituição tributária "para trás"}

A grande maioria dos estudiosos que se debruçaram sobre o tema relaciona o diferimento, no âmbito do ICM, ou do ICMS, ao universo da "substituição tributária". Vejamos.

Em parecer datado de 1979, focada a legislação mineira do ICM relacionada a operações com leite fresco, pasteurizado ou não, SACHA CALMON NAVARRO COÊLHO dava o diferimento como "tipo de "sujeição passiva indireta por substituição",142 (g.n.). Registrou que cabia ao adquirente industrial o papel de "sujeito passivo de obrigação tributária alheia"143, sendo "contribuinte originário" o vendedor do leite, gizando que o ““fato gerador' pratica-o o vendedor, mas quem paga o ICM é o adquirente, na condição de

140 Cf. O ICM: Impôsto sobre Operaçães Relativas à Circulação de Mercadorias. Porto Alegre: s. n., 1972, p. 202-203.

141 Cf. Lei Complementar no 87/96. In: Lei Complementar no 87/96 - Palestras proferidas em 1996 no Tribunal de Impostos e Taxas - TIT, São Paulo: IOB, s/d, p. 7-30 (p. 12).

142 Cf. ICM - Convênios Interestaduais para Isenção - Diferimento - Lesão de Direito Individual. Revista de Direito Tributário. São Paulo, n. 7-8, p. 71-83 (p. 79), jan./jul. 1979.

143 Idem, ibidem. 
substituto, por expressa determinação legal" ${ }^{, 144}$. O entendimento foi algo modificado pelo A. mais adiante. Em estudo publicado em 1982, permaneceu firme quanto a se constituir o diferimento "em regra, como praticado na área do ICM" de "tipo de "substituição tributária" $" 146$ (g.n.), mas cabendo ao substituto o pagamento de dívida própria - e não alheia $^{147}$.

José EduARdo SoARes De Melo enquadra o diferimento como tipo de "substituição tributária para trás" "148 ou "regressiva"149. Traz como exemplo as operações com sucata, nas quais "é comum exigir-se o ICMS do industrial que adquire tais mercadorias, ao invés do próprio sucateiro (verdadeiro contribuinte) ${ }^{\text {"150 }}$. Em nenhum dos trabalhos citados o A. se reporta a uma legislação estadual em particular. O entendimento do A. é endossado por ReginA HeLENA COSTA ${ }^{151}$.

Idêntico ponto de vista é o de RoQue Antonio CARrazZa. Segundo o A., "com muita frequência a legislação permite que pequenos produtores e comerciantes de incipiente organização deixem de recolher o ICMS quando vendem certas mercadorias (aparas de papel, sucata, leite, cana-de-açúcar etc.)", atribuindo ao adquirente o encargo de pagar o tributo quando "promove sua revenda (em geral depois de havê-las submetido a processos de industrialização)" o que significa, que "pagará o ICMS devido pela operação mercantil que efetivamente realizou e, também, o referente à operação mercantil anterior, beneficiada pelo diferimento" 152 . Conclui: o diferimento não passa de "modalidade de "substituição tributária (no caso, substituição tributária para trás)"153 (g.n.). O A. registrou os mesmos pensamentos em obra de todo recente, na qual examinado o diferimento do

144 Idem, ibidem.

145 Cf. A Natureza Jurídica do Diferimento na Área do ICM. Revista de Direito Tributário, São Paulo, n. 21/22, p. 5-41. (p. 24), jul./dez. 1982. O A. não faz referência a nenhuma legislação estadual em particular.

146 Idem, ibidem.

147 Idem, ibidem.

148 Cf. Curso de Direito Tributário. 9. ed. São Paulo: Dialética, 2010, p. 280.

149 Cf. ICMS - Base de Cálculo - Descontos, Seguros, Juros, Multas, Correção, Reajustes. Pautas na Substituição Tributária. Importações. Base Reduzida e Estorno de Crédito. In: ROCHA, Valdir de Oliveira (Coord.). Grandes Questões Atuais do Direito Tributário. São Paulo: Dialética, 2006, v. 10, p. 276-301 (p. 292).

150 Idem, ibidem.

151 Cf. Praticabilidade e Justiça Tributária: Exeqüibilidade de Lei Tributária e Direitos do Contribuinte. São Paulo: Malheiros, 2007, p. 268.

152 Cf. ICMS. 14. ed. São Paulo: Malheiros, 2009, p. 408. O A. não faz referência a nenhuma legislação estadual em particular.

153 Idem, ibidem. 
lançamento que constara do ora revogado art. 399 do RICMS/00, relacionado a operações com máquinas e implementos agrícolas ${ }^{154}$.

Heleno TAVEIRA TôRRES segue na mesma linha. Em estudo no qual abordada a legislação paulista do ICMS no concernente a operações com combustíveis, escreveu o A. que o diferimento é "modalidade de simples "substituição tributária para trás",155 (g.n.): implica "responsabilidade tributária transferida por lei nas cadeias plurifásicas, na medida que o fato jurídico tributário já se verificou, formando a obrigação tributária à qual há de se reportar o lançamento tributário que se deve operar na esfera do sujeito passivo da operação subseqüente" $" 156$.

Também FÁtima Fernandes RodRIGUES DE SoUZA entende o diferimento como modalidade de substituição tributária ${ }^{157}$.

Paulo Celso Bergstrom Bonilha, de sua banda, entende que o vocábulo diferimento nem sequer deveria ser empregado na legislação do ICMS, haja vista que se cuida, efetivamente, de "substituição regressiva"158.

YlVES JosÉ DE MIRANDA GUIMARÃES ${ }^{159}$, abordando a legislação paulista do ICM, isto nos idos de 1975, dá o diferimento como caso de substituição tributária.

JOSÉ RoBerTo RoSA observa que o diferimento, no âmbito do ICMS, equivale a "substituição tributária pelas operações antecedentes"160. Segundo o A., "significa

154 Cf. ICMS - Extensão dos benefícios fiscais previstos no Convênio-ICMS n. 52/1991 e no art. 399 do RICMS-SP (redação originária), às operações mercantis com partes e peças destinadas a permitir que sistemas de irrigação e implementos agrícolas funcionem de acordo com as necessidades dos usuários possibilidade jurídica - questões conexas. In: CARVALHO, Antonio Augusto Silva Pereira de; FERNÁNDEZ, German Alejandro San Martín (Coords.). Estudos em Homenagem a José Eduardo Monteiro de Barros - Direito Tributário. São Paulo: MP, 2010, p. 569-592 (p. 579-580).

155 Cf. ICMS e Regimes Especiais de Tributação na Venda de Combustíveis - Diferimento, Substituição e Cassação de Inscrição Estadual nos Casos de Adulteração. In: CAMPILONGO, Paulo Antonio Fernandes (Coord.). ICMS: Aspectos Jurídicos Relevantes. São Paulo: Quartier Latin, 2008, p. 123-187 (p. 148). O estudo dá especial atenção ao diferimento constante da legislação paulista.

156 Idem, ibidem.

157 Cf. A Não-Cumulatividade no Direito Tributário Brasileiro. In: MARTINS, Ives Gandra da Silva (Coord.). O Princípio da Não-Cumulatividade. São Paulo: Editora Revista dos Tribunais, 2004, p. 225264 (p. 255). A A. não faz referência a nenhuma legislação estadual em particular.

158 Cf. Notas sobre as Deformações da Incidência Plurifásica do ICMS. Direito Tributário Atual. São Paulo, n. 23, p. $402-409$ (p. 405), 2009. Malgrado o estudo não se volte especificamente para uma legislação estadual em particular, cuida o A. de fazer comentários a respeito da legislação paulista do ICMS.

159 Cf. ICM Análise e Princípios Estruturais. São Paulo: LTR, 1975, p. 152.

160 Cf. A Substituição Tributária no ICMS e sua Eficácia. In: Congresso Nacional de Estudos Tributários (5: 2008: São Paulo, SP) Direito Tributário Linguagem e Método. São Paulo: Noeses, 2008, p. 467-486 (p. 469). 
'transferência de sujeição passiva', ou transferência da responsabilidade tributária para um contribuinte que participe de uma das subseqüentes etapas da circulação da mercadoria" ${ }^{161}$. Observe-se que, em ambos os trabalhos dos quais extraídas as citações, o A. volta sua atenção notadamente para a legislação paulista do ICMS.

É a mesma ótica de PAUlo ANTONIO FERNANDES CAMPILONGO: o diferimento, na área do ICMS, equivale a "substituição tributária para trás"162.

Integram a corrente que atribui ao diferimento o caráter de "substituição para trás", ainda, Renato Lopes Becho ${ }^{163}$, MARIA Rita FERRAGUT ${ }^{164}$ e AROLdo Gomes DE MATTOS $^{165}$.

Vale citar, ainda, ZELMO DENARI. O A. não atribui ao diferimento a rubrica de tipo, nem de modalidade, nem de espécie de substituição tributária: afirma que é consequência da "substituição regressiva". Escreveu que "a substituição regressiva (...) projeta-se sobre fatos geradores pretéritos, ocorrendo, portanto, suspensão da incidência tributária, e, por via de consequiência, diferimento do tributo" ${ }^{166}$. Reportando-se, para apresentar exemplo, à aquisição de retalhos de papel, ou de metal, o A. afirma que o industrial "recolhe, como substituto, o ICMS devido pelo retalhista (contribuinte substituído)", o que, no plano objetivo, "implica diferimento do imposto", pois "o Fisco recebe o tributo com atraso, ou seja, em estágio mais avançado do ciclo produtivo-distributivo"167. Em nenhum dos trabalhos citados o A. se reporta a uma legislação estadual em particular.

161 Cf. Substituição Tributária no ICMS: Manual Explicativo. 2. ed. Itu (SP): Ottoni, 2009, p. 11.

162 Cf. O ICMS e a Antecipação Parcial do Imposto na Operação Interestadual de Circulação de Mercadorias. In: _ (Coord.). ICMS: Aspectos Jurídicos Relevantes. São Paulo: Quartier Latin, 2008, p. 51-76 (p. 55-56). Na parte do trabalho que tange especificamente ao diferimento, o A. não se reporta a nenhuma legislação estadual em particular.

163 Cf. Sujeição Passiva e Responsabilidade Tributária. São Paulo: Dialética, 2000, p. 136-139. Na sua obra, o A. não se reporta a uma legislação estadual em particular.

164 Cf. Responsabilidade Tributária: Conceitos Fundamentais. In: ; NEDER, Marcos Vinicius (Coords.). Responsabilidade Tributária. São Paulo: Dialética, 2007, p. 9-26 (p. 18); Responsabilidade Tributária e o Código Civil de 2002. São Paulo: Noeses, 2005, p. 64. No seu estudo, a A. não se reporta a uma legislação estadual em particular.

165 Cf. ICMS - Comentários à Legislação Nacional. São Paulo: Dialética, 2006, p. 325.

166 Cf. Sujeitos Ativo e Passivo da Relação Jurídica Tributária. In: MARTINS, Ives Gandra da Silva (Coord.). Curso de Direito Tributário. 11. ed. São Paulo: Saraiva, 2009, p. 171-190 (p. 188).

167 Cf. Curso de Direito Tributário. 9. ed. São Paulo: Atlas, 2008, p. 239-240. 
O STF atribui ao diferimento o caráter de instituto e entende que implica substituição do sujeito passivo da obrigação tributária. É o quanto se depreende da ementas ${ }^{168}$ que, por nós acrescentadas de grifo, têm o seguinte teor:

TRIBUTÁRIO. ICM. DIFERIMENTO. NÃO HÁ COMO CONFUNDIRSE O INSTITUTO DO DIFERIMENTO, PELO QUAL APENAS SE TRANSFERE PARA MOMENTO POSTERIOR O RECOLHIMENTO RELATIVO A IMPOSTO CUJO FATO GERADOR JA OCORREU, COM ISENÇÃO DO TRIBUTO PERTINENTE A ESSA OPERAÇÃO ANTERIOR, NEM COMO O PRINCÍPIO DA NÃO CUMULATIVIDADE. SE A LEI LOCAL ADMITE A UTILIZAÇÃO DO CRÉDITO REFERENTE AO VALOR DO TRIBUTO CUJA SAIDA OCORREU COM O DIFERIMENTO, APENAS POSSIBILITA QUE O VALOR DO TRIBUTO (ICM) QUE DEVERIA SER PAGO QUANDO DA ENTRADA DA MERCADORIA NO ESTABELECIMENTO INDUSTRIAL ENTRE EM SEU CAPITAL DE GIRO, COMO SE ELE TIVESSE SIDO RECOLHIDO, EM OPERAÇÃO FICTA, NÃO SIGNIFICANDO ISSO ISENÇÃO, TANTO E CERTO QUE DEIXOU EXPRESSO QUE HAVERIA O DIFERIMENTO. NÃO SE TRATA DE INTERPRETAÇÃO DE LEI LOCAL, MAS SIM DO INSTITUTO DO DIFERIMENTO FATO QUE IMPLICA NA SUBSTITUIÇÃO DO SUJEITO PASSIVO DA OBRIGAÇÃO TRIBUTARIA. (RE 102354, Relator: Min. ALDIR PASSARINHO, SEGUNDA TURMA, julgado em 23/10/1984, DJ 23-11-1984 PP-19927 EMENT VOL-01359-03 PP-00562 RTJ VOL-0011302 PP-00852).

CONSTITUCIONAL. TRIBUTÁRIO. ICMS. DIFERIMENTO. TRANSFERÊNCIA DE CRÉDITO AO ADQUIRENTE. PRINCÍPIO DA NÃO-CUMULATIVIDADE. IMPOSSIBILIDADE. 1 . O regime de diferimento, ao substituir o sujeito passivo da obrigação tributária, com o adiamento do recolhimento do imposto, em nada ofende o princípio da nãocumulatividade (RE 112.098, DJ 14.02.92, e RE 102.354, DJ 23.11.84). 2. $\mathrm{O}$ princípio da não-cumulatividade do ICMS consiste em impedir que, nas diversas fases da circulação econômica de uma mercadoria, o valor do imposto seja maior que o percentual correspondente à sua alíquota prevista na legislação. $O$ contribuinte deve compensar o tributo pago na entrada da mercadoria com o valor devido por ocasião da saída, incidindo a tributação somente sobre valor adicional ao preço. 3. Na hipótese dos autos, a saída da produção dos agravantes não é tributada pelo ICMS, pois sua incidência é diferida para a próxima etapa do ciclo econômico. Se nada é recolhido na venda da mercadoria, não há que se falar em efeito cumulativo. 4. O atacadista ou industrial, ao comprar a produção dos agravantes, não recolhe o ICMS, portanto não escritura qualquer crédito desse imposto. Se a entrada da mercadoria não é tributada, não há créditos a compensar na saída. 5. Impertinente a invocação do princípio da não-cumulatividade para permitir a transferência dos créditos de ICMS, referente à compra de insumos e

168 Disponíveis em <http://www.stf.jus.br/portal/principal/principal.asp>. Acesso em 15 jun 2010. 
maquinário, para os compradores da produção agrícola, sob o regime de diferimento. 6. Agravo regimental improvido. (RE 325623 AgR, Relatora: Min. Ellen Gracie, Segunda Turma, julgado em 14/03/2006, DJ 07-12-2006 PP-00065 Ement VOL-02259-04 pp-00660 RT v. 96, n. 858, 2007, p. 168175 RDDT n. 138, 2007, p. 217).

No que se refere ao TIT, o diferimento é visto como modalidade de substituição tributária, tal como se pode depreender do quanto vai nas seguintes ementas:

ICMS. OPERAÇÕES COM GADO EM PÉ. REGIME DE SUBSTITUIÇÃO TRIBUTÁRIA COM DIFERIMENTO DO PAGAMENTO DO IMPOSTO. REAL DESTINATÁRIO DIVERSO DAQUELE IDENTIFICADO NOS DOCUMENTOS FISCAIS EMITIDOS PARA ACOBERTAR AS OPERAÇÕES. "QUEBRA DO DIFERIMENTO”.

I - A tributação das operações de circulação de mercadoria nas quais compreendido gado em pé é regrada pelo regime de substituição tributária com pagamento diferido do imposto, mas ocorre a "quebra do diferimento" quando o remetente da mercadoria consigna, em documentos fiscais, destinatário diverso daquele que efetivamente a recebeu.

II - Recurso desprovido.

Processo DRT-11-2556/99 - Recurso Ordinário - Primeira Câmara Efetiva - Rel.: Juiz Luiz Fernando Mussolini Júnior - j. 19/6/2001 - v. u. ${ }^{169}$.

ICMS. OPERAÇÕES COM GADO EM PÉ. REGIME DE SUBSTITUIÇÃO TRIBUTÁRIA COM DIFERIMENTO DO PAGAMENTO DO IMPOSTO. REAL DESTINATÁRIO DIVERSO DAQUELE IDENTIFICADO NOS DOCUMENTOS FISCAIS EMITIDOS PARA ACOBERTAR AS OPERAÇÕES. "QUEBRA DO DIFERIMENTO". A tributação das operações de circulação de mercadoria nas quais compreendido gado em pé é regrada pelo regime de substituição tributária com pagamento diferido do imposto, mas ocorre a "quebra do diferimento" quando o remetente da mercadoria consigna, em documentos fiscais, destinatário diverso daquele que efetivamente a recebeu. RECURSO CONHECIDO. PROVIDO. DECISÃO UNÂNIME.

Processo DRT-09-1187/1993; Recurso Especial, j. 08/03/2007, DOE $29 / 03 / 2007^{170}$.

ICMS. REGIME DE SUBSTITUIÇÃO TRIBUTÁRIA COM DIFERIMENTO DO PAGAMENTO DO ICMS. ENTRADA DE CANADE-AÇUCAR PARA FABRICAÇÃO DE ÁLCOOL DESTINADO AO

169 Cf. Ementário do TIT - 2003. São Paulo: Secretaria da Fazenda do Estado de São Paulo, 2003, p. 181.

170 Disponível em <http://www.fazenda.sp.gov.br/tit/default.shtm>. Acesso em 24 jul 2009. 


\section{COMÉRCIO. EVAPORAÇÃO DO PRODUTO FABRICADO. "INTERRUPÇÃO DO DIFERIMENTO".}

I - A evaporação do álcool fabricado a partir de cana-de-açucar é evento que implica interrupção do diferimento do pagamento do ICMS.

II - Recurso desprovido.

RECURSO CONHECIDO. NEGADO PROVIMENTO. DECISÃO UNÂNIME

Processo DRT-11-1309/1998; Pedido de Revisão; j. 15/02/2007; DOE 03/03/2007 ${ }^{171}$.

A CT-SP filia-se à corrente que atribui ao diferimento o caráter de substituição tributária. Citemos, para dar amparo à afirmação, o que escreveu na Resposta à Consulta $\mathrm{n}^{\circ} 9.750$, de 15 de julho de $1976^{172}$ :

2. Diga-se, desde logo, que nas saídas de mercadorias com diferimento do imposto, este sempre é devido, ficando, porém, seu lançamento e recolhimento transferido para determinado momento, previsto no Regulamento.

3. Note-se que, nestas saídas, o adquirente torna-se o contribuinte substituto do tributo, de imediato beneficiado com o favor fiscal, refletido na diminuição do preço das mercadorias adquiridas, assumindo, evidentemente, a obrigação do pagamento do imposto.

No mesmo sentido é a Resposta à Consulta $\mathrm{n}^{\circ} 11.792$, de 24 de abril de $1978^{173}$, da qual selecionamos o seguinte trecho:

7.4. Com a adoção do diferimento, como já vimos em 6.4., o imposto não é cobrado nas etapas anteriores da circulação. Assim, ao recolher o imposto nas hipóteses descritas nos incisos I a IV do artigo 296 do Regulamento do ICM (redação dada pelo Decreto n. 9.917, de 29.06.77), está a consulente pagando, englobadamente, tanto o imposto que lhe cabe recolher como responsável (ou contribuinte substituto), como o que lhe cabe recolher como contribuinte.

Citemos, ainda, fragmento da Resposta à Consulta $\mathrm{n}^{\mathrm{o}} 12.459$, de 18 de setembro de $1978^{174}$ :

171 Idem. Acesso em 12 set 2009.

172 Cf. LARANJEIRA, Álvaro Reis (Org.) ICM: Respostas da Consultoria Tributária. v. 2. São Paulo: LTr, 1984, p. 19.

173 Idem, p. 164.

174 Idem, p. 192. 
3. A palavra diferimento (que o Código Tributário Nacional não utilizou, mas que aparece no artigo $4^{\circ}$ do Ato Complementar $n^{\circ} 31$, de 28.12.66) indica uma substituição tributária em linha vertical dentro do ciclo de circulação de mercadoria ou, em outras palavras, a transferência da responsabilidade tributária para um dos contribuintes que irá executar uma das etapas futuras da circulação de determinada mercadoria.

\subsection{Nossas ponderações}

O exame do acervo de manifestações que viemos de abordar de forma a mais simples possível é bastante para concluir que acerca do conceito e da natureza jurídica do diferimento não há entendimento uniforme.

Registramos, mais acima, que as disposições legais pertinentes ao diferimento no âmbito dos impostos incidentes sobre a circulação de mercadorias sofreram mutações no decorrer do tempo. Não calha, no bojo deste trabalho, examinar com detença a longa evolução pela qual o diferimento passou no correr do tempo. Parece-nos interessante roborar, todavia, uma outra afirmação que fizemos, qual seja: mesmo delimitada certa época, o diferimento assume, confrontadas as legislações dos Estados, aspectos distintos. Se não, vejamos, limitando-nos ao exame de regulamentos, nos quais a matéria, frente às leis formais que lhes dão suporte, é mais amplamente abordada.

Os dispositivos que, constantes do RICMS/00, interessam ao estudo, dispõem de um aspecto que lhes é comum, o que autoriza a apresentá-los do seguinte modo: nas operações relativas à circulação de tais ou quais mercadorias, o lançamento do imposto não se dará no momento em que o remetente der saída aos bens, mas ficará diferido para momento futuro.

Observa-se, então, que o diploma faz referência a princípio da clareza do tributo. Vale acrescentar que o RICMS/00 não conceitua, expressamente, o que seja princípio da clareza.

Esquadrinhada a legislação de outras Unidades da Federação, o que se encontra é algo semelhante, o que, por óbvio, não implica dizer idêntico. Se não, vejamos. 
No seu art. 666, típico preceito de cunho didático, o RICMS paraense ${ }^{175}$ atribui ao diferimento o caráter de instituto - e registra que, por seu intermédio, "o momento do recolhimento do imposto incidente é postergado para evento futuro indicado em legislação tributária, sendo a responsabilidade do recolhimento do imposto transferida para o contribuinte que promover tal evento" (g. n.). O mesmo se dá no Decreto que regulamenta o ICMS no Estado de Pernambuco ${ }^{176}$ : consta do $\S 1^{\mathrm{o}}$ do seu art. 12 que o diferimento é a situação tributária na qual é transferida "para o adquirente ou tomador, conforme dispuser a legislação tributária específica, a responsabilidade pelo imposto devido em determinada operação ou prestação" e, cumulativamente, adiado para outro momento "o termo inicial do prazo de recolhimento do imposto devido" (g. n.). O termo recolhimento também é empregado pelo RICMS catarinense ${ }^{177}$ : no artigo $1^{\text {o }}$ do Capítulo I do Título I do seu Anexo 3 está escrito que "nas operações abrangidas por diferimento, fica atribuído ao destinatário da mercadoria a responsabilidade pelo recolhimento do imposto na condição de substituto tributário" (g. n.).

Já no RICMS gaúcho ${ }^{178}$ - Livro III, Título I, Capítulo I, art. $1^{\circ}$ - as palavras são outras: "difere-se para a etapa posterior o pagamento do imposto devido nas operações com as mercadorias relacionadas no Apêndice II, Seção I ...” (g. n.). O mesmo vocábulo é utilizado no RICMS capixaba ${ }^{179}$ : segundo seu artigo 10, "o pagamento do imposto fica diferido nas hipóteses e condições previstas no Anexo III” (g. n.). Idem para o RICMS paranaense ${ }^{180}$, cujos artigos 94 e ss. dizem com o diferimento do pagamento do imposto.

O RICMS mineiro ${ }^{181}$ também lança mão de preceito didático: é do seu art. $7^{\circ}$ que "ocorre o diferimento quando o lançamento e o recolhimento do imposto incidente na operação com determinada mercadoria ou sobre a prestação de serviço forem transferidos para operação ou prestação posterior" (g. n.).

175 Regulamento aprovado pelo Decreto $\mathrm{n}^{\circ} 4.676$, de 18 de junho de 2001. Disponível em $<$ http://www.sefa.pa.gov.br>. Acesso em 6 jan. 2010.

176 Decreto $\mathrm{n}^{\circ}$ 14.876, de 12 de março de 1991. Disponível em <http://www.sefaz.pe.gov.br>. Acesso em 6 jan 2010.

177 Regulamento aprovado pelo Decreto $\mathrm{n}^{\mathrm{o}} 2.870$, de 27 de agosto de 2001. Disponível em <http://www.sef.sc.gov.br>. Acesso em 6 jan. 2010.

178 Regulamento aprovado pelo Decreto $\mathrm{n}^{\circ}$ 37.699, de 26 de Agosto de 1997. Disponível em $<$ http://www.sefaz.rs.gov.br>. Acesso em 6 jan. 2010.

179 Regulamento aprovado pelo Decreto $\mathrm{n}^{\mathrm{o}} 1.090-\mathrm{R}$, de 25 de outubro de 2002. Disponível em $<$ http://internet.sefaz.es.gov.br>. Acesso em 6 jan. 2010.

180 Regulamento aprovado pelo Decreto $\mathrm{n}^{\circ} 1.980$, de 21 de dezembro de 2007. Disponível em $<$ http://www.sefanet.pr.gov.br>. Acesso em 5 jan. 2010.

181 Regulamento aprovado pelo Decreto $\mathrm{n}^{\circ}$ 43.080, de 13 de dezembro de 2002. Disponível em $<$ http://www.fazenda.mg.gov.br>. Acesso em 7 jan. 2010. 
Outra ainda é abordagem dada ao diferimento no seio do RICMS maranhense ${ }^{182}$ : o seu art. 12 registra que "são diferidos o lançamento e o pagamento do ICMS nas operações e prestações internas nas condições arroladas no anexo 1.3...” (g. n.). Assim também está no RICMS alagoano ${ }^{183}$, cujo art. 11 dispõe que "o diferimento do ICMS ocorrerá quando o lançamento e o pagamento do tributo ... forem transferidos para o sujeito passivo que efetuar a operação ou prestação posterior" (g. n.).

Visto por meio desses exemplos que (i) a legislação de cada uma dessas Unidades da Federação é semelhante, mas não idêntica, bem assim que (ii) não se recomenda empregar como sinônimos os termos lançamento, pagamento e recolhimento, tudo indica ser cauteloso examinar apartadamente o quanto cada uma delas dispõe acerca de diferimento.

Importa registrar, neste passo, que não se trata, aqui, de desmerecer trabalhos nos quais abordado o diferimento na área do ICM, ou do ICMS, de modo genérico, isto é, desatentos às especificidades a ele atribuídas por cada um dos Entes Tributantes. Muito pelo contrário, a partir deles é que se pode cogitar sobre características comuns e, se calhar, idear um conceito, ou formular uma definição, ou atribuir-lhe determinada natureza jurídica.

Seguro, no entanto: observadas as múltiplas configurações a ele atribuídas pelas distintas legislações estaduais, afigura-se difícil idear um conceito que as abranja a todas, o que implica pouco provável elaborar uma definição digna de ser aprovada - e, por derradeiro, cogitar de atribuir-lhe tal ou qual natureza jurídica.

A respeito do tema, vale lembrar SACha CALmon NAvarro CoÊlho. O A., que de início atribuíra ao diferimento o caráter de tipo de substituição tributária ${ }^{184}$, passou a observar mais adiante que "o nomen diferimento pode designar vários fenômenos encontradiços no âmbito dos impostos plurifásicos e não-cumulativos, tais como, entre outros, a isenção intercorrente, a moratória, a substituição tributária para trás e a sujeição

\footnotetext{
182 Regulamento aprovado pelo Decreto $\mathrm{n}^{\mathrm{o}} 19.714$ de 10 de julho de 2003 Disponível em <http://www.sefaz.ma.gov.br>. Acesso em 8 jan. 2010.

183 Regulamento aprovado pelo Decreto $\mathrm{n}^{\circ}$ 35.245, de 26 de dezembro de 1991. Disponível em <http://www.sefaz.al.gov.br>. Acesso em 10 jan. 2010.

184 Ver tópico “3.5." deste trabalho.
} 
passiva por transferência", sendo certo que sua exata identificação "depende da minuciosa apreciação das circunstâncias em jogo" ${ }^{\text {"185 }}$.

Pensamento do mesmo teor é o de PAUlo De Barros CARVAlho: o vocábulo diferimento pode designar distintos fenômenos - e sua "correta identificação deve ser efetuada em cada caso concreto, mediante exame do diploma normativo pertinente" ${ }^{\text {186 }}$.

Enfim, verificar se o diferimento de que se cuida na legislação paulista do ICMS amolda-se a um dos conceitos de que falam a doutrina, o STF, o TIT e a CT-SP, assim como se lhe veste bem uma das naturezas jurídicas por eles cogitadas, exige, preliminarmente, que se analisem os dispositivos que lhe dizem respeito. Passemos a fazêlo.

185 Cf. Possibilidade de Aproveitamento, pela Geradora, dos Créditos de ICMS pelas Entradas de Insumos e Bens do Ativo Afetados à Produção de Energia Elétrica Vendida com Diferimento. O Caso do Pará. Revista Dialética de Direito Tributário. São Paulo: n. 74. p. 130-143 (p. 138); Teoria Geral do Tributo, da Interpretação e da Exoneração Tributária. 3. ed. São Paulo: Dialética, 2003 (pp. 245-247).

186 Cf. Direito Tributário, Linguagem e Método. 2. ed. São Paulo: Noeses, 2008, p. 656. 


\section{O DIFERIMENTO NO RICMS/00}

Embora já o tenhamos anunciado, vale repetir: os dispositivos que, constantes do RICMS/00, interessam ao estudo, dispõem de um aspecto que lhes é comum, o que autoriza a apresentá-los do seguinte modo: nas operações relativas à circulação de tais ou quais mercadorias, o lançamento do imposto não se dará no momento em que o remetente der saída aos bens, mas ficará diferido para momento futuro ${ }^{187}$. Segundo quer o RICMS/00, portanto, se cuida de princípio da clareza do imposto.

Relembremos, de oura banda, que o termo diferimento não consta da Lei $\mathrm{n}^{\circ}$ 6.374/89 sob nenhuma aparência. O diferimento do lançamento constante da atual legislação paulista do ICMS, portanto, é obra cuja autoria somente o Poder Executivo pode assumir.

Pois bem: sempre atentos à concisão procurada neste trabalho, passemos a examinar o acervo que, constante do RICMS/00, diz mais especificamente com diferimento do lançamento, restringindo-nos (i) às operações relativas à circulação de mercadorias mencionadas no seu art. 260 e no Capítulo IV do Título II do seu Livro II, bem assim (ii) às disposições constantes dos seus arts. 427 a 432.

\subsection{As regras básicas}

Certo número de dispositivos do RICMS/00 veiculam regras básicas no tocante ao diferimento do lançamento. São eles os artigos de números 427 a 431. Passemos a examiná-los.

187 O mesmo é de se dizer acerca do diferimento que constava da legislação paulista do ICM. Nos idos de 1979, Paulo Celso Bergstrom Bonilha registrou tratar-se o diferimento de hipótese de caráter excepcional "em que a lei determina que o lançamento do ICM, devido em uma ou mais de uma operação referentes a determinada mercadoria, fica diferido ou postergado para uma etapa subseqüente do curso da circulação dessa mercadoria.”. Cf. Diferimento e Direito de Crédito do ICM. $L T r$ Suplemento Tributário, n. 156, p.681-683 (p. 681), 1979. Informação do mesmo teor foi veiculada por André Nabarrete Neto em 1980, cf. O Recurso Extraordinário das Decisões que Reconhecem o Direito de Crédito do ICM Diferido. Revista da Procuradoria Geral do Estado de São Paulo, São Paulo, n. 17, p. 257-264 (p. 257-259), dez. 1980. 


\subsubsection{Os arts. 427 e 428}

No seu art. $427^{188}$, cabeça, o RICMS/00 prevê que a "sujeição passiva por substituição com responsabilidade pelo imposto relativo a operações anteriores" se "efetiva nas (...) hipóteses" listadas nos subsequentes incisos - e determina que o lançamento do tributo cabe ao estabelecimento no qual venha a "ocorrer" uma de tais hipóteses. Desdobrados para que se possa discriminar cada um dos eventos excogitados pelo Poder Executivo, os mencionados incisos dizem com:

a) a "saída" de mercadoria com destino a consumidor (inc. I, primeira hipótese);

b) a "saída" de mercadoria com destino a usuário final (inc. I, segunda hipótese);

c) a "saída" de mercadoria com destino a pessoa de direito público nãocontribuinte do ICMS (inc. I, terceira hipótese);

d) a "saída" de mercadoria com destino a pessoa de direito privado nãocontribuinte do ICMS (inc. I, quarta hipótese);

e) a "saída" de mercadoria amparada por não-incidência (inc. II, primeira hipótese);

f) a "saída" de mercadoria amparada por isenção (inc. II, segunda hipótese);

g) qualquer "saída" que redunde na impossibilidade de, mais adiante, se dar sequência ao regime (inc. III, primeira hipótese)

h) qualquer "evento" que redunde na impossibilidade de, mais adiante, se dar sequência ao regime (inc. III, segunda hipótese).

188 Artigo 427 - A sujeição passiva por substituição com responsabilidade pelo imposto relativo a operações anteriores se efetiva nas seguintes hipóteses, devendo o lançamento ser efetuado pelo estabelecimento em que ocorrer (Lei 6.374/89, art. $8^{\circ}$, § 10, na redação da Lei 9.176/95, art. $1^{\circ}$, I):

I - a saída de mercadoria com destino a consumidor ou usuário final ou, ainda, a pessoa de direito público ou privado não-contribuinte;

II - a saída de mercadoria ou prestação de serviço, amparada por não-incidência ou isenção;

III - a saída ou qualquer evento que impossibilitar a ocorrência das operações ou das prestações indicadas neste Livro. 
Vale frisar, desde já: como está escrito na cabeça do artigo, o Poder Executivo, ao engendrá-lo, entendeu-se amparado na Lei $n^{\circ} 6.374 / 89$, art. $8^{\circ}, \S 10$, na redação da Lei $\mathrm{n}^{\mathrm{o}} 9.176 / 95$, art. $1^{\mathrm{o}}$, inc. I.

Pois bem: a interpretação do quanto está na cabeça do art. 427 do RICMS/00 leva a concluir que, nas pertinentes operações, o destinatário da mercadoria passará a desempenhar o papel de "substituto tributário" no exato momento em que venha a se concretizar uma das hipóteses mencionadas mais acima. Até então, isto é, antes do momento no qual concretizada tal ou qual hipótese, não cabe ao destinatário o papel de "substituto". Alguém poderia afirmar que, não concretizada nenhuma das hipóteses, o destinatário da mercadoria jamais teria sobre os seus ombros o dever de, funcionando como "substituto", proceder ao lançamento do imposto referente à operação promovida por quem lha remeteu, daí que, no final das contas, o imposto não seria pago. Sucede que, estando a mercadoria na órbita jurídica do destinatário, não é possível que nenhuma das hipóteses venha a se concretizar. Uma delas necessariamente terá lugar, não importa quando. Necessariamente o destinatário (i) promoverá nova operação, o que estaria abrangido nos incs. I, ou II, ou III, primeira hipótese, ou (ii) não promoverá, o que tem valor igual à expressão "qualquer evento" que consta da segunda hipótese do inc. III do mesmo artigo.

Tendo em mente essas anotações, vê-se que o Poder Executivo agiu com o propósito de cercar com paliçadas inexpugnáveis o crédito tributário. Aconteça o que acontecer com a mercadoria, o destinatário não escapará de, menos tarde, mais tarde, proceder ao quanto necessário para a constituição do crédito tributário relacionado às operações antecedentes.

No seu art. $428^{189}$, o RICMS/00 dispõe sobre suspensão ${ }^{190}$ e diferimento do lançamento do tributo, imputando o dever da lançar ao estabelecimento no qual venha a ter

189 Artigo 428 - A suspensão e o diferimento de que trata este Livro ficam interrompidos, devendo o lançamento do imposto ser efetuado pelo estabelecimento em que ocorrer (Lei 6.374/89, art. $8^{\circ}$, § 10, na redação da Lei ${ }^{\circ} 9.176 / 95$, art. $\left.1^{\circ}, \mathrm{I}\right)$ :

I - a saída da mercadoria com destino a consumidor ou usuário final, inclusive pessoa de direito público ou privado não-contribuinte, ressalvada a hipótese prevista no artigo 319;

II - saída de mercadoria ou prestação de serviço amparadas por não-incidência ou isenção;

III - qualquer outra saída ou evento que impossibilitar o lançamento do imposto no momento expressamente indicado.

190 A suspensão do lançamento de que se trata tem relação com o inc. XVIII do art. $8^{\circ}$ da Lei $n^{\circ}$ 6.374/89. Cuida-se de atribuir ao remetente de mercadoria, aqui funcionando como encomendante de sua industrialização por terceiros, a responsabilidade pelo pagamento do imposto devido em consequência 
lugar qualquer dos eventos que, discriminados nos seus incs. ${ }^{191}$, II e III, não diferem do quanto já apontara nos incs. I, II e III do seu art. 427.

Na concepção do art. 428 do RICMS/00, assim como fez em relação ao seu art. 427, o Poder Executivo buscou o amparo do quanto estabelecido na Lei $\mathrm{n}^{\circ}$ 6.374/89, art. $8^{\circ}, \S 10$, na redação da Lei ${ }^{\circ} 9.176 / 95$, art. $1^{\circ}$, I.

Pois bem: examinados lado a lado os arts. 427 e 428 do RICMS/00, poderia o intérprete findar inclinado a deduzir que o Poder Executivo cogitou de dois diversos $\operatorname{conjuntos}^{192}$, apartando os sujeitos passivos originados do emprego da substituição com responsabilidade pelo imposto relativo a operações antecedentes daqueles a quem atribuído o dever de submeter-se às regras do diferimento do lançamento. Estaria incorreto, pois tanto um quanto outro - os arts. 427 e 428 do RICMS/00 - servem para que se dê aplicação ao art. $8^{\circ}, \S 10$ da Lei $n^{\circ} 6.374 / 89$, na redação da Lei $n^{\circ} 9.176 / 95$, art. $1^{\circ}$, inc. I, o qual, por sua vez, dispõe sobre "sujeição passiva por substituição em relação às operações anteriores", tal como consta expressamente.

Enfim, o art. 428 do RICMS/00 dispõe a respeito do mesmo universo de sujeitos passivos de que se trata no seu art. 427. Certo está que, na redação de cada qual foram empregados vocábulos e expressões diferentes, mas isto não é o bastante para retirar do art. 428 do RICMS/00, no aspecto aqui abordado, seu caráter de pleonasmo, frente ao art. 427.

Poder-se-ia arguir que os verbos (i) "efetivar", constante da cabeça do art. 427 e (ii) “interromper", constante da cabeça do art. 428, implicam atribuir a cada qual dos dispositivos um significado diverso. Assim não parece, uma vez que, (i) cuidando-se ambos - os arts. 427 e 428 do RICMS/00 - de conjuntos de regras propositadas à aplicação

das operações diretamente relacionadas com a industrialização, pagamento este que deverá ser concretizado em momento posterior àquele no qual a mercadoria lhe seja devolvida pelo industrializador. Enfim, uma espécie de substituição tributária sui generis. A suspensão do lançamento tem semelhança com o diferimento do lançamento, mas o que as distingue é que, na primeira, o "lançamento" do tributo cabe a quem de início remete a mercadoria, o encomendante de sua industrialização, ao passo que, no segundo, o "lançamento" caberá a quem funcionar como destinatário. Em outras palavras: na suspensão, o lançamento deve levar em conta momento diverso da saída da mercadoria do encomendante da industrialização, mas é dele mesmo, remetente e encomendante, a tarefa de "lançar" o imposto ao depois de encerrada a industrialização, e não do destinatário e industrializador quando da devolução do produto. Neste trabalho, a matéria não será examinada com mais profundidade, haja vista que não se relaciona de perto com seu tema central.

191 A remissão que, na parte final do inc. I do art. 428 do RICMS/00, se faz ao seu art. 319, diz tão só com matéria referente a suspensão do lançamento.

192 Excluído, vale insistir, o que diz respeito a suspensão do lançamento. 
do vertido na Lei $\mathrm{n}^{\circ}$ 6.374/89, art. $8^{\circ}, \S 10$, na redação da Lei ${ }^{\circ} 9.176 / 95$, art. $1^{\circ}$, I, e (ii) devendo o lançamento ser concretizado nos momentos expressamente fixados nos incisos de cada um desses dispositivos, torna-se necessário reconhecer que, no mesmo momento em que se "efetiva" a "sujeição passiva por substituição" há de se "interromper" o diferimento do lançamento. O emprego dos dois verbos, malgrado distintos, não é bastante para dividir, em dois, o universo dos sujeitos passivos aos quais endereçadas as disposições dos artigos sob exame.

\subsubsection{Os arts. 429, 430 e 431}

Na cabeça do seu art. $429^{193}$, o RICMS/00 prescreve que, regra geral, caberá o pagamento do tributo ao estabelecimento destinatário quando, funcionando na operação subsequente como remetente, estiver esta operação enquadrada como "isenta ou não tributada", vedada a apropriação de crédito de ICMS. Certo está que o dispositivo tem íntima relação com o previsto nos arts. 427 , inc. II e 428, inc. II.

O seu parágrafo único diz com 2 (duas) exceções à regra geral inscrita na cabeça do artigo. No que interessa a este trabalho, registre-se o que fixa o item " 1 ” do mencionado parágrafo: o pagamento é dispensado quando, nada embora se trate de operação "não tributada ou isenta", a legislação admita a "manutenção integral do crédito"194. Aqui é de

193 Artigo 429 - Sendo isenta ou não tributada a saída de mercadoria ou a prestação de serviço subseqüiente promovida pelo estabelecimento destinatário, caberá a este efetuar o pagamento do imposto diferido ou suspenso, sem direito a crédito (Lei 6.374/89, art. 59).

Parágrafo único - Esse pagamento fica dispensado quando se tratar de:

1 - remessa de mercadoria ou prestação de serviço não tributada ou isenta, quando a legislação admitir a manutenção integral do crédito;

2 - saída para outro Estado de energia elétrica ou petróleo, incluídos os lubrificantes ou combustíveis líqüidos ou gasosos dele derivados, destinados a comercialização ou industrialização.

Em caso concreto referente à hipótese, assim manifestou-se a CT-SP:

"ICMS - Operações ao abrigo do diferimento de que trata o artigo 399 do RICMS - Considerações.

Resposta à consulta tributária no 255/2006, de 10 de maio de 2006.

1. A Consulente dedica-se à atividade de plantio e comercialização de cana-de-açúcar, vendendo o produto a uma usina paulista. Informa que 'adquire máquinas e/ou implementos agrícolas de fornecedores localizados no Estado de São Paulo, cujas operações realizam-se ao abrigo do diferimento do ICMS de que trata o artigo 399 do Regulamento do ICMS ...'. Considerando que as saídas internas de cana-de-açúcar de produção paulista estão isentas do ICMS, conforme dispõe o artigo 100 do Anexo I do RICMS (não sendo exigido o estorno do crédito correspondente às entradas), entende que está dispensada do pagamento do ICMS diferido, relativo às máquinas e implementos agrícolas, em virtude do disposto no item 1 do parágrafo único do artigo 429 do mesmo regulamento. Outrossim, tecendo considerações sobre o fato de que o montante do imposto integra sua própria base de cálculo, constituindo o respectivo destaque mera indicação para fins de controle (e que no caso em referência, tal base de cálculo seria o próprio valor da operação) pergunta 'se poderá fazer a recuperação do crédito do imposto integrante da operação, mediante aplicação da alíquota ... sobre o valor da operação, e escriturá- 
se registrar que, caso nenhum tributo tenha sido pago nas operações anteriores àquela na qual o lançamento foi diferido, o preço referente à operação "não tributada ou isenta" não será onerado pelo ICMS. O contrário se dará nos casos nos quais a legislação não permita a "manutenção integral do crédito": malgrado a isenção, ou não incidência, ou imunidade, a mercadoria, ao final da sua circulação, terá seu valor onerado pelo ICMS ${ }^{195}$.

O art. 430 do RICMS/00 ${ }^{196}$ - em cujo texto se faz expressa menção ao art. $8^{\circ}, \S 10$, na redação da Lei $n^{\circ} 9.176 / 95$, art. $1^{\circ}$, I - diz com o pagamento do imposto que, do encargo do destinatário, teve como fonte de origem as operações antecedentes. Segundo está na cabeça do artigo, o tributo deverá ser pago de acordo com as regras dos subsequentes incisos.

É do inc. I que o tributo deverá ser pago pelo destinatário englobadamente com o montante devido pela operação que, subsequente àquela na qual se deu o diferimento do

lo em sua escrita fiscal, nos termos das normas legais pertinentes e, em especial, à luz do princípio constitucional da não-cumulatividade do imposto'.

2. Em resposta, informamos que a Consulente está correta quanto à interpretação do artigo 429 do RICMS: devido ao tratamento tributário das saídas internas de cana-de-açúcar de produção paulista, ora vigente, a Consulente está dispensada do pagamento do ICMS relativo à entrada de máquinas e implementos agrícolas em seu estabelecimento. Não poderá, no entanto creditar-se do imposto relativo a essas mercadorias, exatamente porque o imposto correspondente não foi cobrado nem por este nem por outro Estado, a teor do artigo 59 do RICMS (contrario sensu) e do princípio constitucional da nãocumulatividade do imposto."

Disponível em <http://info.fazenda.sp.gov.br/NXT/gateway.dll?f=templates\&fn=default.htm\&vid=sefaz _respct:vrespct>. Acesso em 19 set 2010.

195 Cuida-se de uma distorção que, malgrado diagnosticada, não cabe examinar neste trabalho.

196 Artigo 430 - A pessoa em cujo estabelecimento se realizar qualquer operação, prestação ou evento, previsto neste Livro como momento do lançamento do imposto diferido ou suspenso, efetuará, na qualidade de responsável, o pagamento correspondente às saídas ou prestações anteriores (Lei 6.374/89, art. $8^{\circ}, \S 10$, na redação da Lei $9.176 / 95$, art. $1^{\circ}$, I, e arts. 59 e $67, \S 1^{\circ}$ ):

I - de uma só vez, englobadamente com o imposto devido pela operação ou prestação tributada que realizar, em função da qual, na qualidade de contribuinte, for devedor por responsabilidade original, sem direito a crédito;

II - nas demais hipóteses, observado o disposto no artigo anterior, no período em que ocorrer a operação, a prestação ou o evento, mediante lançamento no livro Registro de Apuração do ICMS, no quadro "Débito do Imposto - Outros Débitos", com a expressão "Diferimento - Vide Observações", ou na guia de recolhimentos especiais, se for o caso, sem direito a crédito.

III - tratando-se de contribuinte sujeito às normas do Regime Especial Unificado de Arrecadação de Tributos e Contribuições devidos pelas Microempresas e Empresas de Pequeno Porte - "Simples Nacional", de uma só vez, mediante guia de recolhimento especial, até o último dia útil da primeira quinzena do mês subseqüente ao das operações. (Inciso acrescentado pelo artigo $2^{\circ}$ do Decreto 52.104, de 29-08-2007; DOE 30-08-2007)

Parágrafo único - No caso do inciso II, no campo "Observações", o contribuinte identificará, com os dados mínimos necessários, a operação, a prestação ou o evento e demonstrará a apuração do imposto. 
lançamento, vier a promover, vedada a apropriação de crédito de ICMS. Frisemos, então, que a hipotética operação subsequente há de ser tributada, onerada pelo imposto ${ }^{197}$.

O inc. II é dirigido para hipóteses diversas da prevista no inciso anterior. Compreendem (i) operações subsequentes enquadradas como "isentas ou não tributadas" nas quais não admitida a manutenção integral do crédito e (ii) eventos nos quais a mercadoria, ingressada na órbita jurídica do destinatário, não é objeto de nova operação ${ }^{198}$.

Nas hipóteses do inc. II, o pagamento do tributo deverá ter lugar "mediante lançamento no livro Registro de Apuração do ICMS", ou (ii) por meio de recolhimento instrumentado por guia de recolhimentos especiais, em ambos os casos vedada a apropriação de crédito de ICMS.

$\mathrm{O}$ inc. III dispõe a respeito do pagamento quando se tratar de sujeito passivo enquadrado no regime alcunhado de Simples Nacional: o imposto originado das operações nas quais funcionou como destinatário deverá ser pago por meio de recolhimento instrumentado por guia de recolhimentos especiais.

No art. $431^{199}$, o RICMS/00 dispõe que, salvo disposição em contrário, o "imposto diferido" deverá ser pago de imediato quando "se der "a entrega simbólica a destinatário de outro Estado de mercadoria depositada em armazém geral localizado neste Estado".

197 A respeito do "pagamento englobado", escreveu a CT-SP, na Resposta à Consulta no 7.729, de 23 de abril de 1975:

"Conforme se verifica, o lançamento do imposto incidente nas sucessivas saídas, dentro do Estado, dos produtos classificados nas posições referidas no $\S 1^{\circ}$ do art. 286, está diferido para o 'momento em que ocorrer a saída dos produtos fabricados com aquelas matérias-primas'. Em outras palavras, ao recolher o imposto devido pela saída dos produtos fabricados com aquela matéria-prima, estará o contribuinte, evidentemente, recolhendo o ICM incidente nas operações anteriores, que estava diferido.

Porém, isso somente poderá ocorrer quando a mercadoria produzida tiver sua saída onerada pelo ICM.". Cf. LARANJEIRA, Álvaro Reis (Org.). ICM: Respostas da Consultoria Tributária. São Paulo: LTr, 1978, p. 137.

198 A título de exemplo: mercadoria que findar destinada ao uso e consumo do próprio estabelecimento, ou que nele vier a perecer.

199 Artigo 431 - Salvo disposição em contrário, caracterizar-se-á como momento de pagamento do imposto diferido ou suspenso, nos termos deste Livro, a entrega simbólica a destinatário de outro Estado de mercadoria depositada em armazém geral localizado neste Estado (Lei $\mathrm{n}^{\circ} 6.374 / 89$, art. $8^{\circ}$, § 10, na redação da Lei n ${ }^{\circ} 9.176 / 95$, arts. $1^{\circ}$, I, e 59). 


\subsection{Regras específicas: a "entrada" como termo final do diferimento do lançamento}

Dispõe o RICMS, no seu art. $432^{200}$, que, "se houver", prevalece sobre as demais a "regra específica de suspensão, de diferimento ou de substituição tributária".

Pois bem: dentre as múltiplas regras específicas que se pode observar no conjunto das tocantes ao diferimento do lançamento, a certo número delas há de se dar especial relevo, quais sejam aquelas cujo propósito é fixar a "entrada" da mercadoria como seu termo final, como evento que encerra a aplicação do regime.

Como vimos, os arts. 427 e 428 do RICMS/00 referem-se a "saída", ou a "evento" que redunde na impossibilidade de, mais adiante, se dar sequência ao regime de diferimento do lançamento. Sucede, todavia, que o RICMS/00 também prevê hipóteses nas quais a "entrada" da mercadoria no estabelecimento destinatário impõe-lhe o encargo de proceder ao "lançamento" do imposto devido em decorrência da operação promovida por quem lha remeteu. Citemos, dentre elas: (i) a "entrada" em estabelecimento industrial, ainda que para simples curtimento, de couro ou pele, em estado fresco, salmourado ou salgado, tal como disposto no art. 383, inc. III, (ii) a "entrada" em estabelecimento industrial de papel usado ou apara de papel, sucata de metal, caco de vidro, retalho, fragmento ou resíduo de plástico, de borracha ou de tecido, de acordo com o art. 392, inc. III, e (iii) salvo disposição em contrário, a "entrada" resultante de "saída promovida por produtor situado em território paulista com destino a comerciante, industrial, cooperativa ou qualquer outro contribuinte, exceto produtor", na conformidade do art. 260.

Nesses casos, o destinatário deverá proceder de acordo com o disposto no art. 430 do RICMS/00, a respeito do qual já falamos.

Importante registrar, neste passo, que nada embora o art. 432 do RICMS induza a pensar que, no respeitante ao diferimento, haveria múltiplas regras específicas tocantes ao momento no qual há de se concretizar o lançamento, na realidade os possíveis momentos resumem-se àqueles apontados no (i) seu art. 428, isto é, quando da "saída" da mercadoria, ou (ii) quando de sua "entrada", consideradas as hipóteses no seu art. 383, inc. III, no seu art. 392, inc. III e do seu art. 260. Nada mais.

200 Artigo 432 - Se houver regra específica de suspensão, de diferimento ou de substituição tributária em relação a operação, prestação ou evento, prevista na legislação como determinante do lançamento do imposto, prevalecerá aquela regra. 


\subsection{As mercadorias abrangidas}

Dentro do campo que delimitamos para estudar, é extenso o rol das mercadorias que, segundo consta do RICMS/00, são objeto de operações cuja tributação está submetida ao regime de diferimento do lançamento.

Iniciemos pelas versadas no seu art. $260^{201}$ : salvo disposição em contrário todas aquelas cuja "saída" for "promovida por produtor situado em território paulista com destino a comerciante, industrial, cooperativa ou qualquer outro contribuinte, exceto produtor".

Abre-se um parêntese: nem a LC n ${ }^{\circ}$ 87/96 nem a Lei $n^{\circ} 6.374 / 89$ fornecem pistas para que se conheça o que seja "produtor". Cuidou o Poder Executivo de aclarar: estabeleceu, no inc. VI do art. $4^{\circ}$ do RICMS $/ 00^{202}$, que é produtor "a pessoa natural dedicada à atividade agropecuária que realize operações de circulação de mercadorias" - e no $\S 2^{\circ}$ do mesmo artigo registrou que, salvo disposição em contrário, também será tratada como produtor "a pessoa natural que exerça a atividade de extrator, de pescador ou de armador de pesca". A duvidosa legalidade da equiparação não será abordada neste trabalho, por fugir de seu propósito.

As demais dizem com as operações às quais se referem os arts. 328 a 383, 385 a 392, 393-A, 394-A e 400-C a 400-F. O elenco, observada o mais possível a redação constante do diploma: (i) operações relacionadas com cooperativa de estabelecimentos rurais, (ii) operações com algodão em caroço, algodão em pluma ou outro produto resultante do beneficiamento, (iii) operações com café cru, (iv) operações com cana-deaçúcar em caule ou seus derivados, (v) operações com feijão, (vi) operações com mamona, soja e outros produtos, (vii) operações dadas como "primeira saída de produto "in natura", (viii) operações com sementes e outros insumos agropecuários; (ix) operações com coelho

201 Artigo 260 - Salvo disposição em contrário, na saída promovida por produtor situado em território paulista com destino a comerciante, industrial, cooperativa ou qualquer outro contribuinte, exceto produtor, o imposto será arrecadado e pago pelo destinatário deste Estado, quando devidamente indicado na documentação correspondente, no período em que a mercadoria entrar no estabelecimento, observado o disposto no artigo 116 (Lei $6.374 / 89$, art. $8^{\circ}$, I, e $\S 10^{\circ}$, 2, com alteração da Lei 9.176/95, art. $\left.1^{\circ}, \mathrm{I}\right)$.

202 Artigo $4^{\circ}$ - Para efeito de aplicação da legislação do imposto, considera-se (Convênio SINIEF-6/89, art. $17, \S 6^{\circ}$, na redação do Convênio ICMS-125/89, cláusula primeira, I, e Convênio AE-17/72, cláusula primeira, parágrafo único):

VI - produtor, a pessoa natural dedicada à atividade agropecuária que realize operações de circulação de mercadorias. 
e aves, (x) operações com gado em pé e produtos resultantes da matança ${ }^{203}$, (xi) operações com equinos de raça, (xii) operações com leite, (xiii) operações com pescado, (xiv) operações com material reciclável, (xv) operações com produtos têxteis, (xvi) operações com alumínio, (xvii) operações com insumos da indústria de glutamato monossódico ou lisina.

É certo que não apontamos, dentre os distintos gêneros, cada uma das mercadorias. Foi proposital: listá-las uma a uma consumiria páginas e páginas, o que não se mostra conveniente. De toda sorte, parece-nos que o rol, da forma como fizemos constar, é suficiente para dar uma boa ideia de quais sejam as mercadorias compreendidas em cada um dos mencionados gêneros.

Importante destacar que, malgrado expressamente previsto o diferimento do lançamento no tocante a operações com sementes e outros insumos agropecuários nos arts. 355 a 361 do RICMS/00, sua efetiva aplicação não tem lugar no respeitante à maior parte das mercadorias neles listados, uma vez que, em relação a estes, encontra-se "suspensa a disciplina", tal como disposto no art. 17 das Disposições Transitórias do próprio RICMS $/ 00^{204}$.

Anote-se com grande destaque, dada sua inegável relevância: ao discriminar os gêneros de mercadorias cujas operações têm sua tributação submetida ao regime de diferimento do lançamento do imposto, o RICMS/00 se reporta expressamente aos incisos do art. $8^{\circ}$ da Lei no 6.374/89 que dizem respeito a substituição "para trás". A única exceção diz com os equinos de raça aos quais se refere seu art. 388, caso peculiar ao qual dedicaremos, mais adiante, umas tantas ou quantas linhas.

203 Sim, é este o termo que consta do RICMS/00. Melhor seria, no nosso entender, que tivesse empregado o vocábulo "abate", decerto mais apropriado para a espécie.

204 Artigo 17 (DDTT) - Fica suspensa a disciplina do diferimento do lançamento do imposto prevista nos artigos 355 a 361 deste regulamento enquanto vigorar o benefício fiscal de isenção previsto no artigo 41 do Anexo I, exclusivamente em relação aos produtos ali indicados. 


\subsection{Nossas conjecturas acerca do conceito e da natureza jurídica do diferimento do lançamento constante do RICMS/00}

Amparados no conteúdo dos tópicos precedentes, parece-nos que já reunimos força bastante para formular conjecturas acerca do conceito e da natureza jurídica do diferimento do lançamento constante do RICMS/00.

Preliminarmente: malgrado sabedores de que o mais correto seria empregar “constituição do crédito tributário por meio de regra individual e concreta produzida pelo sujeito passivo e dada a conhecer ao ente tributante", para facilitar a exposição adotaremos o termo "lançamento", que foi o empregado tanto pela Lei $\mathrm{n}^{\circ}$ 6.374/89 quanto pelo RICMS/00. O expediente permite evitar que alguém entenda que nos referimos a algo que não está nos citados diplomas legais.

Pois bem: como vimos, os dispositivos que, integrantes do RICMS/00, dizem com diferimento do lançamento, reportam-se aos dispositivos que, na Lei ${ }^{\circ}$ 6.374/89, dizem com a atribuição de sujeição passiva por substituição tocante ao imposto devido pela concretização de precedentes operações relativas à circulação de mercadoria.

Cuidando-se de sujeição passiva por substituição no âmbito de operações relativas à circulação de mercadoria, somente a quem for atribuído o papel de "substituto" cabe proceder ao "lançamento" do imposto. O "substituído" não procede a nenhum "lançamento" do imposto: não lhe cabendo pagar nada à guisa de tributo, seria um notável despropósito excogitar de ocupá-lo com qualquer que fosse "lançamento" tributário, ou de atribuir-lhe a tarefa de proceder ao que fosse necessário para constituir qualquer que fosse crédito tributário. Como era de se esperar, nem a Lei no $6.374 / 89$ nem o RICMS/00 atribuem encargos do naipe ao "substituído". Mais: nada na Lei nº 6.374/89 e nada também no RICMS/00 atribui ao "substituído" a tarefa de proceder ao quanto necessário à constituição de um embrião de crédito tributário que fosse mantido em estado de animação suspensa até que, por obra do "substituto", viesse e se aperfeiçoar, a ganhar vida plena. Examinada a legislação, qualquer cogitação a respeito de algo semelhante a tal hipótese implicaria notável absurdez.

Quando, dada certa operação relativa à circulação de mercadoria, se atribui ao destinatário, funcionando como "substituto", o encargo de proceder ao "lançamento" do imposto no momento em que a mercadoria dá entrada em seu estabelecimento, tal como 
está nos arts. 260, 383, inc. III e 392, inc. III, do RICMS/00, não há falar em diferimento. Visto que a própria legislação determinou que o "lançamento" deve ser concretizado neste momento, isto é, no instante em que "entra" a mercadoria no seu estabelecimento, do ponto de vista jurídico nada foi postergado.

Da mesma sorte, não há falar propriamente em diferimento do lançamento quando a legislação fixa que o imposto devido em decorrência da concretização de tal ou qual operação não deverá ser lançado por quem a promoveu, mas pelo destinatário, isto tão só no instante em que ele mesmo, destinatário, funcionando como remetente, der saída à mercadoria, ou quando, já ingressada a mercadoria na sua órbita jurídica, venha a suceder um evento que a impeça de ser objeto de nova operação.

Em síntese, as regras que, constantes do RICMS/00, dizem com diferimento do lançamento do imposto, (i) não guardam relação com nenhuma espécie de postergação e (ii) o lançamento ao qual se referem não é nada mais do que aquele da incumbência do agente econômico ao qual a Lei $n^{\circ}$ 6.374/89 imputou o papel de sujeito passivo por substituição.

Assim caracterizadas, tais regras mostram-se de todo inúteis. Servem, no máximo, para dar causa a perplexidades. Desnecessário conceituar o que seja o diferimento do lançamento no seio da legislação paulista do ICMS, o que, por sua vez, torna irrelevante indagar qual seja sua natureza jurídica.

Para os que formam nas fileiras segundo as quais a ideação de conceitos e formulação de definições não podem ser deixadas de lado, o máximo que poderíamos registrar é que as disposições tocantes ao diferimento do lançamento enfeixadas no RICMS/00 são prescrições de caráter informativo cuja função é advertir os agentes econômicos de que o "lançamento" do tributo, nas operações relativas à circulação de mercadorias a que se referem, cabe ao destinatário dos bens - e não a quem os remete.

Entendemos, portanto, que o diferimento do lançamento de que se cuida no RICMS/00 não se enquadra em nenhuma das hipóteses que, precedentemente abordadas, foram cogitadas pela doutrina, pelo STF, pelo TIT e pela CT-SP.

Nossas conjecturas, todavia, revelam mais uma vez o acerto de KARL POPPER: apresentada uma solução, revela-se novo problema, o que exige a apresentação de nova 
solução. É que nossas conjecturas não se aplicam ao diferimento do lançamento quando empregado, pelo Poder Executivo, para alcançar desígnios outros que não os permitidos pelo art. $8^{\circ}$ da Lei $n^{\circ} 6.374 / 89$. Em outras palavras, nossas conjecturas não servem para os casos nos quais o diferimento do lançamento não se justifica na substituição tributária "para trás" tal como prevista na Lei $n^{\circ} 6.374 / 89$, não serve para dizer nada a respeito de atos administrativos maculados de ilegalidade, tais como os baixados para, passando ao largo dos limites da Lei $\mathrm{n}^{\circ}$ 6374/89, ampliar o rol de mercadorias em relação às quais possível a aplicação da substituição tributária e, por ricochete, atribuir sujeição passiva por substituição a uns tantos ou quantos agentes econômicos. Como se sabe - e a respeito disso não há controvérsias - sujeição passiva, seja lá de que tipo for, é tema absolutamente reservado a lei formal. Aplicável, às inteiras, o princípio da reserva legal.

Sucede que, ao formular nossas conjecturas, interessaram-nos as hipóteses nas quais a legalidade foi prestigiada. Não as maculam as hipóteses que se caracterizam por contaminadas de ilegalidade, por gravadas de abuso de poder. O conceito destas, se calhar a alguém de ideá-lo, há de incluir, necessariamente, a expressão "ato ilícito", ou outra que se assemelhe. 


\section{A ATRIBUIÇÃO DE SUJEIÇÃO PASSIVA POR SUBSTITUIÇÃo POR MEIO DE DIPLOMAS INFRALEGAIS}

Afirmamos, mais acima, que nossas conjecturas acerca do conceito e da natureza jurídica do diferimento do lançamento constante do RICMS/00 não servem para os casos nos quais o Poder Executivo, passando ao largo da Lei $n^{\circ}$ 6.374/89, entende de ampliar o rol de mercadorias em relação às quais possível a aplicação da substituição tributária e, por ricochete, atribuir sujeição passiva por substituição a uns tantos ou quantos agentes econômicos.

Fixada nossa atenção nos limites dentro dos quais há de ser levada à prática a atuação normativa do Poder Executivo, cabe registrar que, ao tempo da edição do Dec. $n^{\circ}$ 45.490/00, por meio do qual aprovado o RICMS/00, a Constituição Paulista dispunha no seu art. 47, inc. III, que competia privativamente ao Governador do Estado "sancionar, promulgar e fazer publicar as leis, bem como expedir decretos e regulamentos para a sua fiel execução" ${ }^{205}$. Demais disso, a Carta Paulista determinava - e ainda determina -, no mesmo artigo, inc. XVI, ser da competência privativa do Governador "delegar, por decreto, a autoridade do Executivo, funções administrativas que não sejam de sua exclusiva competência" (g. n.).

Some-se que o Poder Legislativo estabeleceu, na Lei no $10.177 / 98$, que Decreto é ato administrativo de competência privativa do Governador do Estado (art. 12, inc. I, al. "a") - e que somente por Decreto serão editados regulamentos (art. 15, cabeça). Atento ao princípio da legalidade, registrou, no inc. I do art. 15 da mesma Lei, que "nenhum regulamento poderá ser editado sem base em lei, nem prever infrações, sanções, deveres ou condicionamentos de direitos nela não estabelecidos”. Mais adiante, no art. 20, inc. I, dispôs que indelegável "a competência para a edição de atos normativos que regulem direitos e deveres dos administrados". Entendeu, ainda, de fixar como ato administrativo de competência comum "a todas as autoridades, até o nível de Diretor de Serviço; às

205 O texto foi alterado por meio da Emenda Constitucional $\mathrm{n}^{\mathrm{o}} 24$, de 23 de janeiro de 2008, passando a constar: "III - sancionar, promulgar e fazer publicar as leis, bem como, no prazo nelas estabelecido, não inferior a trinta nem superior a cento e oitenta dias, expedir decretos e regulamentos para sua fiel execução, ressalvados os casos em que, nesse prazo, houver interposição de ação direta de inconstitucionalidade contra a lei publicada". Na redação que assumiu, o inciso é objeto da Ação Direta de Inconstitucionalidade $\mathrm{n}^{\circ}$ 4.052-9. 
autoridades policiais; aos dirigentes das entidades descentralizadas, bem como, quando estabelecido em norma legal específica, a outras autoridades administrativas, a Portaria" (art. 12, inc, II, al. “a”).

A enumeração foi longa, mas necessária. Vejamos quais sejam os motivos que nos levaram a fazê-la.

\subsection{A atribuição de sujeição passiva por substituição por meio do RICMS/00}

Com fundamento nos dispositivos que, agrupados no art. $8^{\circ}$ da Lei $n^{\circ} 6.374 / 89$, dizem com "sujeitos passivos por substituição" no pertinente a "operações antecedentes", o Governador do Estado, por meio do Dec. no 45.490/00, entendeu de aprovar o RICMS/00, no qual dispostas as regras tocantes ao diferimento do lançamento do imposto.

Como já registramos, de acordo com o art. $8^{\circ}$ da Lei $n^{\circ} 6.374 / 89$ a substituição tributária "para trás" tem a ver com um determinado rol de mercadorias, quais sejam, vale repetir:

a) todas cuja "saída" for "promovida por produtor ou extrator de minério", desde que não funcione como destinatário da mercadoria um outro produtor, ou extrator de minério (incs. I e XIX);

b) "papel usado e apara de papel, sucata de metal, caco de vidro, retalho, fragmento e resíduo de plástico, de borracha ou de tecido" (inc. XVI);

c) "produto agropecuário e seus insumos ou mineral” (inc. XVII);

d) toda aquela remetida para industrialização por conta de terceiro (inc. VIII).

Ora bem, se alargado por meio de regulamento esse rol, os agentes econômicos que se ocuparem de operações relativas à circulação das mercadorias a ele acrescentadas, no papel de destinatários, passarão a desempenhar o papel de "substitutos". Em outras palavras, a eles será atribuída sujeição passiva por meio de diploma infralegal, o que não se admite. 
Sucede que assim ocorre: na sua redação atual, constam do RICMS/00 mercadorias que não se enquadram, por mais que se deseje, no rol de que se cuida no art. $8^{\circ}$ da Lei n 6.374/89. Exemplos que gritam:

a) tecidos, vestimentas das mais variadas e tapeçarias, todos englobados na hipótese do art. 400-C do RICMS/00 $206 \mathrm{e}$

b) ácido clorídrico, amônia anidra e soda cáustica, todos englobados na hipótese do art. 400-F do RICMS/00 207

206 Artigo 400-C - O lançamento do imposto incidente na saída dos produtos classificados nos capítulos 50 a 58 e 60 a 63, exceto os produtos das posições 5001 a 5003, 5101 a 5105, 5201 a 5203, 5301 a 5305, 5505, 5601, 5604, 5607, 5608, 5609, 6305, 6306, 6309 e 6310, todos da Nomenclatura Brasileira de Mercadorias do Sistema Harmonizado - NBM/SH, fica diferido, na proporção de 33,33\% (trinta e três inteiros e trinta e três centésimos por cento) do valor da operação, para o momento em que ocorrer (Lei $n^{\circ} 6.374 / 89$, art. $8^{\circ}$, XXIV, e $\S 10$, na redação da Lei n ${ }^{\circ} 9.176 / 95$, art. $1^{\circ}$, I):

I - sua saída, promovida pelo estabelecimento fabricante:

a) para outro Estado;

b) para o exterior;

c) Revogada pelo artigo $3^{\circ}$ do Decreto 52.104, de 29-08-2007; DOE 30-08-2007.

d) para consumidor final;

II - sua saída do estabelecimento comercial;

III - a saída de outros produtos não indicados expressamente no "caput" nos quais tenham sido empregados os produtos abrangidos pelo diferimento.

207 Artigo 400-F - O lançamento do imposto incidente na saída interna das mercadorias relacionadas no $\S 1^{\circ}$ promovida pelo estabelecimento fabricante com destino a estabelecimento fabricante de glutamato monossódico ou lisina, classificados, respectivamente, nos códigos 2922.42.20 e 2922.41.10 da Nomenclatura Brasileira de Mercadorias - Sistema Harmonizado - NBM/SH, fica diferido para o momento em que ocorrer a saída desses produtos do estabelecimento fabricante (Lei 6.374/89, art. $8^{\circ}$, XXIV e $\S 10$, na redação da Lei $9.176 / 95$, art. $\left.1^{\circ}, \mathrm{I}\right)$.

$\S 1^{\circ}$ - $\mathrm{O}$ disposto neste artigo aplica-se às mercadorias a seguir relacionadas, segundo o código da Nomenclatura Brasileira de Mercadorias - Sistema Harmonizado - NBM/SH:

1 - açúcar, 1701.11.00;

2 - melaço, 1703.10.00;

3 - xarope, 1703.90.00;

4 - aline, 2106.90.90;

5 - farelo de soja, 2304.00.90;

6 - ácido clorídrico, 2806.10.20;

7 - ácido sulfúrico, 2807.00.10;

8 - ácido fosfórico, 2809.20.19;

9 - amônia anidra, 2814.10.00;

10 - soda cáustica, 2815.12.00.

$\S 2^{\circ}$ - O diferimento previsto neste artigo fica condicionado a que:

1 - o estabelecimento remetente e o destinatário:

a) sejam usuários de sistema eletrônico de processamento de dados para emissão e escrituração de documentos fiscais, nos termos de disciplina estabelecida pela Secretaria da Fazenda;

b) estejam regulares com o cumprimento das obrigações acessórias;

2 - o estabelecimento destinatário:

a) esteja credenciado pela Secretaria da Fazenda, conforme disciplina por ela estabelecida;

b) entregue ao remetente declaração de que atende às condições exigidas para o diferimento e de que as mercadorias adquiridas serão destinadas exclusivamente à fabricação de glutamato monossódico ou lisina, classificados, respectivamente, nos códigos 2922.42.20 e 2922.41.10 da Nomenclatura Brasileira de Mercadorias - Sistema Harmonizado - NBM/SH. 
Fácil notar que nas operações relativas à circulação dessas mercadorias os destinatários foram convertidos em "substitutos tributários" por obra e graça do RICMS/00, o que, vale insistir, não se admite.

Não é só. Assinalamos, quando da delimitação do tema deste trabalho: nada embora concentrados no exame da legislação atual, não poderíamos deixar de lado certos dispositivos que, do RICMS/00, foram revogados. Com efeito, não os deixaremos, informando desde já que muitas outras mercadorias estranhas ao rol daquelas relacionadas à substituição tributária "para trás" pela Lei n 6.374/89 - além daquelas logo acima apontadas -, frequentaram o RICMS/00 no intervalo de tempo compreendido de sua edição ao presente, tudo implicando, vale repetir, na atribuição de sujeição passiva por meio de diploma infralegal. Não vamos enumerá-las aqui, mas no tópico seguinte, com isso evitando repetições ociosas e desnecessárias.

\subsection{A atribuição de sujeição passiva por substituição por meio de portarias}

Não é necessário que nos detenhamos em examinar a produção intelectual a respeito dos limites aos quais as portarias devem observância. Basta lembrar que não lhes cabe dispor nada que, na área da tributação, diga com sujeição passiva. Quanto a isso, não há controvérsia. De todo modo, vale lembrar a decisão do STJ cuja ementa tem o seguinte teor:

TRIBUTÁRIO. PIS. DECRETO-LEI 2.052/83. PORTARIA MF No 238/84. ILEGALIDADE. REGIME DE SUBSTITUIÇÃO TRIBUTÁRIA. PREVISÃO LEGAL. AUSÊNCIA.

$\S 3^{\circ}$ - O diferimento previsto neste artigo também se aplica em caso de:

1 - devolução da mercadoria ao remetente;

2 - saída interna das mercadorias relacionadas no $\S 1^{\circ}$, promovida por estabelecimento fabricante de glutamato monossódico ou lisina que as tenha recebido com diferimento, com destino a outro estabelecimento do mesmo titular para fabricação de glutamato monossódico ou lisina.

$\S 4^{\circ}$ - Não satisfeitas as condições estabelecidas neste artigo, não prevalecerá o diferimento, hipótese em que o imposto deverá ser recolhido com multa e demais acréscimos legais devidos a partir do vencimento do prazo em que o imposto deveria ter sido pago, por meio de Guia de Arrecadação Estadual (GARE-ICMS), pelo:

1 - remetente:

a) se o destinatário não estiver credenciado pela Secretaria da Fazenda, conforme previsto na alínea "a" do item 2 do $\S 2^{\circ}$;

b) caso não possua a declaração a que se refere a alínea "b" do item 2 do $\S 2^{\circ}$;

2 - destinatário, em qualquer outra hipótese.

$\S 5^{\circ}$ - A base de cálculo do imposto a ser recolhido na hipótese prevista no item 2 do $\S 4^{\circ}$ será o preço correspondente à ultima entrada da mercadoria. 
1. É ilegal a Portaria MF $n^{\circ} 238 / 84$, pois estabeleceu um regime de substituição tributária não previsto no Decreto-Lei 2.052/83, que lhe servia de fundamento de validade.

2. O Decreto-Lei 2.052/83, no art. 16, autorizou o Ministro de Estado da Fazenda a expedir instruções que viabilizassem a execução do decreto-lei, inclusive referentes "a prazo e forma de recolhimento das contribuições e seus acréscimos" (inciso II).

3. A delegação ao Ministro da Fazenda da prerrogativa de regulamentar a "forma de recolhimento" da contribuição não lhe autorizou a criar, por meio de Portaria, um regime de substituição tributária não previsto em lei. Forma de recolhimento, a que se refere o inciso II do art. 16 do Decreto-Lei $2.052 / 83$, é a obrigação acessória de realizar o pagamento do tributo desta ou daquela maneira, por exemplo, em agência bancária ou diretamente na repartição fiscal, não se confundindo com a fixação do sujeito passivo da obrigação tributária, matéria sob reserva de lei.

4. Recurso especial improvido.

(REsp 838092/SC, Rel. Ministro Castro Meira, Segunda Turma, julgado em 22/05/2007, DJ 08/08/2007 p. 366)

\subsubsection{O caso das operações relativas à circulação de "partes e peças para a fabricação de trator, caminhão e ônibus"}

O lançamento do imposto incidente nas sucessivas operações relativas à circulação de "partes e peças para a fabricação de trator, caminhão e ônibus" era disciplinado pelo RICMS/00 nos seguintes termos:

Artigo 395 - O lançamento do imposto incidente na operação interna promovida pelo estabelecimento fabricante das mercadorias relacionadas no $\S 1^{\circ}$ diretamente a estabelecimento fabricante de trator, caminhão ou ônibus, classificados nas posições 8701, 8702 e 8704 da Nomenclatura Brasileira de Mercadorias - Sistema Harmonizado - NBM/SH vigente em 31 de dezembro de 1996, e de chassis para montagem desses veículos, fica diferido para o momento em que ocorrer a subseqüente saída do destinatário da mesma mercadoria ou de outra resultante de sua industrialização (Lei 6.374/89, art. $8^{\circ}$, XXIV e $\S 10$, redação da Lei $9.176 / 95$, art. $1^{\circ}$, I).

$\S 1^{\circ}$ - Estão abrangidas pelo diferimento exclusivamente as mercadorias a seguir relacionadas, segundo o Código da Nomenclatura Brasileira de Mercadorias - Sistema Harmonizado - NBM/SH vigente em 31 de dezembro de 1996: 
1 - Pneumáticos novos de borracha dos tipos utilizados em ônibus, caminhões e tratores, 4011.20.000 e 4011.91.0200;

2 - Vidros formados e folhas contracoladas de dimensões e formatos que permitam a sua aplicação em automóveis, veículos aéreos, barcos ou outros veículos, 7007.21.0000;

3 - Molas de folhas e suas folhas, 7320.10.0000;

4 - Blocos de cilindros, cabeçotes, cárteres e carcaças, 8409.99.0200;

5 - Virabrequins (árvore de manivela), para motores a explosão ou de combustão interna, 8483.10.0100;

6 - Acumuladores de chumbo, do tipo utilizado para arranque dos motores de pistão, 8507.10.0000;

7 - Cabinas, 8707.90.0102;

8 - Pára-lamas, 8708.29.0100;

9 - Eixo Dianteiro, 8708.50.0100;

10 - Eixo Traseiro, 8708.50.0200;

11 - Vigas e Barras do Eixo Dianteiro, 8708.60.0000;

12 - Rodas, 8708.70.0200;

13 - Radiadores, 8708.91.0000;

14 - Longarina, 8708.99.0600.

$\S 2^{\circ}$ - O diferimento previsto neste artigo aplica-se, também, em relação ao estabelecimento fabricante do trator, caminhão, ônibus ou chassis:

1 - à saída promovida com a mercadoria, com destino a outro estabelecimento do mesmo titular, neste Estado;

2 - ao desembaraço aduaneiro da mercadoria decorrente de importação direta do Exterior.

Cuida-se de mais um exemplo de ampliação do rol de mercadorias fixado pela Lei $n^{\text {o }} 6.374 / 89$ como objeto de operações cuja tributação é submetida ao regime de substituição "para trás" - e consequente atribuição de sujeição passiva por substituição por meio de simples regulamento.

Tal artigo foi revogado por meio do inc. II do artigo $1^{\circ}$ do Decreto $\mathrm{n}^{\circ} 51.520$, de 29 de janeiro de 2007, revogação esta cujos efeitos passariam a irradiar-se a partir de $1^{\circ}$ de fevereiro de 2007. 
Sucede que em 12 de fevereiro de 2007 sobreveio a Portaria CAT n ${ }^{\circ} 15 / 07^{208}$, por meio da qual concedido "regime especial" no qual "restabelecidas" as regras que constavam do revogado dispositivo regulamentar. De início, previu-se que os efeitos da Portaria estender-se-iam de $1^{\circ}$ de fevereiro de 2007 a 30 de junho de 2007. Mais adiante, por intermédio da Portaria CAT n ${ }^{\circ} 64 / 07$, deixou-se de prever prazo final para tanto.

Fácil notar que, no mesmo dia em que deixou de produzir efeitos o revogado art. 395 do RICMS/00, passou a produzir efeitos a Portaria CAT $n^{\circ}$ 15/07, permanecendo,

208 Portaria CAT-15, de 12-2-2007

(DOE 13/02/2007, retificação DOE 14/02/2007)

Concede regime especial às operações internas com partes e peças para fabricação de trator, caminhão ou ônibus

O Coordenador da Administração Tributária, tendo em vista o disposto na no artigo 489 do Regulamento do Imposto sobre Operações Relativas à Circulação de Mercadorias e sobre Prestações de Serviços de Transporte Interestadual e Intermunicipal e de Comunicação - RICMS, aprovado pelo Decreto 45.490, de 30 de novembro de 2000, resolve conceder o seguinte regime especial:

Artigo $1^{\mathrm{o}}$ - Na operação interna promovida pelo estabelecimento fabricante das mercadorias relacionadas no parágrafo único diretamente a estabelecimento fabricante de trator, caminhão ou ônibus, classificados nas posições 8701, 8702 e 8704 da Nomenclatura Brasileira de Mercadorias - Sistema Harmonizado - NBM/SH vigente em 31 de dezembro de 1996, e de chassis para montagem desses veículos, o lançamento do imposto incidente fica diferido para o momento em que ocorrer a subseqüente saída do destinatário da mesma mercadoria ou de outra resultante de sua industrialização.

Parágrafo único - Estão abrangidas pelo diferimento exclusivamente as mercadorias a seguir relacionadas, segundo o Código da Nomenclatura Brasileira de Mercadorias - Sistema Harmonizado NBM/SH vigente em 31 de dezembro de 1996:

1 - Pneumáticos novos de borracha dos tipos utilizados em ônibus, caminhões e tratores, 4011.20.000 e 4011.91.0200;

2 - Vidros formados e folhas contracoladas de dimensões e formatos que permitam a sua aplicação em automóveis, veículos aéreos, barcos ou outros veículos, 7007.21.0000;

3 - Molas de folhas e suas folhas, 7320.10.0000;

4 - Blocos de cilindros, cabeçotes, cárteres e carcaças, 8409.99.0200;

5 - Virabrequins (árvore de manivela), para motores a explosão ou de combustão interna, 8483.10.0100;

6 - Acumuladores de chumbo, do tipo utilizado para arranque dos motores de pistão, 8507.10.0000;

7 - Cabinas, 8707.90.0102;

8 - Pára-lamas, 8708.29.0100;

9 - Eixo Dianteiro, 8708.50.0100;

10 - Eixo Traseiro, 8708.50.0200;

11 - Vigas e Barras do Eixo Dianteiro, 8708.60.0000;

12 - Rodas, 8708.70.0200;

13 - Radiadores, 8708.91.0000;

14 - Longarina, 8708.99.0600.

Artigo $2^{\circ}-\mathrm{O}$ diferimento previsto no artigo $1^{\circ}$ aplica-se, também, em relação ao estabelecimento fabricante do trator, caminhão, ônibus ou chassis:

1 - à saída promovida com a mercadoria, com destino a outro estabelecimento do mesmo titular, neste Estado;

2 - ao desembaraço aduaneiro da mercadoria decorrente de importação direta do Exterior.

Artigo $3^{\circ}$ - Sem prejuízo do disposto nesta portaria, deverão ser observadas também, quando couberem, as disposições dos artigos 428 a 431 do Regulamento do Imposto sobre Operações Relativas à Circulação de Mercadorias e sobre Prestações de Serviços de Transporte Interestadual e Intermunicipal e de Comunicação, aprovado pelo Decreto 45.490, de 30 de novembro de 2000.

Artigo $4^{\circ}$ - Esta portaria entra em vigor na data de sua publicação, produzindo efeitos para fatos geradores ocorridos a partir de $1^{\circ}$ de fevereiro de 2007. (Redação dada ao artigo pela Portaria CAT64/07, de 28-06-2007; DOE 29-06-2007). 
na legislação complementar, a disciplina do diferimento do lançamento para as operações da espécie, ainda que manejado diferente veículo introdutor de normas.

\subsubsection{O caso das operações relativas à circulação de "bebidas destinadas a insumos de outras bebidas"}

O lançamento do imposto incidente nas sucessivas operações relativas à circulação de "bebidas destinadas a insumos de outras bebidas" era disciplinado pelo RICMS/00 nos seguintes termos:

Artigo 397 - O lançamento do imposto incidente na saída de bebidas alcoólicas e demais produtos, classificados nas posições 2204, 2205, 2206 e 2208 da Nomenclatura Brasileira de Mercadorias - Sistema Harmonizado $\mathrm{NBM} / \mathrm{SH}$, acondicionados em recipientes de capacidade superior ao limite máximo permitido para venda a varejo, com destino a estabelecimento industrial que os utilize como insumo na fabricação de bebidas, fica diferido para o momento em que ocorrerem as saídas dos produtos resultantes da sua industrialização, acondicionados em recipientes de capacidade permitida para venda a varejo (Lei 6.374/89, art. $8^{\circ}$, XXIV, e $\S 10$, na redação da Lei 9.176/95, art. $\left.1^{\circ}, \mathrm{I}\right)$.

Parágrafo único - O diferimento previsto neste artigo:

1 - abrange o lançamento do imposto incidente na saída de cana-de-açúcar em caule de produção paulista utilizada na fabricação de aguardente;

2 - estende-se, nas condições do "caput", à remessa efetuada por estabelecimento industrial cooperado à cooperativa de que faça parte ou entre estabelecimentos de cooperativas.

Mais um caso de ampliação do rol de mercadorias fixado pela Lei $n^{\circ}$ 6.374/89 como objeto de operações cuja tributação é submetida ao regime de substituição "para trás" - e consequente atribuição de sujeição passiva por substituição por meio de simples regulamento.

$\mathrm{O}$ artigo foi revogado por meio do inc. II do artigo $1^{\circ}$ do Decreto $\mathrm{n}^{\circ} 51.520$, de 29 de janeiro de 2007, revogação esta cujos efeitos passariam a irradiar-se a partir de $1^{\circ}$ de fevereiro de 2007. 
Ocorre que em 12 de fevereiro de 2007 veio à luz a Portaria CAT n ${ }^{\circ} 10 / 07^{209}$, isto para conceder "regime especial" no qual "restabelecidas" as regras que constavam do revogado art. 397 do RICMS/00. De início, previu-se que a Portaria produziria efeitos de $1^{\circ}$ de fevereiro de 2007 a 30 de junho de 2007. Mais adiante, por intermédio da Portaria

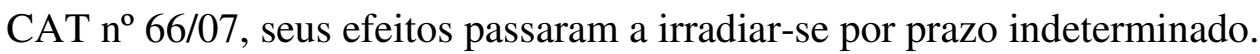

Aqui também: no mesmo dia em que deixou de produzir efeitos o revogado art. 397 do RICMS/00, passou a produzir efeitos a Portaria CAT no 10/07, permanecendo, na legislação complementar, a disciplina do diferimento do lançamento para as operações da espécie.

\subsubsection{O caso das operações relativas à circulação de "insumos e produtos acabados da indústria de processamento eletrônico de dados"}

O mesmo expediente descrito nos casos precedentes foi empregado no tocante a operações relativas à circulação de "insumos e produtos acabados da indústria de processamento eletrônico de dados". Constava do RICMS/00:

209 Portaria CAT-10, de 12-2-2007

(DOE 13-02-2007; Retificação DOE 15-02-2007)

Concede regime especial às saídas de bebidas destinadas a insumos de outras bebidas

O Coordenador da Administração Tributária, tendo em vista o disposto na no artigo 489 do Regulamento do Imposto sobre Operações Relativas à Circulação de Mercadorias e sobre Prestações de Serviços de Transporte Interestadual e Intermunicipal e de Comunicação - RICMS, aprovado pelo Decreto 45.490, de 30 de novembro de 2000, resolve conceder o seguinte regime especial:

Artigo $1^{\circ}$ - Na saída de bebidas alcoólicas e demais produtos, classificados nas posições 2204, 2205, 2206 e 2208 da Nomenclatura Brasileira de Mercadorias - Sistema Harmonizado - NBM/SH, acondicionados em recipientes de capacidade superior ao limite máximo permitido para venda a varejo, com destino a estabelecimento industrial que os utilize como insumo na fabricação de bebidas, $o$ lançamento do imposto incidente fica diferido para o momento em que ocorrerem as saídas dos produtos resultantes da sua industrialização, acondicionados em recipientes de capacidade permitida para venda a varejo.

Parágrafo único - O diferimento previsto neste artigo:

1 - abrange o lançamento do imposto incidente na saída de cana-de-açúcar em caule de produção paulista utilizada na fabricação de aguardente;

2 - estende-se, nas condições do "caput", à remessa efetuada por estabelecimento industrial cooperado à cooperativa de que faça parte ou entre estabelecimentos de cooperativas.

Artigo $2^{\circ}$ - Sem prejuízo do disposto nesta portaria, deverão ser observadas também, quando couberem, as disposições dos artigos 428 a 431 do Regulamento do Imposto sobre Operações Relativas à Circulação de Mercadorias e sobre Prestações de Serviços de Transporte Interestadual e Intermunicipal e de Comunicação, aprovado pelo Decreto 45.490, de 30 de novembro de 2000.

Artigo $3^{\circ}$ - Esta portaria entra em vigor na data de sua publicação, produzindo efeitos para fatos geradores ocorridos a partir de $1^{\circ}$ de fevereiro de 2007. (Redação dada ao artigo pela Portaria CAT66/07, de 28-06-2007; DOE 29-06-2007). 
Artigo 396 - O lançamento do imposto incidente na saída interna promovida pelo estabelecimento fabricante de partes, peças, componentes, matériasprimas e materiais de embalagem com destino a estabelecimento fabricante da indústria de processamento eletrônico de dados abrangido pelo artigo $4^{\circ}$ da Lei federal $\mathrm{n}^{\circ} 8.248$, de 23 de outubro de 1991, para serem utilizados na fabricação de produto da referida indústria, fica diferido para o momento em que ocorrer a saída:

I - da mercadoria resultante de sua industrialização;

II - dos insumos mencionados neste artigo para assistência técnica.

$\S 1^{\circ}$ - O diferimento previsto neste artigo fica condicionado a que:

1 - o estabelecimento remetente e o destinatário, nos termos de disciplina estabelecida pela Secretaria da Fazenda:

a) sejam usuários de sistema eletrônico de processamento de dados para emissão e escrituração de documentos fiscais;

b) estejam regulares com o cumprimento das obrigações acessórias;

2 - o estabelecimento destinatário:

a) esteja credenciado pela Secretaria da Fazenda, conforme disciplina por ela estabelecida;

b) entregue ao remetente declaração de que atende às condições exigidas para o diferimento e de que as mercadorias adquiridas serão destinadas exclusivamente à fabricação de produto beneficiado nos termos do artigo $4^{\circ}$ da Lei federal n 8.248 , de 23 de outubro de 1991.

$\S 2^{\circ}$ - A Secretaria da Fazenda publicará lista contendo os dados cadastrais dos estabelecimentos que estejam abrangidos pelo artigo $4^{\circ}$ da Lei federal $\mathrm{n}^{\circ}$ 8.248, de 23 de outubro de 1991, com base:

1 - em informações recebidas de entidade representativa da indústria de produtos de processamento eletrônico de dados com abrangência em todo território nacional;

2 - no credenciamento de que trata a alínea "a" do item 2 do $\S 1^{\circ}$.

$\S 3^{\circ}$ - O diferimento previsto neste artigo também se aplica em caso de:

1 - devolução da mercadoria ao remetente;

2 - saída interna dos insumos mencionados neste artigo e da mercadoria resultante de sua industrialização, promovida pelo estabelecimento fabricante de produtos de processamento eletrônico de dados com destino a outro estabelecimento, também fabricante de produto beneficiado pela Lei federal $n^{\circ} 8.248$, de 23 de outubro de 1991, credenciado nos termos da alínea "a" do item 2 do $\S 1^{\circ}$.

$\S 4^{\circ}$ - Não satisfeitas as condições estabelecidas neste artigo, não prevalecerá o diferimento, hipótese em que o imposto deverá ser recolhido com multa e demais acréscimos legais devidos a partir do venci mento do prazo em que o imposto deveria ter sido pago, por meio de Guia de Arrecadação Estadual (GARE-ICMS), pelo:

1 - remetente: 
a) se o destinatário não constar na lista a que se refere o $\S 2^{\circ}$;

b) caso não possua a declaração a que se refere a alínea "b" do item 2 do $\S 1^{\circ}$;

2 - destinatário, em qualquer outra hipótese.

$\S 5^{\circ}$ - A base de cálculo do imposto a ser recolhido na hipótese prevista no item 2 do $\S 4^{\circ}$ será o preço correspondente à ultima entrada da mercadoria.

Um outro caso de ampliação do rol de mercadorias fixado pela Lei ${ }^{\circ}$ 6.374/89 como objeto de operações cuja tributação é submetida ao regime de substituição "para trás" - e consequente atribuição de sujeição passiva por substituição por meio de simples regulamento.

Aí mais um dos dispositivos do RICMS/00 revogados pelo inc. II do artigo $1^{\circ}$ do Decreto $\mathrm{n}^{\mathrm{o}}$ 51.520, de 29 de janeiro de 2007, revogação esta cujos efeitos passariam a irradiar-se a partir de $1^{\circ}$ de fevereiro de 2007. Na sequência, a "reanimação", agora pela Portaria CAT $n^{\circ} 14 / 07^{210}$, de início projetada para surtir efeitos de $1^{\circ}$ de fevereiro a 30 de

210 Portaria CAT-14, de 12-2-2007

(DOE 13/02/2007, Refificação DOE 14/02/2007)

Concede regime especial às saídas internas de insumos e produtos acabados da indústria de processamento eletrônico de dados

O Coordenador da Administração Tributária, tendo em vista o disposto na no artigo 489 do Regulamento do Imposto sobre Operações Relativas à Circulação de Mercadorias e sobre Prestações de Serviços de Transporte Interestadual e Intermunicipal e de Comunicação - RICMS, aprovado pelo Decreto 45.490, de 30 de novembro de 2000, resolve conceder o seguinte regime especial:

Artigo $1^{\circ}$ - Na saída interna promovida pelo estabelecimento fabricante de partes, peças, componentes, matérias-primas e materiais de embalagem com destino a estabelecimento fabricante da indústria de processamento eletrônico de dados abrangido pelo artigo $4^{\circ}$ da Lei federal 8.248, de 23 de outubro de 1991, para serem utilizados na fabricação de produto da referida indústria, o lançamento do imposto incidente fica diferido para o momento em que ocorrer a saída:

I - da mercadoria resultante de sua industrialização;

II - dos insumos mencionados neste artigo para assistência técnica.

$\S 1^{\circ}$ - O diferimento previsto neste artigo fica condicionado a que:

1 - o estabelecimento remetente e o destinatário, nos termos da Portaria CAT-53/06, de 8 de agosto de 2006:

a) sejam usuários de sistema eletrônico de processamento de dados para emissão e escrituração de documentos fiscais;

b) estejam regulares com o cumprimento das obrigações acessórias;

2 - o estabelecimento destinatário:

a) esteja credenciado pela Secretaria da Fazenda, conforme a Portaria CAT-53/06, de 8 de agosto de 2006 ;

b) entregue ao remetente declaração de que atende às condições exigidas para o diferimento e de que as mercadorias adquiridas serão destinadas exclusivamente à fabricação de produto beneficiado nos termos do artigo $4^{\circ}$ da Lei federal $n^{\circ} 8.248$, de 23 de outubro de 1991.

$\S 2^{\circ}$ - A Secretaria da Fazenda publicará lista contendo os dados cadastrais dos estabelecimentos que estejam abrangidos pelo artigo $4^{\circ}$ da Lei federal 8.248, de 23 de outubro de 1991, com base:

1 - em informações recebidas de entidade representativa da indústria de produtos de processamento eletrônico de dados com abrangência em todo território nacional;

2 - no credenciamento de que trata a alínea "a" do item 2 do $\S 1^{\circ}$.

$\S 3^{\circ}$ - O diferimento previsto neste artigo também se aplica em caso de: 
junho de 2007, mas cujo termo final passou a indeterminado, força da alteração introduzida pela Portaria CAT n ${ }^{\circ}$ 63/07.

\subsubsection{Outros casos do mesmo gênero}

O rol constante dos precedentes tópicos já vai longo - e a transcrição dos dispositivos do RICMS/00 revogados e das Portarias "revigoradoras" ocupou espaço maior do que convinha. Recomendável, portanto, que os demais casos do gênero sejam mencionados de forma o mais possível sucinta - e evitada a transcrição dos dispositivos concernentes. Ei-los aí, numa síntese apertada:

a) O art. 398 do RICMS/00 dizia com diferimento do lançamento no tocante à "primeira saída" de "carretéis ou bobinas para cabos, caixas, caixotes, engradados, barricas e embalagens semelhantes, paletes simples, paletescaixas e outros estrados para carga, classificados nos códigos 4415.10 .00 e 4415.20.00 da Nomenclatura Brasileira de Mercadorias - Sistema Harmonizado - NBM/SH, todos de madeira ou fibra de madeira, utilizados no manuseio, acondicionamento, transporte ou armazenagem de mercadorias". O dispositivo foi revogado pelo inciso II do artigo $1^{\circ}$ do Decreto $\mathrm{n}^{\circ}$ 51.520/07, a partir de $1^{\circ}$ de fevereiro de 2007. Passo seguinte, concedeu-se o "regime especial" que, veiculado pela Portaria CAT

1 - devolução da mercadoria ao remetente;

2 - saída interna dos insumos mencionados neste artigo e da mercadoria resultante de sua industrialização, promovida pelo estabelecimento fabricante de produtos de processamento eletrônico de dados com destino a outro estabelecimento, também fabricante de produto beneficiado pela Lei federal $\mathrm{n}^{\circ} 8.248$, de 23 de outubro de 1991, credenciado nos termos da alínea "a" do item 2 do $\S 1^{\circ}$.

$\S 4^{\circ}$ - Não satisfeitas as condições estabelecidas neste artigo, não prevalecerá o diferimento, hipótese em que o imposto deverá ser recolhido com multa e demais acréscimos legais devidos a partir do venci mento do prazo em que o imposto deveria ter sido pago, por meio de Guia de Arrecadação Estadual (GARE-ICMS), pelo:

1 - remetente:

a) se o destinatário não constar na lista a que se refere o $\S 2^{\circ}$;

b) caso não possua a declaração a que se refere a alínea "b" do item 2 do $\S 1^{\circ}$;

2 - destinatário, em qualquer outra hipótese.

(omissis)

Artigo $2^{\circ}$ - Sem prejuízo do disposto nesta portaria, deverão ser observadas também, quando couberem, as disposições dos artigos 428 a 431 do Regulamento do Imposto sobre Operações Relativas à Circulação de Mercadorias e sobre Prestações de Serviços de Transporte Interestadual e Intermunicipal e de Comunicação, aprovado pelo Decreto 45.490, de 30 de novembro de 2000.

Artigo $3^{\circ}$ - Esta portaria entra em vigor na data de sua publicação, produzindo efeitos para fatos geradores ocorridos a partir de $1^{\circ}$ de fevereiro de 2007. (Redação dada ao artigo pela Portaria CAT63/07, de 28-06-2007; DOE 29-06-2007) 
$n^{\circ} 13 / 07$, "revigorou" as regras, isto a partir de $1^{\circ}$ de fevereiro de 2007. Força da alteração introduzida pela Portaria CAT $n^{\circ}$ 62/07, o prazo de vigência da Portaria CAT no 13/07 é indeterminado.

b) $\mathrm{O}$ art. 400 do RICMS/00 dizia com diferimento do lançamento no tocante às "sucessivas saídas de internas de palha (ou lã de ferro ou aço, classificadas no código 7323.10.00 da Nomenclatura Brasileira de Mercadorias - Sistema Harmonizado - NBM/SH". O dispositivo foi revogado pelo inciso II do artigo $1^{\circ}$ do Decreto $\mathrm{n}^{\circ} 51.520 / 07$, a partir de $1^{\text {o }}$ de fevereiro de 2007. Logo adiante, concedeu-se o "regime especial" que, veiculado pela Portaria CAT n ${ }^{\circ} 12 / 07$, "reanimou" as regras, isto a partir de $1^{\circ}$ de fevereiro de 2007. Em decorrência da alteração que lhe impôs a Portaria CAT no 61/07, o prazo de vigência da Portaria CAT $\mathrm{n}^{\circ} 12 / 07$ é indeterminado.

\subsection{O Decreto $n^{0} 51.608 / 07$}

O lançamento do imposto incidente nas sucessivas operações relativas à circulação de "máquina ou implemento agrícola" era disciplinado pelo RICMS/00 nos seguintes termos:

Artigo 399 - O lançamento do imposto incidente nas sucessivas saídas internas de máquina ou implemento agrícola fica diferido para o momento em que ocorrer a saída, do estabelecimento rural, dos produtos resultantes sujeitos ao imposto (Lei 6.374/89, art. $8^{\circ}$, XXIV, § 10, na redação da Lei 9.176/95, art. $\left.1^{\mathrm{o}}, \mathrm{I}\right)$.

$\S 1^{\circ}$ - O pagamento do imposto diferido será efetuado nos termos do artigo 430, ressalvada a aplicação do disposto no artigo 432. (Redação dada ao $\S 1^{\circ}$ pelo inciso II do art. $1^{\circ}$ do Decreto 47.923 de 03-07-2003; DOE 04-072003; efeitos a partir de 04-07-2003)

$\S 1^{\circ}$ - Relativamente ao pagamento do imposto diferido:

1 - tratando-se de estabelecimento rural de produtor, será efetuado mediante guia de recolhimentos especiais, deduzindo-se na própria guia o valor do crédito correspondente à entrada;

2 - em relação aos demais estabelecimentos rurais, far-se-á nos termos do artigo 116.

$\S 2^{\circ}$ - As máquinas e os implementos agrícolas a que se refere este artigo são os discriminados na relação prevista no inciso V do artigo 54. 
Temos aqui mais um exemplo de ampliação do rol de mercadorias fixado pela Lei n $6.374 / 89$ como objeto de operações cuja tributação é submetida ao regime de substituição "para trás" - e consequente atribuição de sujeição passiva por substituição por meio de simples regulamento.

O dispositivo foi revogado por força do contido no inciso II do artigo $1^{\circ}$ do Decreto $\mathrm{n}^{\circ} 51.520$, de 29 de janeiro de 2007, revogação esta irradiadora de efeitos a partir de $1^{\circ}$ de fevereiro de 2007. Acontece que o dispositivo foi "reanimado" pelo Decreto $\mathrm{n}^{\circ} 51.608$, de 26 de fevereiro de $2007^{211}$, cujos efeitos passaram a irradiar-se a partir de $1^{\circ}$ de fevereiro de 2007.

Trata-se de caso inusitado, sem sombra de dúvida, ainda mais porque, nada embora o disposto no Decreto $\mathrm{n}^{\circ}$ 51.608/07 diga com regras propositadas à execução da Lei $\mathrm{n}^{\circ} 6.374 / 89$, o quanto veicula não foi transposto para o RICMS/00. Em outras palavras, o Decreto $n^{\circ}$ 51.608/07 não foi empregado para introduzir alterações no RICMS/00; ambos coexistem, apartados um do outro.

211 DECRETO No 51.608, DE 26 DE FEVEREIRO DE 2007

(DOE de 27-02-2007)

Implementa sujeição passiva por substituição na sistemática de lançamento do Imposto sobre Operações Relativas à Circulação de Mercadorias e sobre Prestações de Serviços de Transporte Interestadual e Intermunicipal e de Comunicação - ICMS incidente nas saídas internas de máquinas ou implementos agrícolas

JOSÉ SERRA, Governador do Estado de São Paulo, no uso de suas atribuições legais e tendo em vista o disposto no artigo $8^{\circ}$, XVII e $\S 10$, da Lei $n^{\circ} 6.374$, de $1^{\circ}$ de março de 1989 :

Decreta:

Artigo $1^{\circ}$ - Nas sucessivas saídas internas de máquina ou implemento agrícola, o lançamento do ICMS incidente fica diferido para o momento em que ocorrer a saída, do estabelecimento rural, dos produtos resultantes sujeitos ao imposto.

$\S 1^{\circ}$ - O pagamento do imposto diferido será efetuado nos termos do artigo 430 do Regulamento do Imposto sobre Operações Relativas à Circulação de Mercadorias e sobre Prestações de Serviços de Transporte Interestadual e Intermunicipal e de Comunicação, aprovado pelo Decreto $n^{\circ} 45.490$, de 30 de novembro de 2000, ressalvada a aplicação do disposto no artigo 432 desse mesmo Regulamento.

$\S 2^{\circ}$ - As máquinas e os implementos agrícolas a que se refere este artigo são os discriminados na relação prevista no inciso V do artigo 54 do referido Regulamento do ICMS.

Artigo $2^{\circ}$ - Este decreto entra em vigor na data de sua publicação, produzindo efeitos para fatos geradores que ocorrerem a partir de $1^{\circ}$ de fevereiro de 2007.

Palácio dos Bandeirantes, 26 de fevereiro de 2007 


\subsection{Nossas conjecturas}

Tendo em conta o registrado nos tópicos precedentes, entendemos de fazer as conjecturas que seguem.

No tocante à feição atual do RICMS/00: é ilegal a aplicação do diferimento do lançamento do imposto no bojo das operações que dizem respeito a tecidos, vestimentas das mais variadas e tapeçarias, todos englobados na hipótese do art. 400-C do RICMS/00. Ilegal, do mesmo modo, sua aplicação no seio das operações que dizem respeito a ácido clorídrico, amônia anidra e soda cáustica, todos englobados na hipótese do art. 400-F do RICMS/00.

Consideradas as demais feições que o RICMS/00 assumiu no curso do tempo, mostrou-se gravada de ilegalidade a aplicação do diferimento do imposto no tocante a operações versadas nos seus revogados arts. 395, 396, 397, 398, 399 e 400.

No tocante às Portarias que, na falta de melhor expressão, vieram a "ressuscitar" a aplicação do diferimento do lançamento no que se refere às operações relativas à circulação das mercadorias anteriormente apontadas nos arts. 395, 396, 397, 398 e 400 do RICMS/00, também as entendemos ilegais.

Em primeiro lugar, porque ato administrativo do quilate não tem força bastante para ampliar o rol de mercadorias fixado pela Lei $\mathrm{n}^{\mathbf{0}} 6.374 / 89$, nem para, direta ou obliquamente, atribuir sujeição passiva a ninguém, seja de que espécie for.

Em segundo lugar: se Decreto é ato administrativo da competência privativa do Governador do Estado, se regulamento não pode ser aprovado a não ser por meio de Decreto, se cabia privativamente ao Governador editar regulamento no qual dispostas regras concernentes ao princípio da clareza, nenhuma outra Autoridade poderia fazê-lo. Mais: somente o próprio Governador poderia derrogá-las, ou ab-rogá-las. Por derradeiro e via de consequência: acaso derrogadas, ou ab-rogadas, nenhuma Autoridade poderia revigorá-las.

Não se pretende, aqui, cogitar das intenções da Administração ao empregar tal expediente. Parte-se do pressuposto que foram as melhores. É permitido pensar, no 
entanto, que as mencionadas Portarias carecem de amparo legal, data venia do entendimento expressado pelo Pleno do STF no julgamento da Rp $1.237^{212}$.

Quanto ao Decreto ${ }^{\circ}$ 51.608/07, também o acoimamos de ilegal. As mercadorias nele apontadas não se ajustam àquelas em relação às quais a Lei ${ }^{\circ}$ 6.374/89 estabeleceu aplicável a substituição tributária "para trás". Extrapassado o limite, findou o Decreto por atribuir sujeição passiva por substituição a quem funcione como destinatário nas pertinentes operações, o que não é admissível.

No que tange ao fato de se lançar mão de um Decreto para revogar determinadas regras do RICMS/00 a partir do dia " $x$ " - e mais adiante baixar um Decreto "revigorando" as regras a partir do mesmo dia "x", sem no entanto reincorporá-las ao RICMS/00, nada podemos conjecturar, tal a perplexidade que nos assalta.

Mais não bastassem as ilegalidades, fácil notar que, no curso do tempo, as práticas adotadas pelo Executivo findaram por fragmentar de modo nítido a legislação concernente ao imposto, o que mostra desapreço ao quanto previsto no art. 212 do CTN. Bem por isso é que, examinando esse dispositivo, LuCIANO AMARO diz tratar-se de "norma que tem servido de mero adereço do sistema tributário nacional" ${ }^{213}$.

212 Vide a ementa transcrita na nota de rodapé $\mathrm{n}^{\circ} 7$.

213 Cf. Direito Tributário Brasileiro. 15. ed. São Paulo: Saraiva, 2009, p. 191 


\section{A PRATICABILIDADE E A COMODIDADE COMO MATRIZES INSPIRADORAS DO DIFERIMENTO DO LANÇAMENTO}

Já no Século XVIII, ADAM SMITH cogitara de quatro princípios cuja obediência propunha no campo da imposição de tributos: igualdade, certeza, comodidade e economia $^{214}$. Interessa-nos aqui, sobretudo, lembrar parte do que escreveu a respeito dos dois últimos. Quanto à comodidade, registrou que o tributo deveria ser exigido "no tempo ou da maneira" que se mostrasse mais conveniente para o contribuinte. Quanto à economia, que recomendável não dar causa a "coleta onerosa", não utilizar grande número de funcionários, não prejudicar "a indústria do povo", nem desencorajar investimentos produtivos.

Tendo em mente as "máximas" de ADAM SMITH, parece-nos aconselhável lembrar um claro e sintético entendimento expressado por ViCTOR BorGES POLIZELLI. Segundo o A., um sistema tributário justo e economicamente racional exige que a pertinente legislação seja caracterizada por congruência, continuidade e transparência, bem assim a adoção de "instrumentos de praticabilidade que gerem comodidade e economia da tributação, facilitando a vida tanto dos contribuintes quanto do Fisco." ${ }^{215}$.

A respeito do princípio da praticabilidade, escreveram KLAUS TIPKE e JOACHIM LANG que mesmo uma ordem jurídica impregnada de princípios adequados deve ser prática, não prescindindo a administração tributária, envolvida numa “operação de massa", de normas simplificadoras engendradas com o propósito de "impedir hipercomplicação e intramitabilidade das leis ou despesas administrativas desproporcionadas"216.

Por entendê-la indispensável, vale transcrever a definição atribuída por FRITZ NEUMARK ao princípio da praticabilidade ${ }^{217}$ :

214 Cf. Uma Investigação sobre a Natureza e Causa da Riqueza das Nações. São Paulo: Hemus, 1981, p. 419-421.

215 Cf. A Eficiência do Sistema Tributário - Uma Questão de Busca da Justiça com Proteção da Segurança Jurídica. Direito Tributário Atual, São Paulo, v. 20, p. 253-271 (p. 271), 2006.

216 Cf. Direito Tributário. v. 1. Tradução da 18. ed. alemã por Luiz Dória Furquim. Porto Alegre: Sergio Antonio Fabris, 2008, p. 232.

217 Cf. Principios de la Imposición. Madrid: Instituto de Estudios Fiscales, 1974, p. 424. A tradução do espanhol para o português é de nossa responsabilidade. 
Entendo como princípio da praticabilidade das medidas fiscais o postulado de que se configure a Política Fiscal, em seus princípios gerais e em suas particularidades, de modo a que as ações e objetivos que com ela buscamos satisfaçam a compreensão intelectual e as tendências políticas do contribuinte médio (típico), por um lado, e as atribuições institucionais e materiais dos órgãos de imposição, arrecadação e controle, por outro, tornando-se assim eficazmente aplicáveis e praticáveis.

Pois bem: é generalizado o entendimento segundo o qual a comodidade e a praticidade animaram a implantação do diferimento no seio dos chamados tributos plurifásicos. Se não, vejamos.

Para Regina Helena Costa, "o diferimento do tributo a pagar", que supõe "a tributação plurifásica, como ocorre no ICMS" revela-se como técnica simplificadora, haja vista que "o imposto, ao invés de ser exigido de centenas ou milhares de produtores, é recolhido por um só contribuinte”, o que torna possível diminuir os gastos do Estado com trabalhos de fiscalização, ao demais de torná-los mais simples e eficazes, o que, por sua vez, opera no sentido de "evitar a sonegação"218. JOSÉ EDUARDO SOARES DE MELO tem ponto de vista semelhante: o emprego do diferimento, no campo de "operações de pequeno porte, ou realizadas por contribuintes sem estrutura empresarial, de proporções modestas ou mesmo sem um efetivo estabelecimento", tem como objetivo "a simplificação fiscal de determinadas operações" 219 .

Também Sacha Calmon Navarro CoÊlHo e Eduardo Maneira consideram o diferimento como espécie do gênero "técnicas de simplificação"220.

José RoBerto RosA, por sua vez, afirma que o diferimento é utilizado "com o objetivo de facilitar o controle do imposto",221.

O mesmo entendimento é professado pela CT-SP - e de longa data. Na resposta à consulta $\mathrm{n}^{\mathrm{o}} 11.792$, de 24 de abril de 1978, registrou que o diferimento se revela como

218 Cf. Praticabilidade e Justiça Tributária: Exeqüibilidade de Lei Tributária e Direitos do Contribuinte. São Paulo: Malheiros, 2007, p. 266-268. Grifos no original.

219 Cf. ICMS: teoria e prática. 11 ed. São Paulo: Dialética, 2009, p. 309.

220 Cf. A Substituição Tributária Progressiva e a Cobrança de ICMS sobre Eventual Aumento de Volume de Combustível Decorrente da Variação de Temperatura Ambiente. In: COÊLHO, Sacha Calmon Navarro. Direito Tributário - Temas Atuais. São Paulo: Quartier Latin, 2006, p. 347-369 (p. 360).

221 Cf. Substituição Tributária no ICMS: Manual Explicativo. 2. ed. Itu (SP): Ottoni, 2009, p. 11. 
"medida adotada no interesse do Erário, com o fito de simplificar o controle da arrecadação e a fiscalização do pagamento do imposto"222.

Sucede, no entanto, que o regime de diferimento do lançamento no ICMS do Estado de São Paulo passou a ser empregado, em alguns casos, de modo a pouco lembrar praticidade e comodidade. Se não, analisemos em poucas linhas alguns dos casos nos quais suportada a afirmação.

\subsection{Operações com feijão}

$\mathrm{O}$ primeiro diz com operações relativas à circulação de feijão. $\mathrm{O}$ art. 348 do RICMS $/ 00^{223}$, no seu inc. I, al. "a”, primeira hipótese, dispõe que o lançamento do imposto incidente nas sucessivas saídas de feijão fica diferido para o momento em que ocorrer a entrada no estabelecimento varejista, aí incluídos os restaurantes. Ora, sabendo-se que o número de varejistas que comerciam feijão e de restaurantes sediados no território paulista não é pequeno - fato notório e de conhecimento generalizado, o que não exige prova - o alegado "fito de simplificar o controle da arrecadação e a fiscalização do pagamento do imposto", tal como manifestado pela CT-SP, cai por terra. Praticidade, comodidade e eficiência seriam melhor alcançadas, tudo indica, se atribuído o lançamento do tributo aos estabelecimentos atacadistas que operam no comércio de feijão.

A afirmação fica ainda mais robusta quando se examina o previsto na al. "d" do inc. II do mesmo art. 348: o lançamento do imposto incidente nas sucessivas saídas de

222 Cf. LARANJEIRA, Álvaro Reis (Org.). ICM: Respostas da Consultoria Tributária. v. 2. São Paulo: LTr, 1984, p. 164.

223 Artigo 348 - O lançamento do imposto incidente nas sucessivas saídas de feijão fica diferido para o momento em que ocorrer (Lei 6.374/89, art. $8^{\circ}$, XVII, e $\S 10$, na redação da Lei 9.176/95, art. $1^{\circ}$, I, e 59):

I - a entrada em estabelecimento:

a) varejista, inclusive de restaurante, ou de cooperativa de consumo;

b) industrial, inclusive o que simplesmente acondicionar ou reacondicionar a mercadoria;

II - a saída com destino:

a) ao exterior;

b) a outro Estado;

c) Revogada pelo artigo $3^{\circ}$ do Decreto 52.104, de 29-08-2007; DOE 30-08-2007.

d) a consumidor.

$\S 1^{\circ}$ - Aplica-se o disposto neste artigo a feijão depositado em armazém geral ou em qualquer outro local em nome de estabelecimento ali indicado.

$\S 2^{\circ}$ - Na hipótese do inciso I, o pagamento do imposto deverá ser efetuado no período em que ocorrer a entrada da mercadoria nos estabelecimentos ali indicados, na forma prevista no artigo 116.

$\S 3^{\circ}$ - Revogado pelo artigo $3^{\circ}$ do Decreto 52.104, de 29-08-2007; DOE 30-08-2007. 
feijão fica diferido para o momento em que ocorrer a saída com destino a consumidor. $\mathrm{O}$ raciocínio desenvolvido logo acima, mutatis mutandis, é de ser repetido: sabendo-se que o número de consumidores de feijão vivendo no território paulista não é pequeno - outro fato notório e de conhecimento generalizado - o "fito de simplificar o controle da arrecadação e a fiscalização do pagamento do imposto" - palavras da CT-SP - parece mostrar-se inatingível ${ }^{224}$.

O que se nota, enfim, é que o Poder Executivo preferiu, a um tributo plurifásico, ocupar-se de um monofásico incidente sobre operações de varejo. Escolha arriscada: de acordo com Misabel ABReu MACHADo DeRZI, "a incidência única nas vendas de varejo tem os altos inconvenientes de facilitar a evasão, retardar o recolhimento do imposto para os fiscos e, finalmente, de agregar cumulatividade residual de difícil eliminação"225.

O motivo da escolha do Poder Executivo, não alcançamos conhecê-lo, mas tudo indica não ter relação com praticidade, nem com comodidade.

\subsection{Operações com produtos têxteis}

O segundo exemplo tem com operações relativas à circulação de "produtos têxteis". Examinando-se o art. 400-C do RICMS $/ 00^{226}$, nota-se que seu inc. II determina ficar diferido o lançamento do tributo, "na proporção de 33,33\% (trinta e três inteiros e trinta e três centésimos por cento) do valor da operação", para o momento em que a mercadoria der "saída do estabelecimento comercial". Estão incluídos, no amplo universo, desde simples fios de algodão até fraques, echarpes de seda e tapeçarias.

Aqui também é de se observar a criação de um tributo monofásico incidente sobre operações de varejo. Em parte, decerto, já que o diferimento do lançamento se dá "na proporção de 33,33\% (trinta e três inteiros e trinta e três centésimos por cento) do valor da operação". Uma figura híbrida, é permitido dizer.

\footnotetext{
224 Vale anotar, ainda, que o cotejo do previsto no RICMS/00, art. 348, I, "a", primeira figura, ao disposto no seu inciso II, "d", dá causa a perplexidade: tratando-se de varejistas e restaurantes, o momento no qual o lançamento há de ser levado a efeito é aquele da entrada do feijão na sua órbita jurídica, ou o da saída que promoverem em direção ao consumidor?

225 Cf. Não-Cumulatividade, Neutralidade, PIS e Cofins e a Emenda Constitucional no 42/03. In: ROCHA, Valdir de Oliveira (Coord.). Grandes Questões Atuais do Direito Tributário. São Paulo: Dialética, 2004, v.8, p. 339-355. (p. 339)

226 Ver nota de rodapé $\mathrm{n}^{\circ} 206$.
} 
Diferentemente dos demais casos de diferimento enumerados no RICMS/00, não se cuida de evitar o "lançamento" numa determinada das sucessivas etapas da circulação da mercadoria e deixá-lo para uma das subsequentes. No caso dos "produtos têxteis", lançamento haverá em todas e em cada uma das etapas, só que na mencionada "proporção". É realmente peculiar.

Pois bem: sabendo-se que nas terras paulistas as operações relativas à circulação dos "produtos têxteis" abrangidos no dispositivo sob exame têm o ICMS quantificado de acordo com a aplicação da alíquota de $18 \%$ (dezoito por cento) ${ }^{227}$ à base de cálculo que é o "valor da operação",228, o diferimento do lançamento do imposto, tal como estabelecido, equivale a aplicar uma alíquota de aproximadamente $12 \%$ (doze por cento) ${ }^{229}$ ao "valor das operações" levadas a cabo anteriormente ao momento no qual o "lançamento" se dará "às inteiras" - na falta de melhor expressão -, qual seja o instante em que a mercadoria der "saída do estabelecimento comercial".

Mais não é preciso registrar para se concluir que, por meio do diferimento do lançamento, o Poder Executivo conferiu uma vantagem a certo grupo de agentes econômicos do ramo de "produtos têxteis". Não importa o nome que se queira dar a essa vantagem, mas é certo que calha bem enquadrá-la no conjunto que, de acordo com o inc. IV do parágrafo único do art. $1^{\circ}$ da $\operatorname{LC} \mathrm{n}^{\circ} 24 / 75$, é formado por "quaisquer outros incentivos ou favores fiscais ou financeiro-fiscais, concedidos com base no Imposto de Circulação de Mercadorias, dos quais resulte redução ou eliminação, direta ou indireta, do respectivo ônus".

Não se encontra, aí, nada que se relacione a praticidade, nem a comodidade.

\footnotetext{
227 Tais mercadorias não se incluem dentre as exceções de que se cuida no art. 34 da Lei n 6.374/89, daí que a alíquota a ser aplicada é a prevista no inc. I do mesmo artigo, qual seja 18\% (dezoito por cento).

228 A legislação paulista não prevê nenhuma redução da base de cálculo no respeitante a essas operações, daí que, na conformidade do art. 24, inc. I, da Lei $n^{\circ} 6.374 / 89$, é de se observar, na quantificação do ICMS, o "valor da operação".

229 Mais exatamente: $12,0006 \%$ (doze inteiros e seis décimos de milésimos por cento).
} 


\section{A INOBSERVÂNCIA DO PRINCÍPIO DA CLAREZA}

Segundo Nicola abBagnano, (i) o termo cultura pode ser empregado para indicar "o conjunto dos modos de vida de um grupo humano determinado, sem referência ao sistema de valores para os quais estão orientados esses modos de vida" ${ }^{230}$, e (ii) civilização é o "conjunto de instrumentos de que uma cultura dispõe para conservar-se, enfrentar os imprevistos de situações novas e perigosas, superar a crise, renovar-se e progredir" $^{231}$.

Pois bem. O Brasil inclui-se dentre os países caracterizados por experimentarem uma cultura que, nos dias de hoje, confere ao tributo o papel de instrumento de realização das tarefas finais do Estado. Perenizar esse traço cultural - tendo em mente que nenhuma cultura é imóvel no tempo, mas dotada de equilíbrio instável e dinâmico - exige o manuseio de instrumentos que integrem o conjunto ao qual, aderindo a NiCOLA ABBAGNANO, chamamos de civilização.

O Direito Tributário Brasileiro, objeto cultural que é, não prescinde da observância de uma série de princípios, balizas estas que não passam de espécies dos instrumentos componentes do conjunto civilização. Sabendo-se que a realização das tarefas finais do Estado exige o prévio adimplemento do dever de contribuir, o mínimo que se pode exigir é que a legislação tributária seja elaborada de modo a serem respeitados os princípios consagrados na Constituição Federal, dentre os quais os da segurança jurídica e da legalidade são os que mais de perto interessam ao tema sob exame, bem assim de forma a que o sujeitado possa bem compreendê-la.

São conhecidas as dificuldades que cercam a "interpretação e aplicação da lei". No correr de séculos, numerosas escolas se debruçaram sobre o tema e também numerosos foram os métodos e meios alvitrados pelos estudiosos para que se proceda ao bem interpretar. A literatura acerca do tema é das mais fartas. Nada obstante, pouca atenção é dada às dificuldades que, no âmbito da interpretação da lei, são engendradas pelos que a elaboram quando deixam de primar pela clareza.

230 Cf. CULTURA. In: Dicionário de Filosofia. 5. ed., São Paulo: Martins Fontes, 2007, p. 261-265.

231 Cf. CIVILIZAÇÃO. Idem, p. 168-169. 
Textos normativos que não se revelem suficientemente claros impedem, ou dificultam, que se cumpra o dever de contribuir, mesmo porque podem dar a alguém a idéia de que o comando não lhe diz respeito. Demais disso, textos do naipe põem em risco os princípios da segurança jurídica e da legalidade, tudo conspirando em desfavor da justiça tributária.

RiCARDO LOBO TORRES, ensinando que legitimação é o processo de justificação da Constituição e dos seus princípios fundamentais, enumera (i) ponderação, (ii) razoabilidade, (iii) igualdade, (iv) transparência e (v) clareza como princípios de legitimação do ordenamento constitucional-tributário brasileiro. Segundo o doutrinador, o princípio da clareza, ou da simplicidade, "sinaliza no sentido de que o direito tributário deve ser claro, simples, exato, determinado, correto do ponto de vista vernacular e sem contradições em sua enunciação", conjunto de elementos na ausência dos quais finda o próprio contribuinte por não conhecer "em toda a sua extensão o conteúdo do dever de pagar o tributo". O princípio da clareza, desde que observado, robora os princípios da segurança jurídica e da legalidade. Ignorado, resta enfraquecido o próprio Estado Democrático de Direito. É o que pode suceder, por exemplo, nos casos de (i) inflação normativa e excesso de regulamentação, (ii) excesso de preciosismo no texto legal, (iii) manipulação do texto pelos políticos e pelos funcionários da Fazenda, (iv) emprego de linguagem técnica que dificulte a compreensão do leigo, (v) abuso na utilização de tipos e conceitos indeterminados ${ }^{232}$.

O Estado Democrático de Direito pressupõe o respeito às normas jurídicas, o que, por sua vez, impõe que os textos por meio dos quais trazidas à luz findem compreendidos pelos destinatários. Na redação desses textos, atribuída tanto ao Poder Legislativo quanto ao Executivo e ao Judiciário, de acordo com a competência a cada um deles conferida pela CF de 1988, há de ser levado em conta o atributo da clareza, haja vista a necessidade de se possibilitar sua compreensão por todos aqueles que devem conhecê-los.

O descuido na elaboração dos textos, tanto em seu aspecto formal, quanto estrutural, é bastante para abalar a própria segurança jurídica e malferir o princípio da legalidade. Não é raro observar, lamentavelmente, que excessivo ânimo de legislar, conjugado a despreparo técnico, resulte na produção de textos maculados (i) de erros,

232 Cf. Tratado de Direito Constitucional Financeiro e Tributário - Valores e Princípios Constitucionais Tributários. v. II. Rio de Janeiro: Renovar, 2005, v. II, p. 262-266. 
incompatibilidades, impropriedades, inconsistências, incongruências e ambiguidades, ou (ii) de complexidade desamparada de autêntico interesse geral, o que facilmente se revela quando dizem respeito a múltiplos assuntos e, por conseguinte, veiculam conjuntos de regras que não guardam estreita relação umas com as outras.

Lamentavelmente, não é difícil encontrar exemplos de manifestas ofensas ao princípio da clareza no seio da legislação paulista destinada a regular a tributação de operações relativas à circulação de mercadorias por intermédio do regime do diferimento do lançamento. Se não, vejamos.

\subsection{Operações com aves}

$\mathrm{O}$ art. 363 do RICMS $/ 00^{233}$ diz com operações relativas à circulação de aves. Dentre as inúmeras hipóteses nele contempladas, está previsto no seu inc. II, al. "a”, que o lançamento do ICMS fica diferido para o momento no qual se der "a saída de aves abatidas ou produtos comestíveis resultantes de sua matança, em estado natural, resfriados, congelados ou simplesmente temperados, do estabelecimento abatedor”. Sucede que no Anexo $\mathrm{I}^{234}$ do mesmo Regulamento está registrado que exoneradas do pagamento do tributo, por meio de isenção, "as saídas internas de (...) ave viva, de produção paulista,

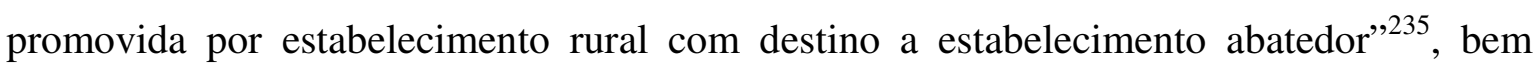

233 Artigo 363 - O lançamento do imposto incidente nas sucessivas saídas de aves fica diferido para o momento em que ocorrer (Lei 6.374/89, art. $8^{\circ}$, XVII e $\S 10$, na redação da Lei 9.176/95, art. $1^{\circ}$, I, e 38, $\left.\S 6^{\circ}\right)$

I - saída de aves vivas com destino:

a) a outro Estado;

b) ao Exterior;

c) a consumidor;

II - a saída:

a) de aves abatidas ou produtos comestíveis resultantes de sua matança, em estado natural, resfriados, congelados ou simplesmente temperados, do estabelecimento abatedor;

b) de preparações ou conservas de carnes ou produtos comestíveis resultantes de sua matança, do estabelecimento industrializador;

III - o fornecimento, como alimentação, de produtos comestíveis resultantes de sua matança, em restaurante ou estabelecimento similar.

$\S 1^{\circ}$ - Aplica-se o diferimento previsto neste artigo ao recebimento decorrente de importação do exterior de pintos de um dia e de avestruz.

234 No Anexo I do RICMS/00 estão elencadas as operações relativas à circulação de mercadorias e prestações de serviços isentas do imposto.

235 RICMS/00, Anexo I, art. 101:

Artigo 101 (COELHO E AVE) - As operações seguintes (Lei 6.374/89, art. 112 ): (Acrescentado pelo inciso IV do art. $1^{\circ}$ do Decreto 48.114, de 26-09-2003; DOE 27-09-2003; efeitos a partir de 27-09-2003) I - as saídas internas de coelho vivo ou ave viva, de produção paulista, promovida por estabelecimento rural com destino a estabelecimento abatedor; 
assim "a saída interna de carne e demais produtos comestíveis frescos, resfriados, congelados, salgados, secos ou temperados, resultantes do abate de aves (...),236.

Pois bem: para facilitar o raciocínio, chamemos de etapa 1 a operação no bojo da qual a ave viva é remetida por estabelecimento rural a determinado estabelecimento abatedor; de etapa 2 a operação na qual, já abatida a ave, sua carne é vendida a estabelecimento varejista - e, por fim, de etapa 3 a operação por meio da qual o varejista vende a carne para o consumidor final.

Ora, observados os arts. 101, inc. I, e 144, ambos do Anexo I do RICMS/00, as ditas etapas 1, 2 e 3 estão desoneradas do ICMS, daí que não há falar em lançamento do tributo, seja ele diferido, ou não. Síntese: o cotejo do quanto previsto no Anexo I do RICMS/00, arts. 101, inc. II, e 144, de um lado, ao quanto estabelecido na al. "a" do inc. II do art. 363 do corpo do mesmo RICMS/00, de outro lado, revela aptidão bastante para induzir perplexidade na mente do particular, o que, por óbvio, traduz desrespeito ao princípio da clareza.

\subsection{Operações com cominho}

Falta igualmente grave diz respeito às operações relativas à circulação de cominho em estado natural. Prevê o RICMS/00, no inc. III do art. 36 do seu Anexo ${ }^{237}$, que as

II - o desembaraço aduaneiro decorrente de operação de importação direta realizada por estabelecimento rural paulista, de pinto de um dia e de avestruz.

$\S 1^{\circ}$ - Na hipótese de que trata o inciso II, o benefício fica condicionado a que o desembarque e desembaraço aduaneiro ocorram em território paulista.

$\S 2^{\circ}$ - Não se exigirá o estorno do crédito do imposto relativo às mercadorias beneficiadas com a isenção prevista neste artigo., inc. I.

236 RICMS/00, Anexo I, art. 144:

Artigo 144 (CARNE) - A saída interna de carne e demais produtos comestíveis frescos, resfriados, congelados, salgados, secos ou temperados, resultantes do abate de aves, leporídeos e gado bovino, bufalino, caprino, ovino e suíno (Convênio ICMS-89/05, cláusula segunda e artigo 112 da Lei 6.374/89). (Artigo acrescentado pelo Decreto 54.643, de 05-08-2009, DOE 06-08-2009; Efeitos para os fatos geradores ocorridos a partir de $1^{\circ}$ de setembro de 2009)

Parágrafo único - Não se exigirá o estorno do crédito do imposto correspondente à entrada de gado bovino ou suíno em pé, relacionada à isenção prevista neste artigo.

237 Artigo 36 (HORTIFRUTIGRANJEIROS) - Operações com os seguintes produtos em estado natural, exceto quando destinados à industrialização (Convênio ICM-44/75, com alteração dos Convênios ICM20/76, ICM-7/80, cláusula primeira, ICM-24/85, ICM-30/87, ICMS-68/90 e ICMS-17/93, e Convênio ICMS-124/93, cláusula primeira, V, 2): (Redação dada ao "caput" pelo Decreto 52.836, de 26-03-2008; DOE 27-03-2008)

(omissis)

III - cacateira, cambuquira, camomila, cará, cardo, catalonha, cebola, cebolinha, cenoura, chicória, chuchu, coentro, cogumelo, cominho, couve e couve-flor; 
operações relativas à circulação de cominho em estado natural são isentas do tributo, salvo quando destinado à industrialização. Acontece que o mesmo Regulamento dispõe, no seu art. $352^{238}$, que o lançamento do imposto incidente nas operações com cominho fica diferido para o momento em que ocorrer "sua saída para outro Estado", ou "sua saída para o exterior", ou "sua saída do estabelecimento varejista", ou "a saída dos produtos resultantes de sua industrialização". É digna de nota a incompatibilidade: ressalvadas as operações por meio das quais o cominho tenha a industrialização como destino, todas as demais estão isentas do tributo, daí que, nestas últimas, não há falar em lançamento, seja ele diferido, ou não.

\subsection{Operações com gado bovino e suíno}

Dispõe o inc. II do art. $364^{239}$ do RICMS/00 que "o lançamento do imposto incidente nas sucessivas operações com gado em pé bovino ou suíno fica diferido para o momento em que ocorrer a saída de produtos comestíveis resultantes de seu abate, de estabelecimento frigorífico ou de qualquer outro que promova o abate, ainda que submetidos a outros processos industriais". Sucede que no art. 102 do Anexo I do mesmo Regulamento está escrito que "a saída interna de gado de qualquer espécie promovida por estabelecimento rural com destino a estabelecimento abatedor" é isenta do ICMS - e, no art. 144 do mesmo Anexo I, que a "saída interna de carne e demais produtos comestíveis frescos, resfriados, congelados, salgados, secos ou temperados”, resultantes do abate, dentre outros, de gado bovino e suíno também são isentas do ICMS. Serve aqui, mutatis

238 Artigo 352 - O lançamento do imposto incidente nas operações com cominho fica diferido para o momento em que ocorrer (Lei 6.374/89, art. $8^{\circ}$, XVII e $\S 10$, na redação da Lei 9.176/95, art. $1^{\circ}$, I): (Redação dada ao artigo 352 pelo inciso V do artigo $1^{\circ}$ do Decreto 45.644 de 26/01/2001; DOE 27/01/2001; efeitos a partir de 01/01/2001)";

I - sua saída para outro Estado;

II - sua saída para o exterior;

III - sua saída do estabelecimento varejista;

IV - a saída dos produtos resultantes de sua industrialização.

239 Artigo 364 - O lançamento do imposto incidente nas sucessivas operações com gado em pé bovino ou suíno fica diferido para o momento em que ocorrer: (Lei 6.374/89, art. $8^{\circ}$, XVII, § 10, na redação da Lei 9.176/95, art. $\left.1^{\circ}, \mathrm{I}\right)$ :

I - a saída de gado em pé com destino:

a) a outro Estado;

b) ao exterior;

c) a consumidor;

II - a saída de produtos comestíveis resultantes de seu abate, de estabelecimento frigorífico ou de qualquer outro que promova o abate, ainda que submetidos a outros processos industriais;

III - a saída dos subprodutos da sua matança referidos no artigo 383. 
mutandis, o mesmo raciocínio que desenvolvemos no tópico referente a aves. A conclusão há de ser semelhante: o cotejo do quanto previsto no Anexo I do RICMS/00, arts. 102 e 144, de um lado, ao quanto estabelecido no inc. II do art. 364 da "parte geral" do mesmo RICMS/00, de outro lado, revela aptidão bastante para induzir perplexidade na mente do particular, o que, certo está, traduz desrespeito ao princípio da clareza.

\subsection{Operações com insumos agropecuários}

As operações relativas à circulação dos bens listados nos arts. 355 a 361, operações estas que se cogitou de submeter ao regime de diferimento do lançamento do tributo, não se encontram a ele submetidas. É que prevalece o disposto no artigo 17 das Disposições Transitórias do RICMS $/ 00^{240}$.

Ora, é de se afirmar: se estava previsto, desde o aparecimento do RICMS/00, que tais operações estavam abrigadas da incidência do ICMS por meio de isenção, não há nenhum motivo razoável para manter, no corpo do diploma, os dispositivos que se referem a diferimento do lançamento. Alguém dirá que estão ali para prevalecerem quando forem revogadas, quem sabe, as normas isentivas. A objeção não procede: desde que revogada a isenção, nada impediria que fossem acrescentados ao regulamento normas que dissessem com diferimento do lançamento. A permanência, no corpo do RICMS/00, dos arts. 355 a 361 não se mostra útil: presta-se tão-só para induzir perplexidades.

\subsection{Operações com leite}

Dispõe o RICMS/00, no parágrafo único do seu art. 389, que nas sucessivas "saídas" de leite cru, pasteurizado ou reidratado, quando se tratar de leite pasteurizado tipo especial, com 3,2\% de gordura, leite pasteurizado magro, reconstituído ou não, com até $2 \%$ de gordura, ou leite pasteurizado tipo "A" ou "B", o lançamento do imposto fica diferido para o momento no qual se der a "saída para consumidor final". Ocorre que tal "saída" é isenta de ICMS, consoante o disposto na cabeça do art. 43 do Anexo I do mesmo RICMS/00, estando dispensado o "pagamento do imposto eventualmente diferido quando a

240 Ver nota de rodapé no 204. 
operação estiver abrangida por este benefício", conforme previsto no item “2” do parágrafo único do mesmo art. 43.

Ora bem: se a "saída para consumidor final" é isenta do tributo e as operações antecedentes não resultam no dever de pagar nada a título de imposto, não há falar em lançamento, seja diferido, ou não. Fácil notar que o art. 389, parágrafo único, do RICMS/00 não serve para mais nada que não seja deixar perplexo o varejista de leite que se ocupe de examiná-lo, caso lhe ocorra examinar, também, o art. 43 do Anexo I do mesmo diploma regulamentar.

\subsection{A lição do Conselho Constitucional Francês}

\section{O Conselho Constitucional da República Francesa, instituído pela Constituição de} 4 de outubro de 1958 (artigos 56 a 63) 241 $^{24}$, não integra o universo dos tribunais franceses,

241 CONSTITUTION DE 1958

Article 56. - Le Conseil constitutionnel comprend neuf membres, dont le mandat dure neuf ans et n'est pas renouvelable. Le Conseil constitutionnel se renouvelle par tiers tous les trois ans. Trois des membres sont nommés par le Président de la République, trois par le président de l'Assemblée nationale, trois par le président du Sénat. La procédure prévue au dernier alinéa de l'article 13 est applicable à ces nominations. Les nominations effectuées par le président de chaque assemblée sont soumises au seul avis de la commission permanente compétente de l'assemblée concernée.

En sus des neuf membres prévus ci-dessus, font de droit partie à vie du Conseil constitutionnel les anciens Présidents de la République.

Le président est nommé par le Président de la République. Il a voix prépondérante en cas de partage.

Article 57. - Les fonctions de membre du Conseil constitutionnel sont incompatibles avec celles de ministre ou de membre du Parlement. Les autres incompatibilités sont fixées par une loi organique.

Article 58.

Le Conseil constitutionnel veille à la régularité de l'élection du Président de la République.

Il examine les réclamations et proclame les résultats du scrutin.

Article 59. - Le Conseil constitutionnel statue, en cas de contestation, sur la régularité de l'élection des députés et des sénateurs.

Article 60. - Le Conseil constitutionnel veille à la régularité des opérations de référendum prévues aux articles 11 et 89 et au titre XV. Il en proclame les résultats.

Article 61. - Les lois organiques, avant leur promulgation, les propositions de loi mentionnées à l'article 11 avant qu'elles ne soient soumises au référendum, et les règlements des assemblées parlementaires, avant leur mise en application, doivent être soumis au Conseil constitutionnel qui se prononce sur leur conformité à la Constitution.

Aux mêmes fins, les lois peuvent être déférées au Conseil constitutionnel, avant leur promulgation, par le Président de la République, le Premier ministre, le président de l'Assemblée nationale, le président du Sénat ou soixante députés ou soixante sénateurs.

Dans les cas prévus aux deux alinéas précédents, le Conseil constitutionnel doit statuer dans le délai d'un mois. Toutefois, à la demande du Gouvernement, s'il y a urgence, ce délai est ramené à huit jours.

Dans ces mêmes cas, la saisine du Conseil constitutionnel suspend le délai de promulgation.

Article 61-1. - Lorsque, à l'occasion d'une instance en cours devant une juridiction, il est soutenu qu'une disposition législative porte atteinte aux droits et libertés que la Constitution garantit, le Conseil constitutionnel peut être saisi de cette question sur renvoi du Conseil d'État ou de la Cour de cassation qui se prononce dans un délai déterminé. 
nem judiciários, nem administrativos. Dentre suas competências, todavia, encontra-se uma forma sui generis de controle abstrato de constitucionalidade. De acordo com a segunda alínea do artigo 61 da Constituição, podem ser submetidas a controle de constitucionalidade as leis ordinárias que, votadas pelo Parlamento, ainda não tenham sido promulgadas, desde que provocado o Conselho pelo Presidente da República, ou pelo Primeiro Ministro, ou pelo Presidente da Assembléia Nacional, ou pelo Presidente do Senado, ou por 60 deputados, ou por 60 senadores. Realizado o controle de constitucionalidade, é do artigo 62 da Constituição que (i) qualquer disposição declarada inconstitucional pelo Conselho não há de ser promulgada, nem posta em aplicação, bem assim que (ii) tal espécie de decisão é insuscetível de recurso e se impõe a todas as autoridades administrativas e "jurisdicionais".

Pois bem. Provocado por 130 (cento e trinta) deputados, tratou o Conselho Constitucional de proceder ao controle de constitucionalidade de certo número de disposições vertidas na Lei de Finanças de 2006, diploma votado no âmbito da Assembléia Nacional, mas ainda não promulgado naquela oportunidade. Dentre as disposições alvo do descontentamento dos deputados, interessa ao tema ora examinado o quanto dizia respeito ao artigo 78 da mencionada lei. O dispositivo, longo de 9 (nove) páginas e 14801 (catorze mil, oitocentos e um) caracteres $^{242}$, pretendia dispor acerca da fixação de um limite superior quanto ao aproveitamento de "vantagens fiscais" (avantages fiscaux) no âmbito do imposto de renda de pessoas físicas, o que viria a irradiar reflexos na quantificação do montante a pagar. Com o fim de conhecer qual fosse o melhor modo de tirar proveito dessas "vantagens fiscais" e, por conseguinte, não pagar mais do que o estritamente exigido pela legislação, caberia ao sujeito passivo (i) proceder ao exame de dispositivos que

Une loi organique détermine les conditions d'application du présent article.

Article 62. - Une disposition déclarée inconstitutionnelle sur le fondement de l'article 61 ne peut être promulguée ni mise en application.

Une disposition déclarée inconstitutionnelle sur le fondement de l'article 61-1 est abrogée à compter de la publication de la décision du Conseil constitutionnel ou d'une date ultérieure fixée par cette décision. Le Conseil constitutionnel détermine les conditions et limites dans lesquelles les effets que la disposition a produits sont susceptibles d'être remis en cause.

Les décisions du Conseil constitutionnel ne sont susceptibles d'aucun recours. Elles s'imposent aux pouvoirs publics et à toutes les autorités administratives et juridictionnelles.

Article 63. - Une loi organique détermine les règles d'organisation et de fonctionnement du Conseil constitutionnel, la procédure qui est suivie devant lui et notamment les délais ouverts pour le saisir de contestations.

Disponível em <http://www.legifrance.gouv.fr/html/constitution/constitution.htm>. Acesso em 10 abril 2009

242 Cf. Commentaire aux cahiers. Disponível em <http://www.conseil-constitutionnel.fr/conseilconstitutionnel/francais/les-decisions/depuis-1958/decisions-par-date/2005/2005-530-dc/commentaireaux-cahiers.13080.html>. Acesso em 15 abril 2009. 
enviavam a outros e (ii) elaborar cálculos preliminares que, à míngua de absoluta segurança, revelariam arbitramento.

Examinada a matéria, o Conselho decidiu ${ }^{243}$ de acoimar o dispositivo de inconstitucional, valendo destacar, da respectiva fundamentação, os seguintes elementos:

a) a lei "fiscal", quando alcança um nível de complexidade tal que se torna ininteligível para o cidadão, ignora o artigo 14 da Declaração de 1789, nos termos do qual "Todos os cidadãos têm o direito de constatar, por eles mesmos, ou por seus representantes, a necessidade da contribuição pública, de com ela consentir livremente, de seguir seu emprego e de determinar sua cotização, sua base imponível, seu recolhimento e sua duração";

b) os destinatários das disposições examinadas não eram apenas a administração fiscal, mas também os contribuintes, chamados a calcular previamente o montante de seu imposto a fim de avaliar a incidência sobre suas escolhas das novas regras de fixação do limite superior de aproveitamento de "vantagens fiscais";

c) a complexidade das regras que se pretendia impor, traduzidas notadamente (i) pelo comprimento do dispositivo, (ii) pelo caráter imbricado de suas disposições, tornando-as incompreensíveis para o contribuinte - e por vezes ambíguas para o profissional, bem assim (iii) pelos numerosos reenvios que se previa a outras disposições igualmente imbricadas, resultavam em incertezas que seriam fonte de insegurança jurídica, mal-entendidos, reclamações e litígios;

d) o nível de complexidade do dispositivo poderia dar azo a que uma parcela dos contribuintes implicados não se mostrasse em condições de proceder aos cálculos preliminares excogitados pelo legislador;

e) a excessiva complexidade do dispositivo não encontrava sua contrapartida em nenhum motivo de autêntico interesse geral.

243 Décision $n^{\circ}$ 2005-530 DC du 29 décembre 2005. Disponível em <http://www.conseilconstitutionnel.fr/conseil-constitutionnel/francais/les-decisions/depuis-1958/decisions-par-date/2005/ 2005-530-dc/decision-n-2005-530-dc-du-29-decembre-2005.975.html>. Acesso em 15 abril 2009. 
A lição do Conselho Constitucional Francês bem sublinha a importância que o elaborador de textos normativos, seja integrante do Poder Legislativo, ou do Executivo, ou do Judiciário, deve atribuir a algo que, tudo indica, não vem constando, ao menos ininterruptamente, de suas preocupações: os textos que redige com o fim de disciplinar matéria de cunho tributário não têm como destinatários tão somente os especialistas que dedicam sua energia vital a esta parte da experiência humana, mas também - e especialmente - os leigos que terão o resultado de suas atividades onerado pelos tributos.

\subsection{Nossas conjecturas}

É do inciso II do artigo $5^{\circ}$ da Constituição Federal que "ninguém será obrigado a fazer ou deixar de fazer alguma coisa senão em virtude de lei". Necessário, portanto, que se compreenda a lei, o que, por sua vez, exige que sua elaboração leve em conta, dentre numerosos outros, o princípio da clareza. Cuida-se de uma das unidades do conjunto de instrumentos que, aderindo a NiCOLA ABBAGNANO, designamos de civilização.

Sucede que o princípio da clareza nem sempre é obedecido, tal como diagnosticamos ao examinar certas das regras tocantes ao diferimento do lançamento encartadas no RICMS/00.

O desrespeito ao princípio da clareza não é apanágio dos elaboradores de textos normativos brasileiros. Como vimos, tropeço do naipe, de autoria da Assembléia Nacional da França, foi cominado de inconstitucionalidade pelo seu Conselho Constitucional. Tratase de decisão cuja leitura recomenda-se vivamente aos que se ocupam de elaborar textos normativos no Brasil. 


\section{O DIFERIMENTO E A LIVRE CONCORRÊNCIA}

Cuidando-se de princípio normativo formulado expressamente na CF de 1988 (art. 170, IV), a livre concorrência tem caráter estrutural, básico e fundamental. Nada obstante enumerado dentre aqueles que informam a Ordem Econômica, é seguro que tem relação íntima com os princípios e regras pertinentes à Ordem Tributária. Certo está que a obediência a ambos os conjuntos de princípios e regras há de ter lugar de forma harmoniosa, de modo que a livre concorrência não implique ofensa à tributação - e viceversa. A livre concorrência não há de ser transformada em obstáculo à concretização dos princípios e regras constitucionais que norteiam a tributação. Em contrapartida: seja no que diz respeito à criação de tributos, seja no que se refere à exigência de seu pagamento, é seguro que a tributação não pode ter lugar sem que se leve em conta seus reflexos na seara da concorrência. Levada em conta essa inter-relação, mostra-se relevante cogitar acerca dos efeitos, na concorrência estabelecida entre os agentes econômicos, do "diferimento do lançamento" constante da legislação paulista do ICMS.

É certo que, tendo em conta determinada categoria de agentes econômicos, o STF deixou assentado, na Rp 1.237, que a implantação do diferimento no âmbito do ICM não implicava, "no contexto global da competição econômica, desfavorecer os seus homólogos nos outros Estados da Federação" ${ }^{, 244}$. Cuida-se de decisão proferida nos idos de 1985 , quando o Direito Concorrencial ainda mal engatinhava no Brasil. Agora que já caminha a passos largos, parece recomendável que se torne ao assunto. É o que se passa a fazer.

\subsection{A livre concorrência}

Estabelece a CF de 1988, no seu art. $1^{\circ}$, que a República tem como fundamentos: a soberania (inc. I), a cidadania (inc. II), a dignidade da pessoa humana (inc. III), os valores sociais do trabalho e da livre iniciativa (inc. IV) e o pluralismo político (inc. V). No seu art. $3^{\circ}$, assenta que a República tem como objetivos: construir uma sociedade livre, justa e solidária (inc. I), garantir o desenvolvimento nacional (inc. II), erradicar a pobreza e a

244 Trecho extraído do voto do Relator, Min. Francisco Rezek, condutor do acórdão cuja ementa consta da nota de rodapé $n^{\circ} 7$. 
marginalização e reduzir as desigualdades sociais e regionais (inc. III), promover o bem de todos, sem preconceitos de origem, raça, sexo, cor, idade e quaisquer outras formas de discriminação (inc. IV).

Assentados esses fundamentos e objetivos, trata a CF de 1988 de fixar que a ordem econômica é fundada na valorização do trabalho humano e na livre iniciativa - e tem por fim assegurar a todos existência digna, conforme os ditames da justiça social, observados os princípios da soberania nacional, propriedade privada, função social da propriedade, livre concorrência, defesa do consumidor e do meio ambiente, redução das desigualdades regionais e sociais, busca do pleno emprego e tratamento favorecido para as empresas de pequeno porte constituídas sob as leis brasileiras e que tenham sua sede e administração no País, ficando assegurado a todos o livre exercício de qualquer atividade econômica, independentemente de autorização de órgãos públicos, salvo nos casos previstos em lei (art. 170).

Considerados esses dispositivos constitucionais, importa sublinhar que o alvo mirado pela ordem econômica é "assegurar a todos existência digna, conforme os ditames da justiça social", o que se confunde com fundamento da própria República, qual seja o da "dignidade da pessoa humana". Visando a assegurar existência digna a todos, a ordem econômica não passa, enfim, de instrumento utilizável para que se alcancem os objetivos listados no art. $3^{\circ}$ da Carta da República.

Destaque-se, outrossim, que a valorização do trabalho humano e a iniciativa privada são, ambas, fundamentos da República (CF de 1988, art. 1º IV) e também da ordem econômica (CF de 1988, art. 170, cabeça). Convém anotar, desde já, que a livre iniciativa de que se cuida no texto constitucional diz especificamente com a liberdade econômica ou de iniciativa econômica; em outros termos, com a liberdade de comércio e indústria.

Pois bem: eleito o modo de produção capitalista, atribuída a exploração da atividade econômica aos agentes privados, foi ressalvada, contudo, a participação direta do Estado quando necessária aos imperativos da segurança nacional ou a relevante interesse coletivo, conforme definidos em lei (CF de 1988, art. 173, cabeça). Ficou estabelecido no texto constitucional, ainda, que: 
a) como agente normativo e regulador da atividade econômica, o Estado exercerá, na forma da lei, as funções de fiscalização, incentivo e planejamento, sendo este determinante para o setor público e indicativo para o setor privado (art. 174, cabeça);

b) o mercado interno integra o patrimônio nacional e será incentivado de modo a viabilizar o desenvolvimento cultural e sócio-econômico, o bemestar da população e a autonomia tecnológica do País, nos termos de lei federal (art. 219).

Prossigamos. Relembrando-se que o objetivo colimado pelo ordem econômica é "assegurar a todos existência digna, conforme os ditames da justiça social", fácil observar que a livre iniciativa não passa de um de seus fundamentos - e a livre concorrência de um de seus princípios informadores. Em outras palavras: a livre iniciativa e a livre concorrência não são finalidades da ordem econômica.

Nada obstante possam ser vistos como conceitos complementares, livre iniciativa e livre concorrência não se confundem.

Segundo FERNANDO FACURY SCAFF ${ }^{245}$, a livre iniciativa "decorre de um primado de Liberdade", ao passo que a livre concorrência "funda-se primordialmente na Isonomia, e não na Liberdade (a qual, embora não esteja afastada, não é primordial)". A aspiração da primeira é permitir a todo agente econômico, público ou privado, pessoa física ou jurídica, que exerça, nos limites da lei, atividade econômica no sentido amplo. Ambição da segunda: estabelecer condições para que se implemente um ambiente de concorrência perfeita no mercado. Segundo InOCÊNCIO MÁRTIRES COELHO ${ }^{246}$, a livre iniciativa é projeção da liberdade individual no plano da produção, circulação e distribuição das riquezas e visa a assegurar a livre escolha das profissões e das atividades econômicas, bem assim a autonomia na escolha dos meios e processos vocacionados a atingir os fins pretendidos, enquanto a livre concorrência tem caráter instrumental e visa a assegurar que os preços de mercadorias e bens resulte do livre jogo das forças em disputa de clientela na economia de mercado.

245. Cf. Efeitos da Coisa Julgada em Matéria Tributária e Livre Concorrência. In: ROCHA, Valdir de Oliveira (Coord.). Grandes Questões Atuais do Direito Tributário. São Paulo: Dialética, 2005, v. 9, p. 110-135 (p. 114-115).

246 Cf. A Defesa da Livre Concorrência na Constituição de 1988. Arquivos do Ministério da Justiça, Brasília, v. 47, n. 184, p. 5-18 (p. 17), jul./dez. 1994. 
Como ensina ERos RoBerto GRAU ${ }^{247}$, a livre concorrência deriva da liberdade de iniciativa econômica - e funciona como elemento moderador desta. Não há de ser encarada como um "princípio negativo", pois é, na essência, uma liberdade privada de índole positiva, "expressando-se como direito a que o abuso (deslealdade) da liberdade de comércio e indústria não comprometa o funcionamento regular dos mercados".

Dessa breves notas tira-se uma conclusão: a livre iniciativa, malgrado fundamento da República e da ordem econômica, deve ser exercida de modo a que sejam preservados de lesão o mercado interno e o princípio da livre concorrência. O mesmo é de se dizer acerca da concorrência: seu exercício deve ter lugar sem que se desrespeite a livre iniciativa e o mercado interno.

\subsection{A proteção da livre concorrência}

No Brasil, a proteção da livre concorrência é edificada sobre extenso rol de normas.

Ficou determinado, no art. $173, \S 4^{\circ}$, da CF de 1988 , que a lei reprimirá o abuso do poder econômico que vise à dominação dos mercados, à eliminação da concorrência e ao aumento arbitrário dos lucros.

Também com o fim de proteger a livre concorrência, decidiu o Poder Constituinte Derivado, por meio da Emenda $\mathrm{n}^{\circ} 42$, de 19 de dezembro de 2003, de acrescentar ao texto original da CF de 1988 o seu art. 146-A ${ }^{248}$.

No plano infraconstitucional, destacam-se (i) a Lei $n^{\circ} 8.137 / 90$, que dispõe nos seus $\operatorname{artigos} 4^{\circ}, 5^{\circ}$ e $6^{\circ}$, a respeito de crimes contra a ordem econômica, e (ii) a Lei n ${ }^{\circ} 8.884 / 94$.

Foi conferido à Lei $n^{\circ} 8.884 / 94$ o propósito de regular a proteção administrativa da livre concorrência. Não é o único: como está na cabeça do seu art. $1^{\circ}$, o diploma "dispõe sobre a prevenção e a repressão às infrações contra a ordem econômica, orientada pelos ditames constitucionais de liberdade de iniciativa, livre concorrência, função social da propriedade, defesa dos consumidores e repressão ao abuso do poder econômico".

247 Cf. Princípio da Livre Concorrência - Função Regulamentar e Função Normativa. Revista Trimestral de Direito Público, São Paulo, v. 93, n. 4, p. 104-129 (p. 124-126), 1993.

248 Art. 146-A. Lei complementar poderá estabelecer critérios especiais de tributação, com o objetivo de prevenir desequilíbrios da concorrência, sem prejuízo da competência de a União, por lei, estabelecer normas de igual objetivo. 
Importa destacar que logo adiante, no parágrafo único do mesmo art. $1^{\circ}$, enuncia-se que "A coletividade é a titular dos bens jurídicos protegidos por esta lei".

Ao demais de fixar regras concernentes às atribuições e ao funcionamento do CADE, bem assim a respeito de atos de concentração empresarial, temas que fogem ao escopo deste trabalho, a Lei $n^{\circ} 8.884 / 94$ estabelece, no seu art. 20, que constituem infração da ordem econômica, independentemente de culpa, os atos que, sob qualquer forma manifestados, tenham por objeto ou possam produzir os efeitos de que se cuida nos seus incisos, ainda que tais efeitos não sejam alcançados. São eles: limitar, falsear ou de qualquer forma prejudicar a livre concorrência ou a livre iniciativa (inc. I), dominar mercado relevante de bens ou serviços (inc. II), aumentar arbitrariamente os lucros, (inc. III), exercer de forma abusiva posição dominante (inc. IV). É do parágrafo $1^{\circ}$ do mesmo artigo que a conquista de mercado resultante de processo natural fundado na maior eficiência de agente econômico em relação a seus competidores não caracteriza o ilícito previsto no inc. II. No parágrafo $2^{\circ}$, ficou estabelecido que ocorre posição dominante quando uma empresa ou grupo de empresas controla parcela substancial de mercado relevante, como fornecedor, intermediário, adquirente ou financiador de um produto, serviço ou tecnologia a ele relativa - e no parágrafo $3^{\circ}$, na redação dada pela Lei ${ }^{\circ}$ 9.069, de 29 de junho de 1995, que a posição dominante a que se refere o parágrafo anterior é presumida quando a empresa ou grupo de empresas controla $20 \%$ (vinte por cento) de mercado relevante, podendo este percentual ser alterado pelo CADE para setores específicos da economia. Firme no seu propósito, no art. 21 o legislador decidiu de enumerar - de forma não exaustiva, como deixou registrado - as condutas que, na dependência de se ver configurada uma das hipóteses do art. 20, caracterizam infração da ordem econômica.

Examinados esses elementos, é recomendável frisar que o titular do bem jurídico protegido, a ordem econômica, é a Coletividade. Ora, informada a ordem econômica pela livre concorrência, desta também é titular a Coletividade. Por conseguinte, há de prevalecer o interesse da Coletividade nas situações de conflito nas quais enredada a livre concorrência.

Destaque-se, outrossim: 
a) a Lei sob exame diz com a regulamentação do mercado: não the interessam os concorrentes, mas sim a concorrência;

b) os "atos, sob qualquer forma manifestados" de que se cuida na cabeça do art. 20 englobam toda e qualquer conduta do agente econômico que tenha por objeto ou possa produzir um dos efeitos enumerados nos incisos do mesmo artigo, independentemente de ter, ou não, posição dominante no mercado;

c) a lei não exige que o "ato" produza efeito concreto no terreno da concorrência: é bastante, para caracterizá-lo como ilícito, que tenha potencial para gerar o efeito anticompetitivo;

d) as condutas enumeradas no art. 21, lista exemplificativa, não constituem ilícitos por si mesmas: é necessário, para dá-las como infrações, que tenham por objeto ou possam produzir um dos efeitos listados nos incisos do art. 20;

e) a responsabilidade pelas infrações é independente de culpa, i. e., a vontade do agente é irrelevante.

\subsection{A tributação e a livre concorrência}

Desde quando instituída, a tributação sempre teve como finalidade essencial a coleta de fundos necessários para o cumprimento das missões do Estado. Cuida-se da "função arrecadação", do emprego da tributação como fonte de receita pública.

Pretendia-se, até as primeiras décadas do Século XX, que a tributação fosse caracterizada por absoluta neutralidade. $\mathrm{O}$ tributo neutro teria por ambição não pesar sobre as escolhas dos sujeitados ao seu peso, escolhas estas que se determinariam em função de uma racionalidade econômica livre de influência de tal ou qual vantagem de cunho tributário.

Observou-se, mais adiante, que o Estado não alcançaria orientar determinados comportamentos sem que utilizasse a tributação como expediente. Mostrou-se necessário 
empregá-la como meio de "regulação conjuntural", manuseá-la como instrumento no combate à inflação, no estímulo das atividades econômicas e na busca do pleno emprego. A legislação tributária passou a contar com "normas indutoras", discriminações que são ofensas ao próprio dogma da neutralidade ${ }^{249}$. O certo é que, nas últimas décadas, as "políticas fiscais" sempre têm em grande conta as virtudes e os defeitos que supostamente comportam os diversos tipos de tributos frente à vida econômica. Assim é que certas políticas visarão a favorecer a procura, ou, inversamente, a oferta, enquanto outras tentarão encorajar tal ou qual setor de economia reduzindo a carga tributária relativa a determinadas hipóteses $^{250}$.

Forçoso reconhecer, no entanto, que a legislação tributária há de ser formulada e aplicada de modo a não prejudicar a livre concorrência, ou de modo a fomentá-la: sabendose que a República Federativa do Brasil constitui-se em Estado Democrático de Direito, cumpre ao Estado, quando da elaboração e da aplicação da norma tributária, observar o princípio da livre concorrência, consagrado que está no próprio texto constitucional. De outra banda, cabe aos agentes econômicos cumprir fielmente com seus deveres tributários, não dando ensejo, via de seu descumprimento, a que surjam desequilíbrios no mercado em que atuam, ou se agravem os porventura já existentes.

\subsection{O princípio da neutralidade concorrencial dos tributos}

Sabe-se que o princípio da igualdade obsta que se distinga entre contribuintes de situação econômica equivalente, coibindo a consideração da ocupação profissional ou da função exercida como critério para a concessão de favores ou privilégios, bem como para o agravamento de seus deveres tributários. Em decorrência do conteúdo do princípio da igualdade, mostra-se necessário que os tributos sejam aplicados com generalidade, isto é, abarcando integralmente as categorias de pessoas e bens previstas na lei - e não a uma

249 Cf. GROSClAUdE, Jacques; MARCHESSOU, Philippe. Droit Fiscal Général. 6. ed. Paris: Dalloz, 2007, p. 6.

250 Cf. BOUVIER, Michel. Introduction au Droit Fiscal Général et à la Théorie de l'Impôt. 8. ed. Paris: LGDJ, 2007, p. 165. 
parte delas $^{251}$. Cuida-se do que se conhece por princípio da generalidade da tributação, malgrado não passar de uma expressão do princípio de igualdade.

Observado que a neutralidade absoluta na imposição dos tributos não passa de mera $\operatorname{aspiração~}^{252}$ - e considerados os princípios da igualdade e da generalidade, é certo que nenhum esforço há de ser poupado para que tributação reste impedida de implicar a inobservância do princípio da livre concorrência. Diferentemente da neutralidade à que se fez referência linhas atrás, aqui se cuida do princípio da neutralidade concorrencial.

Manifestação de liberdade pública ${ }^{253}$, o princípio da neutralidade concorrencial visa a assegurar que o Estado se mantenha neutro, não tome partido, perante a competição levada a cabo pelos agentes econômicos que desenvolvam atividades lícitas em igualdade de condições. Almejando a igualdade de chances para os concorrentes, o princípio da neutralidade concorrencial visa a garantir que o Estado se abstenha de adotar "medidas que, ao privilegiar concorrentes em igualdade de condições, venham a prejudicar consumidores ou a criar desigualdades regionais ou a desfavorecer pequenas. empresas ou a proteger o meio ambiente, de um lado, para desprotegê-las de outro etc." 254

No que tange à tributação, o respeito devido ao princípio da neutralidade concorrencial equivale a uma verdadeira limitação ao poder de tributar: não se permite que o Estado, por meio da legislação tributária, venha a malferir a livre concorrência. Como ensina FERNANDO FACURY SCAFF ${ }^{255}$, o exercício da livre concorrência tem como requisito a observância do "Princípio da Neutralidade Econômica dos Tributos": é necessário que

251 Cf. FONROUGE, Carlos Giuliani. Derecho Financiero. v. 1. Atualização de Susana Camila Navarrine e Rubén Oscar Asorey. 6. ed. Buenos Aires: Depalma, 1997, p. 371.

252 A respeito do tema, têm sabor todo especial as seguintes palavras de Rubens Gomes de Sousa: "mesmo simplificando o assunto ao mínimo essencial, temos de partir de um pressuposto certo, isto é, temos de nos guardar da falácia de que existem impostos 'neutros', ou seja, impostos que geram receita sem produzir outros efeitos econômicos paralelos. Ora, que eu saiba, só Moisés tirou água de pedra, e isso mesmo porque Jeová deu uma mãozinha. Todo imposto é uma transferência de poder aquisitivo: de modo que aí já está o germe dos seus 'outros' efeitos econômicos. Sem falar numa porção de outras falácias que decorrem da primeira, como 'impostos diretos e indiretos', 'contribuinte legal e contribuinte econômico', 'parafiscalidade', etc., etc., etc.”. Cf. Os Impostos sobre o Valor Acrescido no Sistema Tributário. Revista de Direito Administrativo, Rio de Janeiro, n. 110, p. 17-26 (p. 20), out./dez. 1972.

253 Cf. GRAU, Eros Roberto. Princípio da Livre Concorrência - Função Regulamentar e Função Normativa. Revista Trimestral de Direito Público, São Paulo, v. 93, n. 4, p. 104-129 (p. 124), 1993.

254 Cf. FERRAZ JÚNIOR, Tercio Sampaio. Obrigação Tributária Acessória e Limites de Imposição: Razoabilldade e Neutralidade Concorrencial do Estado. In: FERRAZ, Roberto Catalano Botelho (Coord.). Princípios e Limites da Tributação. São Paulo: Quartier Latin, 2005, p. 715-735 (p. 732 ).

255 Cf. ICMS, Guerra Fiscal e Concorrência na Venda de Serviços Telefônicos Pré-Pagos. Revista Dialética de Direito Tributário, São Paulo, n. 126, p. 70-80 (p. 78), mar. 2006. 
"os tributos sejam economicamente neutros para que não venham a distorcer os preços praticados pelas empresas dentro de um mesmo mercado relevante".

Nesse sentido, vale transcrever a definição proposta por FRITZ NEUMARK ${ }^{256}$ ao "princípio da neutralidade fiscal ante a concorrência":

O princípio de evitar as conseqüências involuntárias dos prejuízos que os impostos ocasionam à concorrência requer que a política fiscal, no que se relaciona com a transferência coativa por ela originada dos recursos econômicos, ou da subtração à capacidade aquisitiva que esta transferência representa, se abstenha de toda intervenção que prejudique o mecanismo competitivo do mercado, a menos que a intervenção seja indispensável para provocar correções dos resultados da concorrência perfeita, as que por razões de ordem superior se considerem necessárias, ou para suprimir ou atenuar determinadas imperfeições da concorrência.

Encampada a definição, observa-se que o princípio é dotado de dois aspectos. No que prescreve ao Estado abster-se de provocar desarranjos na concorrência por meio de norma tributária, tem aspecto negativo. No que indica o emprego da norma tributária para fomentar a concorrência, tem aspecto positivo. Manejando-o com o fim de corrigir desequilíbrios já verificados no âmbito da concorrência, o Estado pratica uma intervenção negativa; empregando-o para fomentar a concorrência, pratica uma intervenção positiva.

\subsection{A livre concorrência como justificativa da norma tributária}

Largamente abordada no texto constitucional, a Ordem Tributária é informada por numerosos princípios, todos eles de observância necessária na elaboração e aplicação da norma tributária. O mesmo se dá com a Ordem Econômica: também a informam bom número de princípios, todos eles de observância necessária. Tais conjuntos não flutuam livres: cada um deles exerce influência sobre o outro, mostrando-se necessário que a atenção dada ao primeiro não implique a desatenção ao segundo - e vice-versa. Em outras palavras, a aplicação desses princípios não prescinde de ponderação. Por conseguinte, a elaboração de norma tributária que tenha como justificativa corrigir desarranjos verificados na concorrência, ou fomentá-la, não pode deixar ao relento os princípios da própria Ordem Tributária.

256 Cf. Principios de la Imposición. Madrid: Instituto de Estudios Fiscales, 1974, p. 321. 
Respeitado o princípio da igualdade, a elaboração de norma tributária que tenha a livre concorrência como justificativa não há de impor ônus tributários díspares a agentes econômicos que se encontrem em situação equivalente. Observado o princípio da capacidade contributiva, não há de exigir, a título de imposto, montantes que resultem na impossibilidade de tal ou qual competidor permanecer no mercado. Verificada a essencialidade do produto fabricado por agente que detém monopólio, não será por meio da alíquota do IPI que se corrigirá a situação, permitindo a entrada de concorrentes no mercado: o princípio da seletividade deverá ser respeitado, procurando-se avivar a concorrência por meio de outro expediente. São meros exemplos, pois como se disse há pouco, cada um dos princípios que informam a Ordem Tributária há de ser considerado na elaboração de norma tributária que se pretenda dar como justificada na livre concorrência.

Como ensina Luís EdUARDO SCHOUERI ${ }^{257}$, "a norma tributária fomentará a livre concorrência quando, por meio de estímulos, levar os agentes a práticas que incrementem o próprio mercado, ou melhor, a competição no mercado", sendo certo que "terá tal caráter a norma que agravar a tributação em mercados pouco competitivos, ou que reduzir a carga tributária de mercados cujo acesso seja irrestrito". A título de exemplo, cita a norma tributária que tenha por fim incentivar o pequeno empresário, norma esta cuja elaboração tem como fundamento de validade o quanto disposto no art. 179 da CF de $1988^{258}$. Amparadas nesse dispositivo, em proveito da concorrência vieram à luz (i) a Lei no 9.317, de 5 de dezembro de 1996, que, já revogada, dispunha sobre o regime tributário das microempresas e das empresas de pequeno porte, instituía o Sistema Integrado de Pagamento de Impostos e Contribuições das Microempresas e das Empresas de Pequeno Porte - SIMPLES, bem assim (ii) a Lei Complementar $n^{\circ}$ 123, de 14 de dezembro de 2006, que instituiu o Estatuto Nacional da Microempresa e da Empresa de Pequeno Porte e o regime de tributação conhecido por "Simples Nacional".

Cabe mencionar, por derradeiro, que o próprio Poder Constituinte Derivado pode lançar mão da livre concorrência como justificativa para emendar a Constituição Federal. Foi o que fez quando, na Emenda Constitucional no 33, de 11 de dezembro de 2001, alterou a redação do art. 155, § $2^{\circ}$, IX, "a", do texto constitucional original. Segundo estava de

257 Cf. Livre Concorrência e Tributação. In: ROCHA, Valdir de Oliveira (Coord.). Grandes Questões Atuais do Direito Tributário. São Paulo: Dialética, 2007, v. 11, p. 241-271 (p. 252-253).

258 Art. 179 - A União, os Estados, o Distrito Federal e os Municípios dispensarão às microempresas e às empresas de pequeno porte, assim definidas em lei, tratamento jurídico diferenciado, visando a incentivá-las pela simplificação de suas obrigações administrativas, tributárias, previdenciárias e creditícias, ou pela eliminação ou redução destas por meio de lei. 
início, o ICMS incidia "sobre a entrada de mercadoria importada do exterior, ainda quando se tratar de bem destinado a consumo ou ativo fixo do estabelecimento, assim como sobre serviço prestado no exterior, cabendo o imposto ao Estado onde estiver situado o estabelecimento destinatário da mercadoria ou do serviço". Interpretando o dispositivo, estabeleceu o STF que o ICMS não onerava a importação de bens levada a cabo (i) por pessoas físicas e (ii) pessoas jurídicas prestadoras de serviços outros que não os de transporte intermunicipal e interestadual e comunicação. Disso resultava que produtores e comerciantes brasileiros competissem em condições desfavoráveis frente aos produtores e comerciantes estabelecidos no estrangeiro, situação esta que se impunha corrigir. Foi o que se deu, ficando estabelecido, com a citada Emenda Constitucional, que o ICMS passaria a incidir "sobre a entrada de bem ou mercadoria importados do exterior por pessoa física ou jurídica, ainda que não seja contribuinte habitual do imposto, qualquer que seja a sua finalidade, assim como sobre o serviço prestado no exterior, cabendo o imposto ao Estado onde estiver situado o domicílio ou o estabelecimento do destinatário da mercadoria, bem ou serviço".

Os exemplos bem demonstram que, corretamente empregada, a livre concorrência pode justificar a norma tributária.

\subsection{Os reflexos do diferimento constante da legislação paulista do ICMS para o lado da concorrência. Conjecturas}

Como já se disse, a norma tributária não deve dar ensejo à inobservância do princípio da livre concorrência. Em outras palavras, a norma tributária há de ser limitada de modo a não se ver desobedecido o princípio da livre concorrência. Lamentavelmente, é frequente que se dê o contrário. Os exemplos são inúmeros. Vejamos, na sequência, o que pode resultar do emprego do diferimento do lançamento do ICMS nas terras paulistas.

A CT-SP, reportando-se à quantia a ser desembolsada pelo adquirente de mercadoria no âmbito de operação cuja tributação estava submetida ao diferimento do lançamento - quantia esta fixada pelos interessados no negócio sem que levado em conta o peso do tributo, por conseguinte -, cogitou sobre a existência de possível vantagem de cunho "financeiro" (sic) em favor do adquirente. Segundo está na Resposta à Consulta 
$\mathrm{n}^{\mathrm{o}} 4.757$, de 5 de julho de $1973^{259}$, "uma parcela do preço foi deslocada das etapas anteriores para a etapa subseqüente da circulação", o que "poderia" (sic) resultar, em prol do adquirente, numa "menor oneração de capital de giro na aquisição das mercadorias". A escolha do verbo poder não se mostrou a mais adequada: se o preço do negócio não inclui nada que diga com o imposto, é seguro que o capital de giro do adquirente será menos onerado do que se incluísse. Não é difícil conceber que, podendo adquirir tal ou qual mercadoria pelo preço "x", no qual nada incluído a título de imposto, dificilmente alguém optará por adquirir o mesmo bem pelo preço " $y$ ", sendo " $y$ " maior do que "x" porque em “y” englobado o montante do tributo.

Sabendo-se que o diferimento do lançamento da legislação paulista não pode irradiar efeitos para a banda de operações interestaduais - nenhum Convênio ICMS e nenhum Protocolo ICMS está a permitir o contrário - a remessa de mercadoria de outras Unidades da Federação para destinatário paulista necessariamente será onerada pelo ICMS.

Ora, se as operações relativas à circulação de tal ou qual mercadoria têm sua tributação regrada pelo diferimento do lançamento tão somente quando levadas a cabo nos limites do território de São Paulo, não englobado o montante do imposto no preço do negócio - e se as operações interestaduais concernentes à mesma mercadoria não se submetem ao mesmo diferimento, conseguintemente incluído o montante do imposto no preço do negócio, é incensurável afirmar que, salvo situações excepcionais, os negócios transcorridos exclusivamente nas terras paulistas se darão por preços inferiores àqueles dos negócios interestaduais. Claro está que as condições do mercado podem infirmar o raciocínio, mas o certo é que o vendedor paranaense, por exemplo, jamais estará competindo em condições de igualdade com o vendedor paulista. Enfim, parece clara a lesão ao princípio da livre concorrência.

Alguém poderá argumentar que o exame do quadro descrito não revela nenhuma ofensa ao princípio da não discriminação de que se cuida no art. $152^{260}$ da CF de 1988 , firme no entendimento de que os limites da competência do Estado de São Paulo para legislar acerca do ICMS não foram ultrapassados - e vedada sua ingerência, por força do princípio federativo, no campo da legislação que, instituída pelas demais Unidades da

259 Cf. LARANJEIRA, Álvaro Reis (Org.). ICM: Respostas da Consultoria Tributária. São Paulo: LTr, 1978, p. 54.

260 Art. 152 - É vedado aos Estados, ao Distrito Federal e aos Municípios estabelecer diferença tributária entre bens e serviços, de qualquer natureza, em razão de sua procedência ou destino. 
Federação, exige de seus sujeitados o pagamento de ICMS quando da remessa de mercadoria para as terras paulistas. A objeção, se examinada tão somente a Ordem Constitucional Tributária, mereceria apreço. Sucede, vale insistir, que é de ser igualmente observada a Ordem Econômica cuidadosamente traçada pela CF de 1988. Se o Estado de São Paulo tem competência para instituir o ICMS e disciplinar sua imposição, é seguro que nenhuma política fiscal, como registra GERD WILLI ROTHMANN, "deve intervir na economia de mercado, de modo a prejudicar o seu mecanismo concorrencial", a não ser quando necessário "para eliminar ou mitigar imperfeições da livre concorrência, mediante o aumento da competitividade das empresas de determinados setores da economia ou regiões do país" ${ }^{261}$, do que não se trata em relação ao diferimento do lançamento do ICMS, dado pela própria CT-SP, como simples "medida adotada no interesse do Erário, com o fito de simplificar o controle da arrecadação e a fiscalização do pagamento do imposto"262.

Ainda que a objeção de que se cogitou logo acima fosse procedente, o que se admite tão só para argumentar, de nada valeria frente a umas tantas outras regras do diferimento do lançamento engendrado pelo Estado de São Paulo, regras estas cujo exame descortina ofensas frontais ao princípio da não-discriminação do art. 152 da CF de 1988. Tal é o caso das que dizem com operações relativas à circulação de algodão em caroço (RICMS/00, art. 329), algodão em pluma ou caroço de algodão, resultantes do beneficiamento de algodão em caroço (RICMS/00, art. 330), cana-de-açúcar em caule (RICMS/00, art. 345) e mamona em cacho, em baga, ou em grão (RICMS/00, art. 350, I). É que previsto o princípio da clareza única e exclusivamente para as operações nas quais compreendida mercadoria de produção paulista. Vale dizer: em se tratando de operações internas, a circulação de mercadoria de produção paulista sofrerá tratamento diverso daquela aplicado à circulação de mercadoria proveniente de outras Unidades da Federação. Em desfavor das últimas, é seguro afirmar.

Os exemplos trazidos à balha logo acima bem demonstram que o Poder Executivo paulista, ao manejar normas tributárias gerais e abstratas, nem sempre se dá ao trabalho de

261 Cf. A Guerra Fiscal dos Estados na (Des)Ordem Tributária e Econômica da Federação. In: CARVALHO, Antonio Augusto Silva Pereira de; FERNÁNDEZ, German Alejandro San Martín (Coord.). Estudos em Homenagem a José Eduardo Monteiro de Barros - Direito Tributário. São Paulo: MP, 2010, p. 333-355 (p. 335). O A. expressa o mesmo entendimento em Tributação, Sonegação e Livre Concorrência. In: FERRAZ, Roberto (Coord.). Princípios e Limites da Tributação 2 - Os Princípios da Ordem Econômica e a Tributação. São Paulo: Quartier Latin, 2009, p. 331-371 (p. 341).

262 Mencionamos, aqui, a resposta à consulta $n^{\circ} 11.792$, de 24 de abril de 1978 , já abordada no tópico "6."deste trabalho. 
homenagear (i) o princípio da livre concorrência e (ii) o princípio da não-discriminação consagrado no art. 152 da CF de 1988.

O quadro assume ar mais grave quando se lança mão do diferimento do lançamento com o propósito de conferir benefício fiscal, ainda que seja de forma oblíqua. É o tema que logo adiante cuidaremos de examinar. 


\section{O DIFERIMENTO E SEU CONTROVERSO CARÁTER DE BENEFÍCIO FISCAL}

Determina a CF de 1988, no seu art. 155, XII, "g", que cabe à lei complementar "regular a forma como, mediante deliberação dos Estados e do Distrito Federal, isenções, incentivos e benefícios fiscais serão concedidos e revogados" ${ }^{, 263}$.

Pois bem: visto que o Constituinte de 1988 empregou os termos "incentivos" e "benefícios" ligados pela conjunção “e”, parece necessário, à primeira vista, que não os empreguemos um no lugar do outro, que não lhes atribuamos o mesmo significado. Assim recomenda CELSO RIBEIRO BASTOS: na interpretação da Constituição, “a termos diferentes não se deve atribuir o mesmo significado, salvo em casos excepcionais, devidamente motivados" ${ }^{264}$. O A. parte da premissa de que, no corpo da Constituição, sinonímias não deveriam existir, o que, assinala, nem sempre ocorre ${ }^{265}$.

Marcelo de Lima Castro Diniz e Fellipe CianCa Fortes mostram-se seguros: não se admite o uso de "incentivo fiscal" e "benefício fiscal" como sinônimos. Sustentam que "incentivos fiscais" são os que, (i) alcançando as obrigações tributárias, alteram ou mutilam a regra-matriz de incidência, acarretando redução da prestação tributária, (ii) têm por alvo o "fomento geral, regional ou setorial, em busca do bem comum", e (iii) exigem, por conta de quem deles tira vantagem, "contrapartida diretamente vinculada à promoção do bem comum" 266 . O traço que os distingue dos "benefícios fiscais" é que, nestes, não se exige a mencionada contrapartida, o que os caracteriza como privilégios conferidos diretamente a quem deles se aproveita ${ }^{267}$.

\footnotetext{
263 Recepcionada pela CF de 1988, é a LC no 24/75 o diploma que para tanto serve.

264 Cf. Hermenêutica e Interpretação Constitucional. São Paulo: Celso Bastos/Instituto Brasileiro de Direito Constitucional, 1997, p. 117.

265 Idem, ibidem.

266 Cf. Incentivos Fiscais no STJ. In: MARTINS, Ives Gandra da Silva; ELALI, André; PEIXOTO, Marcelo Magalhães (Coords.). Incentivos Fiscais: Questões Pontuais nas Esferas Federal, Estadual e Municipal. São Paulo: MP, 2007, p. 265-297 (p. 271-275).

Idem, ibidem.
} 
JosÉ SOUTO MAIOR BORGES pensa de modo algo diverso. Afirma que a redação do art. 155, XII, "g", da CF de 1988 está contaminada de pleonasmo, pois "todo 'benefício fiscal' acaba por confundir-se com um 'incentivo" 268 .

Por sua vez, RiCARDo LOBO TORRES anota que os termos "incentivo", "estímulo" e "prêmio", empregados indistintamente pela própria legislação ordinária brasileira, "não possuem significado jurídico claro"269. O entendimento é compartilhado por ELCIO FIORI HENRIQUES. Segundo o A., as expressões "benefícios fiscais", "incentivos fiscais", “desoneração tributária", "isenções", "privilégios fiscais" e "alívio fiscal” são empregadas na doutrina e na legislação como expressão de um mesmo conceito ${ }^{270}$ - e opta por adotar "benefício fiscal" como a mais proveitosa, do que dá conta o próprio título da sua obra. Revela, no entanto, que ainda não se deu ao conceito de "benefício fiscal" nenhuma definição satisfatória, mas que "característica fundamental desse conceito é que tais normas determinam, por meio de uma grande variedade de mecanismos, um tratamento tributário menos gravoso para os contribuintes beneficiados, acarretando um recolhimento menor de tributos" 271 .

Não nos deteremos em examinar o tema com maior profundidade. Para os fins deste trabalho é bastante adotar a lição de ELCIO FIORI HENRIQUES, o que nos permite empregar, com tranquilidade, a expressão "benefício fiscal"

Tendo em mente esses breves notas, passemos a examinar manifestações que dizem respeito à caracterização do diferimento como espécie de benefício fiscal, ou não, gizando desde logo que a respeito do tema não há entendimento uniforme.

\subsection{Primeira inteligência: não se cuida de benefício fiscal}

IVES GANDRA DA Silva MARTINS registrou - texto publicado em 1983 - que o diferimento se traduz por "mera adoção de técnica arrecadatória que não visa beneficiar o

268 Cf. Sobre as Isenções, Incentivos e Benefícios Fiscais Relativos ao ICMS. Revista Dialética de Direito Tributário, São Paulo, n. 6, p. 69-73 (p. 69), 1996.

269 Cf. Conflitos de Competência e Guerra Fiscal. In: Congresso Nacional de Estudos Tributários (5: 2008: São Paulo, SP) Direito Tributário Linguagem e Método. São Paulo: Noeses, 2008, p. 825-847 (p. 827).

270 Cf. Os Benefícios Fiscais no Direito Financeiro e Orçamentário. São Paulo: Quartier Latin, 2010, p. 28.

271 Idem, ibidem. 
sujeito passivo da relação tributária, mas simplificar a fórmula de recebimento do I.C.M. pelo sujeito ativo da referida relação"272.

Para Sacha Calmon Navarro CoÊlho, o diferimento é técnica de tributação estribada no feitio polifásico do ICM - texto publicado em 1982 - e não se confunde com nenhum tipo de "benefício fiscal"273

Também entende assim José RoBerto RosA. Segundo o A., "o diferimento não se caracteriza como benefício fiscal, não necessitando de lei ordinária ou de convênio do Confaz" $^{, 274}$.

Na pesquisa da qual resultou este trabalho não se encontrou nenhuma decisão que, proferida pelo STF, registrasse expressamente que o diferimento, no âmbito do ICM, ou do ICMS, devesse ser considerado como benefício fiscal, ou não. Sucede que, por via oblíqua, a Corte estabeleceu que de benefício fiscal não se trata, pois fixou que desnecessária a celebração de convênio estadual para sua implantação. A título de exemplo, vejamos as ementas $^{275}$ que, por nós acrescentadas de grifo, têm o seguinte teor:

Recurso extraordinário. ICM. Creditamento do valor do ICM diferido, na entrada de soja em grão, para o momento da saída do produto industrializado. Distinção entre diferimento e isenção. Do diferimento não resulta eliminação ou redução do ICM; o recolhimento do tributo é que fica transferido para momento subsequente. Não há ofensa ao princípio da nãocumulatividade do ICM na pratica de seu diferimento. Precedentes do STF. Inviável e a pretensão das impetrantes de creditar-se do ICM, nas operações de compra e venda de soja. Não se faz necessária a celebração de convênio, pelo Estado, em torno de diferimento, tal como sucede com a isenção. Recurso extraordinário não conhecido. (RE 112098, Relator: Min. Néri da Silveira, Primeira Turma, julgado em 10/06/1988, DJ 14-02-1992 pp-01167 Ement vol-01649-02 pp-00388 RTJ vol-00137-03 pp-01323)

Ação Direta de Inconstitucionalidade. Artigos $9^{\circ}$ a 11 e 22 da Lei n. 1.963, de 1999, do Estado do Mato Grosso do Sul. 2. Criação do Fundo de Desenvolvimento do Sistema Rodoviário do Estado de Mato Grosso do Sul - FUNDERSUL. Diferimento do ICMS em operações internas com produtos agropecuários. 3. A contribuição criada pela lei estadual não possui natureza tributária, pois está despida do elemento essencial da compulsoriedade.

272 Cf. A Técnica de Diferimento da Incidência do ICM - Constitucionalidade do Princípio da Não Cumulatividade Quando de sua Adoção. Revista da Procuradoria Geral do Estado de São Paulo. São Paulo, n. 21, p. 169-197 (p. 185), dez. 1983.

273 Cf. A Natureza Jurídica do Diferimento na Área do ICM. Revista de Direito Tributário, São Paulo, n. 21/22, p. 5-41 (p. 26-27), jul./dez. 1982.

274 Cf. Curso de ICMS com o Professor José Rosa. Itu (SP): Ottoni, 2008. p. 105; Substituição Tributária no ICMS: Manual Explicativo. 2. ed. Itu: Ottoni, 2009, p.11.

275 Disponíveis em <http://www.stf.jus.br/portal/principal/principal.asp>. Acesso em 14 set 2009. 
Assim, não se submete aos limites constitucionais ao poder de tributar. 4. $O$ diferimento, pelo qual se transfere o momento do recolhimento do tributo cujo fato gerador já ocorreu, não pode ser confundido com a isenção ou com a imunidade e, dessa forma, pode ser disciplinado por lei estadual sem a prévia celebração de convênio. 5. Precedentes. 6. Ação que se julga improcedente. (ADI 2056, Relator: Min. Gilmar Mendes, Tribunal Pleno, julgado em 30/05/2007, DJe-082 divulg 16-08-2007 public 17-08-2007 DJ 17-08-2007 pp-00022 Ement vol-02285-02 pp-00365 RTFP v. 15, n. 76, 2007, p 331-337)

No tocante à CT-SP, seguro que afirmou, por mais de uma vez, que o diferimento do lançamento de que se cuida na legislação paulista não traduz nenhuma espécie de benefício fiscal. Vejamos.

Extrai-se da Resposta à Consulta $n^{\circ} 11.792$, de 24 de abril de 1978 - na época do ICM, portanto -, que o diferimento "não é benefício fiscal”, pois "não retira as operações do campo da incidência do imposto; apenas transfere para etapa futura da circulação o momento do lançamento tributário", não passando de "medida adotada no interesse do Erário, com o fito de simplificar o controle da arrecadação e a fiscalização do pagamento do imposto" 276 . O mesmo entendimento foi expressado quanto ao diferimento do lançamento constante da legislação do ICMS: na Respostas à Consulta nº 533/05, de 23 de setembro de 2005, escreveu que "o diferimento no lançamento do ICMS não se trata de benefício fiscal (...), mas sim de postergação do lançamento do imposto, com transferência da responsabilidade para outro contribuinte nas hipóteses previstas na legislação tributária",277.

É bem verdade que, tendo em mente a quantia a ser desembolsada pelo adquirente de mercadoria no âmbito de operação cuja tributação estava submetida ao regime - quantia esta fixada pelos interessados no negócio sem que levado em conta o peso do tributo, por conseguinte -, cogitou sobre a existência de possível vantagem de cunho "financeiro" em favor do adquirente. É que, segundo está na Resposta à Consulta $\mathrm{n}^{\circ} 4.757$, de 5 de julho de 1973, "uma parcela do preço foi deslocada das etapas anteriores para a etapa subseqüente da circulação", o que poderia resultar, em prol do adquirente, numa "menor oneração de capital de giro na aquisição das mercadorias" 278 .

276 Cf. LARANJEIRA, Álvaro Reis (Org.). ICM: Respostas da Consultoria Tributária. v. 2. São Paulo: LTr, 1984, p. 164.

277 Cf. SECRETARIA DE ESTADO DOS NEGÓCIOS DA FAZENDA - Coordenadoria da Administração Tributária. Boletim Tributário, São Paulo, n. 6, p. 419-420 (p. 419), jul 2006.

278 Cf. LARANJEIRA, Álvaro Reis (Org.). ICM: Respostas da Consultoria Tributária. São Paulo: LTr, 1978, p. 54. 
É bem verdade, outrossim, que na Resposta à Consulta $n^{\circ}$ 9.750, de 15 de julho de $1976^{279}$, referindo-se a aquisição de "soja em grão com diferimento do imposto", o órgão consultivo registrou que "o adquirente torna-se o contribuinte substituto do tributo, de imediato beneficiado com o favor fiscal, refletido na diminuição do preço das mercadorias adquiridas, assumindo, evidentemente, a obrigação do pagamento do imposto" (g. n.).

\subsection{Segunda inteligência: cuida-se de benefício fiscal}

RICARDO LOBO TORRES enquadra expressamente o diferimento, na área do ICMS, como espécie de "benefício tributário"280.

Outro não é o entendimento de Roque Antonio CARrazza. Segundo o A., o diferimento é "um tipo de benefício fiscal, que, em matéria de ICMS, deve obedecer às mesmas diretrizes que norteiam a concessão de créditos presumidos, isenções etc."281.

RAFHAEL FRATTARI é categórico quanto a tratar-se o diferimento de benefício fiscal. Afirma: “óbvio ululante que o diferimento é uma técnica arrecadatória, mas nem por isso deixa de ter efeitos fiscais contundentes na vida econômica dos que dele aproveitam$\mathrm{se}^{, 282}$.

Filiam-se ao mesmo pensar, atribuindo ao diferimento o caráter de benefício fiscal, AdILSON RODRIGUES PIRES ${ }^{283}$, GUSTAVO F. CAVALCANTI COSTA ${ }^{284} \mathrm{e}$ todos os estudiosos que o veem como espécie de isenção, por óbvio, dentre os quais já citamos, no tópico "3.2" deste trabalho, Clélio Chiesa, Aurélio Pitanga SeiXas Filho, Edgard Neves Da Silva e Marcello Martins Motta Filho.

279 Cf. LARANJEIRA, Álvaro Reis (Org.). ICM: Respostas da Consultoria Tributária. v. 2. São Paulo: LTr, 1984, p. 28.

280 Cf. Conflitos de Competência e Guerra Fiscal. In: Congresso Nacional de Estudos Tributários (5: 2008: São Paulo, SP) Direito Tributário Linguagem e Método. São Paulo: Noeses, 2008, p. 825-847 (p. 842); O Princípio da Isonomia, os Incentivos do ICMS e a Jurisprudência do STF sobre a Guerra Fiscal. In: MARTINS, Ives Gandra da Silva; ELALI, André; PEIXOTO, Marcelo Magalhães (Coords.) Incentivos Fiscais: Questões Pontuais nas Esferas Federal, Estadual e Municipal. São Paulo: MP, 2007, p 327-345 (p. 341).

281 Cf. ICMS. 14. ed. São Paulo: Malheiros, 2009, p. 408.

282 Cf. O Diferimento e a Regra do Artigo $8^{\circ}$, Conjugado com o Item 39, Anexo II, do Regulamento Mineiro do ICMS/96. Eficaz Boletim Tributário, Belo Horizonte, n. 39, p. 2-6 (p. 4), 1998.

283 Cf. Ligeiras Reflexões Sobre a Questão dos Incentivos Fiscais no Brasil. In: MARTINS, Ives Gandra da Silva; ELALI, André; PEIXOTO, Marcelo Magalhães (Coords.). Incentivos Fiscais: Questões Pontuais nas Esferas Federal, Estadual e Municipal. São Paulo: MP, 2007, p. 15-35 (23-24).

284 Cf. O Conflito de Competência Exonerativa em Matéria de ICMS: uma Abordagem Político-Jurídica sobre a "Guerra Fiscal" na Federação Brasileira. Revista Tributária e de Finanças Públicas, São Paulo, n. 42 , p. $85-99$ (p. 90), jan./fev. 2002 
Vale registrar, ainda, o entendimento de JosÉ EdUARdo SOARES DE MELO e LUIZ FRANCISCO LIPPO. Malgrado não se utilizem das expressões "benefício fiscal" e "incentivo fiscal", os AA. afirmam que "no caso de diferimento, o que se verifica é uma espécie de extrafiscalidade que beneficia microempresas, como sucateiros e produtores de gêneros de necessidades básicas" e, "nesta circunstância, possui conteúdo manifestamente socioeconômico",285.

\subsection{O efetivo emprego do diferimento com o propósito de conferir benefício fiscal}

Considerada a divergência que viemos de abordar em rápidas notas, interessa examinar a legislação paulista do ICMS para verificar se é observável, ou não, o emprego do diferimento do lançamento com o propósito de conceder benefício fiscal, ou incentivo fiscal, como se queira. É o que passamos a fazer.

\subsubsection{Revisita às operações com "máquina ou implemento agrícola"}

Tornemos ao Decreto $n^{\circ} 51.608$, de 26 de fevereiro de $2007^{286}$. Como vimos, foi baixado para assentar que "nas sucessivas saídas internas de máquina ou implemento agrícola, o lançamento do ICMS incidente fica diferido para o momento em que ocorrer a saída, do estabelecimento rural, dos produtos resultantes sujeitos ao imposto", tal como está no seu art. $1^{\circ}$.

Pois bem: consta do Ofício GS n ${ }^{\circ}$ 90/2007 287 , por meio do qual o Titular da Pasta da Fazenda apresentou a minuta do Decreto ao Governador do Estado, que a medida "visa “à ampliação de investimentos e à oferta de empregos”.

Ora, examinados o Decreto e a minuta que lhe deu sustentação, necessário concluir que o Poder Executivo teve em mente conceder vantagem de cunho fiscal a estabelecimentos rurais, pouco importa o nome que se lhe dê, se incentivo, se benefício.

285 Cf. A Não-Cumulatividade Tributária (ICMS, IPI, ISS, PIS e COFINS). 3. ed. São Paulo: Dialética, 2008, p. 166.

286 Vide tópico "5.3." deste trabalho.

287 Reproduz-se, da minuta, o trecho que vem ao caso: “A medida (...) Visa à ampliação de investimentos e à oferta de empregos e observa o disposto na Lei Complementar ${ }^{\circ} 101$, de 2000, conhecida como "Lei de Responsabilidade Fiscal", uma vez que se trata de norma que se encontrava vigente até 31 de janeiro de 2007 e, desse modo, já considerada para os efeitos da citada Lei Complementar". 


\subsubsection{Revisita às operações com "insumos e produtos acabados da indústria de processamento eletrônico de dados"}

Como observamos no tópico "5.2.3" deste trabalho, o art. 396 do RICMS/00 dizia com diferimento do lançamento do imposto "incidente na saída interna promovida pelo estabelecimento fabricante de partes, peças, componentes, matérias-primas e materiais de embalagem com destino a estabelecimento fabricante da indústria de processamento eletrônico de dados abrangido pelo artigo $4^{\circ}$ da Lei federal $\mathrm{n}^{\circ} 8.248$, de 23 de outubro de 1991, para serem utilizados na fabricação de produto da referida indústria". O quanto transcrevemos no mencionado tópico não corresponde à versão original do artigo, mas aquela resultante da alteração promovida pelo Decreto ${ }^{\circ} 51.011$, de 28 de julho de 2006.

Pois bem: constou do Ofício GS no 326/2006 288 , por meio do qual o Titular da Pasta da Fazenda apresentou a minuta do que veio a ser o Decreto $n^{\circ}$ 51.011/06 ao Governador do Estado, que a medida tinha como objetivo, dentre outros, "garantir a competitividade da indústria de informática paulista frente a suas concorrentes de outras Unidades federadas".

Reavivemos a memória: o art. 396 do RICMS/00 foi revogado pelo inc. II do artigo

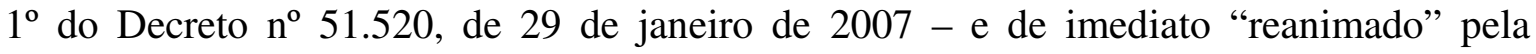
Portaria CAT n ${ }^{\circ} 14 / 07$.

Ora, não é demais acreditar que o objetivo visado pelo Poder Executivo, tanto ao prever o que constava da segunda feição do art. 396 do RICMS/00, quanto o que consta da referida Portaria, fosse o mesmo. Examinados o Decreto $n^{\circ} 51.011 / 06$ e Portaria CAT no 14/07, parece-nos legítimo concluir que o Poder Executivo teve em mente conceder privilégio de cunho tributário a "fabricante da indústria de processamento eletrônico de dados", pouco importa o nome que se lhe dê, se incentivo, se benefício.

288 Reproduz-se, da minuta, o trecho que vem ao caso: "A medida tem como objetivo aperfeiçoar o tratamento tributário das operações com insumos para a fabricação de produto da indústria de processamento eletrônico de dados, de modo a criar condições objetivas para a aplicação de diferimento ou suspensão do imposto devido na aquisição de insumos, garantir a competitividade da indústria de informática paulista frente a suas concorrentes de outras Unidades federadas e aprimorar os controles fiscais para evitar a ocorrência de fraudes ou utilização indevida do tratamento tributário". 


\subsubsection{Operações relativas à circulação de equinos de raça}

No seu art. $388^{289}$, o RICMS/00 dispõe sobre "operações com eqüinos de raça". Considerado o que logo adiante se pretende trazer à balha, limitemo-nos a examinar, do seu amplo texto, a cabeça e seus incisos. Deixar de banda o exame do restante do dispositivo não trará nenhum prejuízo ao desenvolvimento do tema.

Pois bem: estabeleceu-se, na cabeça do artigo, que "na circulação de eqüino, de qualquer raça, que tenha controle genealógico oficial e idade superior a 3 (três) anos", o imposto "será pago uma única vez", fixado para tanto o momento no qual se concretizar, por primeiro, uma das hipóteses listadas nos seus incisos, quais sejam: o "recebimento, pelo importador, de eqüino importado do exterior" (inc. I), o "ato de arrematação em leilão do animal” (inc. II), o “registro da primeira transmissão da propriedade no 'Stud Book' da raça" 290 (inc. III), a "saída para fora do Estado" (inc. IV).

O exame das regras enfeixadas nesses dispositivos dá causa a perplexidades de difícil - arrisca-se a dizer impossível - superação. Se não, vejamos.

Malgrado incluída no Capítulo que o RICMS/00 dedicou ao "diferimento do lançamento do imposto", observa-se, logo de início, que a disposição do art. 388, inc. I, sofre de marcante distopia: não se nota, no seu corpo, nada que diga respeito a diferimento do lançamento do ICMS. Em nenhuma passagem está registrado que o lançamento do imposto será postergado para momento posterior àquele no qual concretizada a importação do animal, nem que caberá a pessoa diversa do importador, numa subsequente operação, proceder ao lançamento do imposto devido em decorrência da importação.

Mais: é certo que o texto do inc. I não pode ser examinado sem que se preste a devida atenção àquele da cabeça do artigo, no qual está escrito que o ICMS “será pago

289 Artigo 388 - O imposto devido na circulação de eqüino, de qualquer raça, que tenha controle genealógico oficial e idade superior a 3 (três) anos, será pago uma única vez em um dos seguintes momentos, o que ocorrer primeiro (Lei 6.374/89, arts. 9, IV, 24, I e IV, 30 e Ajuste SINIEF-5/87, cláusula primeira, com alteração do Ajuste SINIEF-5/98):

I - no recebimento, pelo importador, de eqüino importado do exterior;

II - no ato de arrematação em leilão do animal;

III - no registro da primeira transmissão da propriedade no "Stud Book" da raça;

IV - na saída para fora do Estado.

290 Livro destinado a registrar, em resumo, dados referentes à genealogia dos animais, à sua identidade e à sua propriedade. Veja-se, a título de exemplo, o Regulamento da Associação Brasileira de Criadores e Proprietários do Cavalo de Corrida - Stud Book Brasileiro, disponível em <http://www. studbook.com.br/>. 
uma única vez". Vai daí que, no caso de importação de "eqüino, de qualquer raça, que tenha controle genealógico oficial e idade superior a 3 (três) anos", o que está previsto no RICMS/00 é que o imposto será pago tão somente quando concretizada a importação, ficando livres do tributo as eventuais operações comerciais que, levadas a efeito no território paulista, lhe forem posteriores.

No que diz respeito às hipóteses versadas nos demais incisos, não sofrem da mesma distopia - e mostram-se ajustadas ao figurino do diferimento do lançamento tal como desenhado pelo RICMS/00. Com efeito, verificando-se a ocorrência de sucessivas operações relativas à circulação dos animais discriminados na cabeça do art. 388, nada obsta a que se proceda ao lançamento do ICMS nos momentos neles fixados, tal como expressamente previsto.

Sucede que o quanto observado logo acima a respeito do inc. I também vale para os incisos II e III, com as necessárias adaptações. Determinando-se que o ICMS "será pago uma única vez", isto no "momento" em que o animal for objeto de "arrematação em leilão", as eventuais operações comerciais subsequentes levadas a efeito no território paulista estarão abrigadas do tributo. Do mesmo modo: estabelecido que o ICMS "será pago uma única vez", isto no "momento" em que se der o "registro da primeira transmissão da propriedade no 'Stud Book' da raça", as operações subsequentes levadas a efeito no território paulista estarão desoneradas do imposto.

Em resumo: desde que se concretize qualquer uma das hipóteses listadas nos incisos I, II e III, o ICMS “será pago uma única vez” e nada mais será devido por ninguém a título de ICMS caso venha a fazer, do animal, objeto de comércio no território paulista, pouco importando que, no decorrer do tempo, passe pela mão de "n" agentes econômicos dedicados ao comércio de "eqüinos de raça" - e que seu valor de mercado venha a aumentar no curso das sucessivas operações.

Ora bem: malgrado não se encontre o termo "isenção" no texto do Convênio ICMS 136/93 ${ }^{291}$, no qual inspirado o art. 388 do RICMS/00, o que se diagnostica é que o

291 CONVÊNIO ICMS 136/93

Publicado no DOU de 17.12.93.

Ratificação Nacional DOU de 04.01.94 pelo Ato COTEPE-ICMS 01/94.

Estabelece regime especial de tributação para as operações com eqüinos de raça.

O Ministro de Estado da Fazenda e os Secretários de Fazenda, Economia ou Finanças dos Estados e do

Distrito Federal, na $72^{\mathrm{a}}$ Reunião Ordinária do Conselho Nacional de Política Fazendária, realizada em 
CONFAZ entendeu de conceder tal benefício: ao depois da primeira operação, esta onerada pelo ICMS, nas subsequentes é de isenção que se trata.

Vale acrescentar que no Anexo I do RICMS/00, no qual listadas pelo Executivo paulista as hipóteses de isenção, não há nada que diga respeito a operações nas quais compreendidos equinos de raça, omissão que finda por tornar pouco fácil o reconhecimento de que existe o benefício, seja por parte das pessoas que dele podem tirar

Brasília, DF, no dia 9 de dezembro de 1993, tendo em vista o disposto na Lei Complementar $\mathrm{n}^{\circ} 24$, de 7 de janeiro de 1975, resolvem celebrar o seguinte

CONVÊNIO

Cláusula primeira $\mathrm{O}$ imposto devido na circulação de eqüino de qualquer raça, que tenha controle genealógico oficial e idade superior a 3 (três) anos será pago uma única vez em um dos seguintes momentos, o que ocorrer primeiro:

I - no recebimento, pelo importador, de equino importado do exterior;

II - no ato de arrematação em leilão do animal;

III - no registro da primeira transferência da propriedade no "Stud Book" da raça;

IV - na saída para outra unidade da Federação.

$\S 1^{\circ}$ A base de cálculo do imposto é o valor da operação.

$\S 2^{\circ} \mathrm{Na}$ hipótese do inciso II, o imposto será arrecadado e pago pelo leiloeiro.

$\S 3^{\circ}$ Nas saídas para outra unidade da Federação, quando inexistir o valor de que trata o $\S 1^{\circ}$, da base de cálculo do imposto será aquela fixada em pauta.

$\S 4^{\circ} \mathrm{O}$ imposto será pago através de guia de recolhimento específica, da qual constarão todos os elementos necessários à identificação do animal.

$\S 5^{\circ}$ Por ocasião do recolhimento do tributo, o imposto que eventualmente tenha sido pago em operação anterior, será abatido do montante a recolher.

$\S 6^{\circ} \mathrm{O}$ animal em seu transporte deverá estar sempre acompanhado da guia de recolhimento do imposto e do Certificado de Registro Definitivo ou Provisório, permitida fotocópia autenticada por cartório, admitida a substituição do certificado pelo Cartão ou Passaporte de Identificação fornecido pelo "Stud Book" da raça que deverá conter o nome, a idade, a filiação e demais características do animal, além do número de registro no "Stud Book".

$\S 7^{\circ} \mathrm{O}$ animal com mais de 3 (três) anos de idade, cujo imposto ainda não tenha sido pago por não ter ocorrido nenhum dos momentos previstos nos incisos desta cláusula, poderá circular acompanhado apenas do Certificado de Registro Definitivo ou Provisório, fornecido pelo "Stud Book" da raça, desde que o certificado contenha todos os dados que permitam a plena identificação do animal, permitida fotocópia autenticada por cartório, válida por 6 (seis) meses.

$\S 8^{\circ} \mathrm{Na}$ saída do eqüino de que trata esta cláusula para outra unidade da Federação, para cobertura ou para participação em provas ou para treinamento, e cujo imposto ainda não tenha sido pago, fica suspenso o recolhimento do imposto, desde que emitida a nota fiscal respectiva e o retorno do animal ocorra dentro do prazo de 60 (sessenta) dias, prorrogável, uma única vez, por período igual ou menor, a critério da repartição fiscal a que estiver vinculado o remetente.

$\S 9^{\circ}$ Para fins de transporte do animal, a guia de recolhimento do imposto referida no $\S 6^{\circ}$ poderá ser substituída por termo lavrado pelo fisco, da unidade da Federação em que ocorreu o recolhimento ou daquela em que o animal está registrado, no Certificado de Registro Definitivo ou Provisório ou no Cartão ou Passaporte de Identificação fornecido pelo "Stud Book", em que constem os dados relativos à guia de recolhimento. (Acrescido pelo Conv. ICMS 80/03, com efeito a partir de 03.11.03).

Cláusula segunda $\mathrm{O}$ eqüino de qualquer raça que tenha controle genealógico oficial e idade de até 3 (três) anos poderá circular, nas operações internas, acompanhado apenas do Certificado de Registro Definitivo ou Provisório, fornecido pelo "Stud Book" da raça, permitida fotocópia autenticada, desde que o certificado contenha todos os dados que permitam a plena identificação do animal.

Cláusula terceira As operações interestaduais como animal a que se refere a cláusula anterior ficam sujeitas ao regime normal de pagamento do ICMS.

Cláusula quarta $\mathrm{O}$ proprietário ou possuidor do eqüino registrado que observar as disposições das cláusulas primeira e segunda fica dispensado da emissão de nota fiscal para acompanhar o animal em trânsito.

Cláusula quinta Este Convênio entra em vigor na data da publicação de sua ratificação nacional. 
proveito, seja por parte de quem se ocupe de verificar a legitimidade e os reflexos das isenções concedidas pelo Estado. 


\section{CONCLUSÕES}

Como registramos logo no início deste trabalho, não nos moveu a ambição de ofertar respostas definitivas, mas o modesto objetivo de veicular conjecturas. A nota fica confirmada, sem ressalvas. Isto em mente, passamos a apresentar nossas conclusões, sempre atentos à desejada concisão.

\section{Primeira conclusão}

Observadas as múltiplas configurações assumidas pelo diferimento nas legislações estaduais do ICMS, parece-nos difícil idear um conceito que as abranja a todas, o que implica pouco provável elaborar uma definição digna de ser aprovada - e, por derradeiro, cogitar de atribuir-lhe tal ou qual natureza jurídica.

Examinado o atual regulamento paulista do ICMS - RICMS/00 -, no qual se cuida de diferimento do lançamento do imposto, findamos por entender que as pertinentes regras (i) não guardam relação com nenhuma espécie de postergação e (ii) o lançamento ao qual se referem não é nada mais do que aquele da incumbência do agente econômico ao qual a Lei $n^{\circ} 6.374 / 89$ imputou o papel de sujeito passivo por substituição no tocante às assim chamadas "operações antecedentes". Tendo em conta esses diagnósticos, parece-nos legítimo concluir que tais regras mostram-se de todo inúteis, o que por sua vez nos leva a pensar que desnecessário conceituar o que seja o diferimento do lançamento constante da legislação paulista do ICMS, bem assim torna irrelevante indagar qual seja sua natureza jurídica.

O entendimento não tem serventia, porém, para os casos nos quais o diferimento do lançamento não se justifica na substituição tributária "para trás" tal como prevista na Lei $\mathrm{n}^{\circ}$ 6.374/89, não serve para dizer nada a respeito de atos administrativos maculados de ilegalidade, tais como os baixados pelo Poder Executivo para, passando ao largo dos limites da Lei n 6374/89, ampliar o rol de mercadorias em relação às quais possível a aplicação da substituição tributária e, por ricochete, atribuir sujeição passiva por substituição a uns tantos ou quantos agentes econômicos, ou para conceder benefícios 
fiscais não previstos em lei formal. Adiantamo-nos um tanto, pois há elementos neste parágrafo que dizem mais diretamente com conclusões formuladas logo adiante. Foi necessário.

\section{Segunda conclusão}

O exame da legislação paulista do ICMS descortina regras que, tocantes ao diferimento do lançamento do imposto, implicam atribuição de sujeição passiva por substituição por meio de diplomas infralegais. Tendo em vista que a atribuição de sujeição passiva, não importa de que tipo seja, é matéria reservada a lei formal, tais regras mostramse tisnadas de ilegalidade.

\section{Terceira conclusão}

Malgrado o entendimento segundo o qual a comodidade e a praticidade animariam a implantação do diferimento no âmbito do ICMS, a legislação paulista do tributo mostra exemplos nos quais se deixou de levar em conta esses objetivos.

\section{Quarta conclusão}

Nada obstante imprescindível acatar o princípio da clareza quando da elaboração de textos normativos, evitando-se o quanto possível dar causa a perplexidades na mente dos que devem conhecê-los - e a eles sujeitar-se -, o estudo da legislação paulista do ICMS no respeitante ao diferimento do lançamento revela exemplos que traduzem exatamente o contrário.

\section{Quinta conclusão}

Observa-se, na legislação paulista do ICMS respeitante ao diferimento do lançamento, a existência de dispositivos que implicam violação ao princípio da livre concorrência consagrado na Constituição Federal de 1988. 


\section{Sexta conclusão}

Examinada a legislação paulista do ICMS, diagnostica-se a existência de diplomas infralegais nos quais se lançou mão do regime de diferimento do lançamento com o propósito de conceder benefícios fiscais. 


\section{REFERÊNCIAS BIBLIOGRÁFICAS}

ABBAGNANO, Nicola. Dicionário de Filosofia. 5. ed. São Paulo: Martins Fontes, 2007.

AMARO, Luciano. Direito Tributário Brasileiro. 15. ed. São Paulo: Saraiva, 2009.

. Lançamento, essa Formalidade! In: TÔRRES, Heleno Taveira (Coord). Teoria

Geral da Obrigação Tributária - Estudos em Homenagem ao Professor José Souto Maior Borges. São Paulo: Malheiros, 2005, p. 374-390.

ATALIBA, Geraldo. Apontamentos de Ciência das Finanças, Direito Financeiro e Tributário. São Paulo: RT, 1969.

. Estudos e Pareceres de Direito Tributário. v. 1. São Paulo: RT, 1978.

; GIARDINO, Cléber. ICM - Linhas Mestras Constitucionais - O Diferimento. Revista de Direito Tributário, São Paulo, n. 23-24, p. 118-145, jan./jun. 1983.

;___ Diferimento do ICM - Cana-de-açúcar em caule - Entidade subjetivamente isenta de ICM quanto a mercadorias de sua própria produção - Substituição tributária. Revista de Direito Tributário. São Paulo, n. 50, p. 81-91, out./dez. 1989.

BASTOS, Celso Ribeiro. Curso de Direito Constitucional. 14. ed. São Paulo: Saraiva, 1992.

. Hermenêutica e Interpretação Constitucional. São Paulo: Celso Bastos/Instituto Brasileiro de Direito Constitucional, 1997.

BECHO, Renato Lopes. Sujeição Passiva e Responsabilidade Tributária. São Paulo: Dialética, 2000.

BECKER, Alfredo Augusto. Teoria Geral do Direito Tributário. 3. ed. São Paulo: Lejus, 2002. 
BONILHA, Paulo Celso Bergstrom. Diferimento e Direito de Crédito do ICM. Ltr Suplemento Tributário, São Paulo, n. 156, p. 681-683, 1979.

. Lançamento do ICM. In: MARTINS, Ives Gandra da Silva (Coord.). Curso de Direito Tributário. São Paulo: Saraiva, 1982, p. 349-356.

. Notas sobre as Deformações da Incidência Plurifásica do ICMS. Direito Tributário Atual, São Paulo, n. 23, p. 402-409, 2009.

BORGES, Arnaldo. O Sujeito Passivo da Obrigação Tributária. São Paulo: RT, 1981.

BORGES, José Souto Maior. A Constitucionalidade do Convênio ICM 07/77 e a Inexistência do Direito de Crédito do Substituto, no Diferimento do ICM. Revista de Direito Tributário, São Paulo, n. 6, ano II, p. 87-100, out./dez. 1978.

. A Isonomia Tributária na Constituição Federal de 1988. Revista de Direito Tributário, São Paulo, n. 64, p. 8-19, s/d.

. Sobre as Isenções, Incentivos e Benefícios Fiscais Relativos ao ICMS. Revista Dialética de Direito Tributário, São Paulo, n. 6, p. 69-73, mar. 1996.

. Revisitando a Isenção Tributária - A Isenção Tributária à Luz da Hermenêutica Histórica. Revista de Direito Tributário, São Paulo, n. 71, p. 24-29, s.d. . Lançamento Tributário. 2. ed. São Paulo: Malheiros, 1999.

BOUVIER, Michel. Introduction au Droit Fiscal Général et à la Théorie de l'Impôt. 8. ed. Paris: LGDJ, 2007.

BRITO, Edvaldo. A Substituição Tributária no ICMS. Revista Dialética de Direito Tributário, São Paulo, n. 2, p. 24-31, 1995.

- ICMS: Inconstitucionalidades da Lei Complementar 87/96. Substituição Tributária. Aplicabilidade do Decreto-Lei 406/68. Revista Dialética de Direito Tributário, São Paulo, n. 16, p. 59-75, jan. 1997. 
Problemas Jurídicos Atuais do ICMS. In: ROCHA, Valdir de Oliveira (Coord.). O ICMS, a LC 87/96 e Questões Jurídicas Atuais. São Paulo: Dialética, 1997, p. 81-117.

BROCKSTEDT, Fernando. O ICM: Impôsto sobre Operações Relativas à Circulação de Mercadorias. Porto Alegre: s. n., 1972.

CAMPILONGO, Paulo Antonio Fernandes. O ICMS e a Antecipação Parcial na Operação Interestadual de Circulação de Mercadorias. In:___(Coord.). ICMS Aspectos Jurídicos Relevantes. São Paulo: Quartier Latin, 2008, p. 51-76.

CANTO, Gilberto de Ulhôa. O Lançamento. In: MARTINS, Ives Gandra da Silva (Coord.). Caderno de Pesquisas Tributárias. São Paulo. v. 12, p. 1-23 (p. 19), 1987.

CARRAZZA, Roque Antonio. ICMS. 14 ed. São Paulo: Malheiros, 2009.

. Lei Complementar $n^{\circ}$ 87/96. In: Lei Complementar $n^{o} 87 / 96$ - Palestras proferidas em 1996 no Tribunal de Impostos e Taxas - TIT. São Paulo: IOB, s/d, p. 73114.

. ICMS - Extensão dos benefícios fiscais previstos no Convênio-ICMS n. 52/1991 e no art. 399 do RICMS-SP (redação originária), às operações mercantis com partes e peças destinadas a permitir que sistemas de irrigação e implementos agrícolas funcionem de acordo com as necessidades dos usuários - possibilidade jurídica - questões conexas. In: CARVALHO, Antonio Augusto Silva Pereira de; FERNÁNDEZ, German Alejandro San Martín (Coords.). Estudos em Homenagem a José Eduardo Monteiro de Barros Direito Tributário. São Paulo: MP, 2010, p. 569-592.

CARVAlHO, Paulo de Barros. Curso de Direito Tributário. 22. ed. São Paulo: Saraiva, 2010.

. Direito Tributário: Fundamentos Jurídicos da Incidência. 8. ed. São Paulo: Saraiva, 2010.

. Direito Tributário, Linguagem e Método. 2. ed. São Paulo: Noeses, 2008. 
CATÃO, Marcos André Vinhas. Regime Jurídico dos Incentivos Fiscais. Rio de Janeiro: Renovar, 2004.

CAVALCANTE, Denise Lucena. Crédito Tributário. São Paulo: Malheiros, 2004.

CHIESA, Clélio. ICMS - Sistema Constitucional Tributário - Algumas Inconstitucionalidades da LC 87/96. São Paulo: LTr, 1997.

COELHO, Inocêncio Mártires. A Defesa da Livre Concorrência na Constituição de 1988. Arquivos do Ministério da Justiça, Brasília, v. 47, n. 184, p. 5-18, jul./dez. 1994.

COÊLHO, Sacha Calmon Navarro. A Natureza Jurídica do Diferimento na Área do ICM. Revista de Direito Tributário, São Paulo, n. 21/22, p. 5-41, jul./dez. 1982.

. Curso de Direito Tributário Brasileiro. 10. ed. Rio de Janeiro: Forense, 2009.

. Estudo sobre a Sujeição Passiva Direta e Indireta no Direito Brasileiro - Escólios para uma Futura Modificação do Código Tributário Nacional - Em Homenagem a Geraldo Ataliba. Revista de Direito Tributário, São Paulo, n. 67, p. 268-278, s/d.

. ICM - Convênios Interestaduais para Isenção - Diferimento - Lesão de Direito Individual. Revista de Direito Tributário. São Paulo, n. 7-8, p. 71-83, jan./jul. 1979.

. Possibilidade de Aproveitamento, pela Geradora, dos Créditos de ICMS pelas Entradas de Insumos e Bens do Ativo Afetados à Produção de Energia Elétrica Vendida com Diferimento. O Caso do Pará. Revista Dialética de Direito Tributário. São Paulo, n. 74, p. 130-143, nov. 2001.

. Teoria Geral do Tributo, da Interpretação e da Exoneração Tributária. 3 ed. São Paulo: Dialética, 2003.

. MANEIRA, Eduardo. A Substituição Tributária Progressiva e a Cobrança de ICMS sobre Eventual Aumento de Volume de Combustível Decorrente da Variação de Temperatura Ambiente. In: COÊLHO, Sacha Calmon Navarro. Direito Tributário - Temas Atuais. São Paulo: Quartier Latin, 2006, p. 347-369. 
COSTA, Alcides Jorge. Contribuição ao Estudo da Obrigação Tributária. São Paulo: IBDT, 2003.

. ICM na Constituição e na Lei Complementar. São Paulo: Resenha Tributária, 1978.

. ICMS e Substituição Tributária. Revista Dialética de Direito Tributário, São Paulo, n. 2, p. 70-95, 1995.

. Lei Complementar $n^{\circ}$ 87/96. In: Lei Complementar $n^{\circ} 87 / 96$ - Palestras proferidas em 1996 no Tribunal de Impostos e Taxas - TIT. São Paulo: IOB, s/d, p. 7-30.

COSTA, Gustavo F. Cavalcanti. O Conflito de Competência Exonerativa em Matéria de ICMS: uma Abordagem Político-Jurídica sobre a "Guerra Fiscal" na Federação Brasileira. Revista Tributária e de Finanças Públicas, São Paulo, n. 42, p. 85-99, jan./fev. 2002.

COSTA, Regina Helena. Praticabilidade e Justiça Tributária Exeqüibilidade de Lei Tributária e Direito do Contribuinte. São Paulo: Malheiros, 2007.

DENARI, Zelmo. Curso de Direito Tributário. 9 ed. São Paulo: Atlas, 2008.

. Sujeitos Ativo e Passivo da Relação Jurídica Tributária. In: MARTINS, Ives Gandra da Silva (Coord.). Curso de Direito Tributário. 11 ed. São Paulo: Saraiva, 2009, p. 171-190.

DERZI, Misabel de Abreu Machado. Não-Cumulatividade, Neutralidade, PIS e Cofins e a Emenda Constitucional $n^{\circ} 42 / 03$. In: ROCHA, Valdir de Oliveira (Coord.). Grandes Questões Atuais do Direito Tributário. São Paulo: Dialética, 2004, v. 8, p. 339-355.

DINIZ, Marcelo de Lima Castro; FORTES, Fellipe Cianca. Incentivos Fiscais no STJ. In: MARTINS, Ives Gandra da Silva; ELALI, André; PEIXOTO, Marcelo Magalhães (Coords.). Incentivos Fiscais: Questões Pontuais nas Esferas Federal, Estadual e Municipal. São Paulo: MP, 2007, p. 265-297. 
FALCÃO, Amílcar de Araújo. Fato Gerador da Obrigação Tributária. 6 ed. Rio de Janeiro: Forense, 1997.

. Introdução ao Direito Tributário. 6 ed. Rio de Janeiro: Forense, 1999.

FERRAGUT, Maria Rita. Responsabilidade Tributária: Conceitos Fundamentais. In: ; NEDER, Marcos Vinicius (Coords.). Responsabilidade Tributária. São Paulo: Dialética, 2007.

. Responsabilidade Tributária e o Código Civil de 2002. São Paulo: Noeses, 2005.

FERRAZ JÚNIOR, Tercio Sampaio. Obrigação Tributária Acessória e Limites de Imposição: Razoabilidade e Neutralidade Concorrencial do Estado. In: FERRAZ, Roberto Catalano Botelho (Coord.). Princípios e Limites da Tributação. São Paulo: Quartier Latin, 2005, p. 715-735

FEYERABEND, Paul. Contre La Méthode - Esquisse d'une Théorie Anarchiste de la Connaissance. Tradução: Baudoin Jurdant e Adnès Schlumberger. Paris: Seuil, 1979.

FONROUGE, Carlos Giuliani. Derecho Financiero. v. 1. Atualização de Susana Camila Navarrine e Rubén Oscar Asorey. 6. ed. Buenos Aires: Depalma, 1997.

FRATTARI, Rafhael. O Diferimento e a Regra do Artigo $8^{\circ}$, Conjugado com o Item 39, Anexo II, do Regulamento Mineiro do ICMS/96. Eficaz Boletim Tributário, Belo Horizonte, n. 39, p. 2-6, 1998.

GIARDINO, Cléber. Relação Jurídica Tributária e o Aspecto Pessoal que a Integra. Revista de Direito Público, São Paulo, n. 25, ano VI, p. 183-195, jul./set. 1973.

GRAU, Eros Roberto. Princípio da Livre Concorrência - Função Regulamentar e Função Normativa. Revista Trimestral de Direito Público, São Paulo, v. 93, n. 4, p. 104-129, 1993.

GRECO, Marco Aurélio. Substituição Tributária (Antecipação do Fato Gerador). 2. ed. São Paulo: Malheiros, 2001. 
GROSCLAUDE, Jacques; MARCHESSOU, Philippe. Droit Fiscal Général. 6. ed. Paris: Dalloz, 2007

GUIMARÃES, Carlos da Rocha. Lançamento - Natureza e Eficácia. In: MARTINS, Ives Gandra da Silva (Coord.). Caderno de Pesquisas Tributárias. São Paulo, vol 12, p. 241$247,1987$.

GUIMARÃES, Ylves José de Miranda. ICM Análise e Princípios Estruturais. São Paulo: LTR, 1975.

GUSMÃO, Paulo Dourado de. Introdução à Ciência do Direito. Rio de Janeiro: Forense, 1960.

HENRIQUES, Elcio Fiori. Os Benefícios Fiscais no Direito Financeiro e Orçamentário. São Paulo: Quartier Latin, 2010

HORVATH, Estevão. Lançamento Tributário e “Autolançamento”. São Paulo: Dialética, 1997.

JANNOTTI, Onaldo Franco. Legitimação da Chamada Substituição Tributária "Para Frente". Revista de Direito Tributário, n. 5, p. 159-178, jul./set. 1978.

JUSTEN FILHO, Marçal. Sujeição Passiva Tributária. Belém: CEJUP, 1986.

LACOMBE, Américo Masset. Obrigação Tributária. São Paulo: RT, 1977. . Lançamento. In: MARTINS, Ives Gandra da Silva (Coord.). Curso de Direito Tributário. 11. ed. São Paulo: Saraiva, 2009

LARANJEIRA, Álvaro Reis (Org.). ICM: Respostas da Consultoria Tributária. São Paulo: LTr, 1978.

LARANJEIRA, Álvaro Reis (Org.). ICM: Respostas da Consultoria Tributária. v. 2. São Paulo: LTr, 1984. 
LEAL, Victor Nunes. Problemas de Direito Público. Rio de Janeiro: Forense, 1960.

MACHADO, Hugo de Brito. Aspectos Fundamentais do ICMS. São Paulo: Dialética, 1997.

. A Substituição Tributária no ICMS. Revista Dialética de Direito Tributário, São Paulo, n. 26, p. 27-37, 1997.

A Substituição Tributária no ICMS e a Lei Estadual. Repertório IOB de Jurisprudência, n. 14, p. 340-342, 1997.

; MACHADO SEGUNDO, Hugo de Brito. ICMS. Substituição Tributária "para Frente”. Operações com Veículos Automotores. Tabelas Nacionais de Preços. Frete. NãoInclusão. Efeitos. Revista Dialética de Direito Tributário, São Paulo, n. 84, p. 151-166, set. 2002.

MARQUES JÚNIOR, Álvaro de Azevedo. O ICM e o Correspondente Crédito na Constituição. Revista de Direito Tributário, n. 21/22, p. 56-77, jul./dez. 1982.

MARTINS, Ives Gandra da Silva. A Técnica de Diferimento da Incidência do ICM Constitucionalidade do Princípio da Não Cumulatividade Quando de sua Adoção. Revista da Procuradoria Geral do Estado de São Paulo. São Paulo, n. 21, p. 169-197, dez. 1983.

MATTOS, Aroldo Gomes de. ICMS - Comentários à Legislação Nacional. São Paulo: Dialética, 2006.

MELO, José Eduardo Soares de. Curso de Direito Tributário. 9. ed. São Paulo: Dialética, 2010. . ICMS: Teoria e Prática. 11. ed. São Paulo: Dialética, 2009.

. ICMS - Base de Cálculo - Descontos, Seguros, Juros, Multas, Correção, Reajustes. Pautas na Substituição Tributária. Importações. Base Reduzida e Estorno de Crédito. In: ROCHA, Valdir de Oliveira (Coord.). Grandes Questões Atuais do Direito Tributário. São Paulo: Dialética, 2006, v. 10, p. 276-301. 
; LIPPO, Luis Francisco. A Não-Cumulatividade Tributária (ICMS, IPI, ISS, PIS e COFINS). 3. ed. São Paulo: Dialética, 2008.

MIRANDA, Jorge. Teoria do Estado e da Constituição. Rio de Janeiro: Forense, 2007.

MIRANDA, Pontes de. Comentários à Constituição de 1967 - Tomo II. 2. ed. São Paulo: RT, 1970.

NABARRETE NETO, André. O Recurso Extraordinário das Decisões que Reconhecem o Direito de Crédito do ICM Diferido. Revista da Procuradoria Geral do Estado de São Paulo, São Paulo, n. 17, p. 257-264, dez. 1980.

NEUMARK, Fritz. Principios de la Imposición. Madrid: Instituto de Estudios Fiscales, 1974.

NOGUEIRA, Ruy Barbosa. Teoria do lançamento tributário. São Paulo: Resenha Tributária, 1973.

PINHO, Alessandra Gondim. Fato Jurídico Tributário. São Paulo: Max Limonad, 2001.

PIRES, Adilson Rodrigues. Ligeiras Reflexões sobre a Questão dos Incentivos Fiscais no Brasil. In: MARTINS, Ives Gandra da Silva; ELALI, André; PEIXOTO, Marcelo Magalhães (Coords.). Incentivos Fiscais: Questões Pontuais nas Esferas Federal, Estadual e Municipal. São Paulo: MP, 2007, p. 15-35.

POLIZELLI, Victor Borges. A Eficiência do Sistema Tributário - Uma Questão de Busca da Justiça com Proteção da Segurança Jurídica. Direito Tributário Atual, São Paulo, v. 20, p. 253-271, 2006.

POPPER, Karl. O Mito do Contexto. Lisboa: 70, 1999. . Em Busca de um Mundo Melhor. São Paulo: Martins, 2006.

RODRIGUES, Walter Piva. Substituição Tributária. São Paulo: Quartier Latin, 2004. 
ROSA, José Roberto. A Substituição Tributária no ICMS e sua Eficácia. In: Congresso Nacional de Estudos Tributários (5: 2008: São Paulo, SP) Direito Tributário Linguagem e Método. São Paulo: Noeses, 2008, p. 467-486.

. Curso de ICMS com o Professor José Rosa. Itu: Ottoni, 2008.

. Substituição Tributária no ICMS: Manual Explicativo. 2 ed. Itu (SP): Ottoni, 2009.

ROTHMANN, Gerd Willi. Tributação, Sonegação e Livre Concorrência. In: FERRAZ, Roberto (Coord.). Princípios e Limites da Tributação 2 - Os Princípios da Ordem Econômica e a Tributação. São Paulo: Quartier Latin, 2009, p. 331-371.

- A Guerra Fiscal dos Estados na (Des)Ordem Tributária e Econômica da Federação. In: CARVALHO, Antonio Augusto Silva Pereira de; FERNÁNDEZ, German Alejandro San Martín (Coord.). Estudos em Homenagem a José Eduardo Monteiro de Barros - Direito Tributário. São Paulo: MP, 2010, p. 333-355.

SANTI, Eurico Marcos Diniz de. Lançamento Tributário. 2. ed. São Paulo: Max Limonad, 2002.

SCAFF, Fernando Facury. Efeitos da Coisa Julgada em Matéria Tributária e Livre Concorrência. In: ROCHA, Valdir de Oliveira (Coord.). Grandes Questões Atuais do Direito Tributário. São Paulo: Dialética, 2005, v. 9, p. 110-135.

. ICMS, Guerra Fiscal e Concorrência na Venda de Serviços Telefônicos PréPagos. Revista Dialética de Direito Tributário, São Paulo, n. 126, p. 70-80, mar. 2006.

SCHOUERI, Luís Eduardo. Livre Concorrência e Tributação. In: ROCHA, Valdir de Oliveira (Coord.). Grandes Questões Atuais do Direito Tributário. São Paulo: Dialética, 2007, v. 11, p. 241-271.

SECRETARIA DE ESTADO DOS NEGÓCIOS DA FAZENDA - Coordenadoria da Administração Tributária. Boletim Tributário, São Paulo, n. 6, p. 419-420 (p. 419), jul 2006. 
SEIXAS FILHO, Aurélio Pitanga. A Responsabilidade Tributária do Exportador de Produto Industrializado pelo ICMS Diferido da Operação Anterior. Revista Dialética de Direito Tributário, São Paulo, n. 8, p. 39-43, mai. 1996.

SILVA, Antônio Pinto da. Lei no 440 de 1974. In: Procuradoria Geral do Estado. Direito Tributário: Conferências, outubro-novembro de 1976. São Paulo: Centro de Estudos da Procuradoria Geral do Estado, p. 179-219, 1977.

. Compatibilidade do Diferimento com o Princípio da Não-Cumulatividade do

I.C.M. Boletim do Centro de Estudos da Procuradoria Geral do Estado, São Paulo, v. 2, n. 17 , p. 591-606, set. 1978.

SILVA, Edgard Neves da; MOTTA FILHO, Marcello Martins. Outras Formas Desonerativas. In: MARTINS, Ives Gandra da Silva (Coord.). Curso de Direito Tributário. 11. ed. São Paulo: Saraiva, 2009, p. 299-318.

SMITH, Adam. Uma Investigação sobre a Natureza e Causa da Riqueza das Nações. São Paulo: Hemus, 1981.

SOUSA, Rubens Gomes de. Compêndio de Legislação Tributária. Edição póstuma. São Paulo: Resenha Tributária, 1981.

. Os Impostos sobre o Valor Acrescido no Sistema Tributário. Revista de Direito Administrativo, Rio de Janeiro, n. 110, p. 17-26, out./dez. 1972.

SOUZA, Fátima Fernandes Rodrigues de. A Não-Cumulatividade no Direito Tributário Brasileiro. In: MARTINS, Ives Gandra da Silva (Coord.). O princípio da nãocumulatividade. São Paulo: Editora Revista dos Tribunais, 2004.

SOUZA, Juraci Altino de. A Técnica do Diferimento na Área do ICMS. Revista da Procuradoria Geral do Estado de São Paulo, São Paulo, n. 39, p. 32-47, junho 1993.

TIPKE, Klaus; LANG, Joachim. Direito Tributário. v. 1. Tradução da 18. ed. alemã por Luiz Dória Furquim. Porto Alegre: Sergio Antonio Fabris, 2008. 
TÔRRES, Heleno Taveira. Funções das Leis Complementares no Sistema Tributário Nacional - Hierarquia de Normas - Papel do Código Tributário Nacional no Ordenamento. Revista de Direito Tributário, São Paulo, n. 84, p. 50-69, 2002.

- ICMS e Regimes Especiais de Tributação na Venda de Combustíveis Diferimento, Substituição e Cassação de Inscrição Estadual nos Casos de Adulteração. In: CAMPILONGO, Paulo Antonio Fernandes (Coord.). ICMS: Aspectos Jurídicos Relevantes. São Paulo: Quartier Latin, 2008, p. 123-187.

TORRES, Ricardo Lobo. O Princípio da Isonomia, os Incentivos do ICMS e a Jurisprudência do STF sobre a Guerra Fiscal. In: MARTINS, Ives Gandra da Silva; ELALI, André; PEIXOTO, Marcelo Magalhães (Coords.). Incentivos Fiscais: Questões Pontuais nas Esferas Federal, Estadual e Municipal. São Paulo: MP, 2007, p. 327-345.

. Substituição Tributária e Cobrança Antecipada do ICMS. In: ROCHA, Valdir de Oliveira (Coord.). ICMS - Problemas Jurídicos. São Paulo: Dialética, 1996, p. 185-202.

. Tratado de Direito Constitucional Financeiro e Tributário - Valores e Princípios Constitucionais Tributários. v. II. Rio de Janeiro: Renovar, 2005.

. Conflitos de Competência e Guerra Fiscal. In: Congresso Nacional de Estudos Tributários (5: 2008: São Paulo, SP) Direito Tributário Linguagem e Método. São Paulo: Noeses, 2008, p. 825-847 (p. 827).

. Tratado de Direito Constitucional Financeiro e Tributário. Os Tributos na Constituição. v. IV. Rio de Janeiro: Renovar, 2007.

TRIBUNAL DE IMPOSTOS E TAXAS DA SECRETARIA DA FAZENDA DO ESTADO DE SÃO PAULO. Ementário do TIT - 2003. São Paulo: Secretaria da Fazenda do Estado de São Paulo, 2003.

VILLEY, Michel. Réflexions sur la Philosophie et le Droit - Les Carnets. Paris: PUF, 1995. 
XAVIER, Alberto. Do Lançamento: Teoria Geral do Ato, do Procedimento e do Processo Tributário. 2. ed. Rio de Janeiro: Forense, 2001. 